\title{
Quaternary Geology of the
}

\section{Smoke Creek-Medicine}

\section{Lake-Grenora Area}

\section{Montana and North Dakota}

By IRVING J. WITKIND

G E O L O G I C A L S U R VEY .B U L L E T I N 1073

A study of the Quaternary geology of part of northeastern Montana and northwestern North Dakota

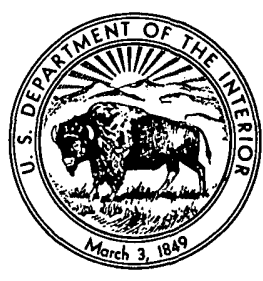




\section{UNITED STATES DEPARTMENT OF THE INTERIOR}

FRED A. SEATON, Secretary

\section{GEOLOGICAL SURVEY}

Thomas B. Nolan, Director

The U. S. Geological Survey Library has cataloged this publication as follows:

\section{Witkind, Irving Jerome, 1917-}

Quaternary geology of the Smoke Creek-Medicine LakeGrenora area, Montana and North Dakota. Washington, U. S. Govt. Print. Off., 1958.

v, 80 p. illus., maps (1 col.) diagrs. $25 \mathrm{~cm}$. (U. S. Geological Survey. Bulletin 1073)

Part of illustrative matter folded in pocket.

Bibliography : p. 76-78.

1. Geology, Stratigraphie-Quaternary. 2. Geology-Montana. 3. Geology-North Dakota. I. Title. II. Title: Smoke Creek-Medicine Lake-Grenora area, Montana and North Dakota. (Series)
QE75.B9 no. 1073 Copy 2.
551.79
G S 58-221
QE696.W5 


\section{CONTENTS}

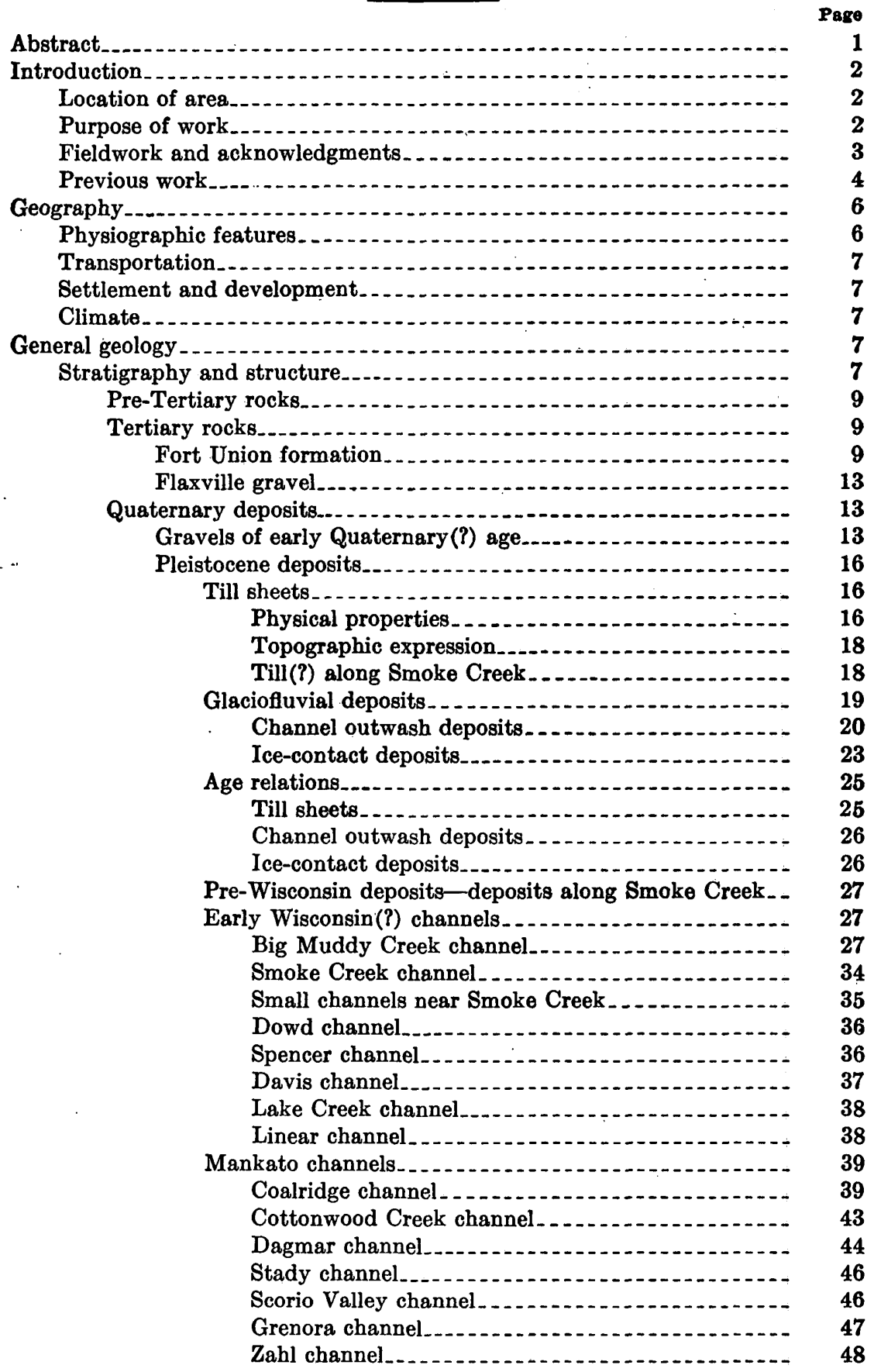


General geology-Continued

Stratigraphy and structure-Continued

Quaternary deposits-Continued

Pleistocene deposits-Continued

Early Wisconsin(?) ice-contact deposits..............

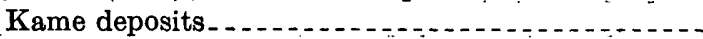

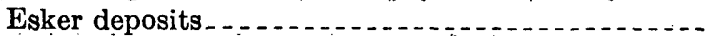

Crevasse deposits and till ridges..............

Mankato ice-contact deposits ..........................

Kame-terrace deposits................................

Kame deposits ........

Esker deposits . .

Crevasse deposits and till ridges............. 53

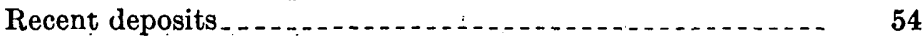

Geologic history

Pre-Pleistocene._.

Pleistocene............... 56

Pre-Wisconsin(?)

Deposits along Smoke Creek...... 57

Ancestral Missouri River. . . .

Early Wisconsin(?)

Middle Wisconsin(?) .

Late Wisconsin (Mankato, substage)

Recent......... 62

Mineral resources....... 63

Coal

Sodium sulfate............ 63

Location of deposits . . 64

Northwestern North Dakota._._.

Grenora Lake 1._. 65

Grenora Lake 2 .

Stink Lake......... 66

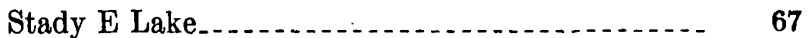

Twin Lakes....... 67

Other small lakes................. 67

Northeastern Montana ......................... 67

Brush Lake saline slough. .................... 68

Horseshoe Lake. . . .

Slough in sec. 6, T. 32 N., R. 59 E._. 68

Slough west of Horseshoe Lake _...

Slough in sec. 2, T. 33 N., R. 58 E........... 69

Slough in sec. 2, T. 34 N., R. 58 E........... 69

Localization of deposits . _.

Field relations...... 71

Older hypotheses of localization

Hypothesis of present work

Construction materials......

Fort Union formation. 75

Sand and gravel... 75

Riprap

Water resources...... 75

References.........

Index 


\section{ILLUSTRATIONS}

Plate 1. Geologic map of the Smoke Creek-Medicine Lake-Grenora area . . . . . .

2. Slump deformation of the Fort Union formation........ Facing 11

3. Area of geophysical exploration . . ............. In pocket

4. Extent of lobate mass of Mankato ice............. In pocket

5. Cross section of the Big Muddy Creek valley in T. 28 N., R. 55 E., Montana........ In pocket

6. Contact between gravel of outwash channel and overlying till. . - . . . . Facing 43

7. Broad, uneven crest of an esker. . . . . . . . . . . Facing 54

8. Linear till ridge with concentration of glacial boulders on its surface... . . . . . Facing 55

9. Salt encrustations along shores of saline slough........ Facing 70

10. Small saline slough . . . . . . . . . . . 71

Figure 1. Map of northeastern Montana and northwestern North Dakota

2. Index map showing relation of Smoke Creek-Medicine LakeGrenora area to areas discussed in previous reports

3. Sketch map showing location of Smoke Creek-Medicine LakeGrenora area with respect to major structural features of eastern Montana and western North Dakota

4. Stratigraphic relations and nomenclature of the Fort Union formation in Montana and North Dakota .............

5. Graphic comparison of pebble counts for gravels and tills in eastern Montana and western North Dakota

6. Stratigraphic section showing tills along Smoke Creek

7. Three stages in development of till-surfaced valleys.........

8. Index map of glacial channel outwash deposits ............

9. Drill holes and their logs in the Scorio Valley channel.......-

10. Terraces of two ages along Big Muddy Creek channel........

11. Four stages in the development of the Antelope sag-........

12. Relation of ancestral Big Muddy channel to present valley----

13. Cross section of preglacial valley north of Froid, Mont.....-

14. Three stages in the development of the Coalridge channel.---

15. Three stages in the development of kame terraces along Cottonwood Creek

16. Sketch map showing area presumably traversed by Missouri River during the Tertiary . . . . . . . . . . . . . . .

17. Isopach map of Grenora Lake 2 sodium sulfate deposit.......

18. Sketch map showing relation of saline lakes to glacial channels.

19. Geologic setting of sodium sulfate deposits in northeastern Montana and northwestern North Dakota...............

\section{CHART}

Physical characteristics of the geologic units that pertain to engineering 



\title{
QUATERNARY GEOLOGY OF THE SMOKE CREEK- MEDICINE LAKE-GRENORA AREA, MONTANA AND NORTH DAKOTA
}

\author{
By Irving J. Witkind
}

ABSTRACT

The Smoke Creek-Medicine Lake-Grenora area includes about 1,800 square miles in northeastern Montana and northwestern North Dakota between the Canadian border and the Missouri River.

A long, shallow topographic trough that is now preserved as a dissected upland trends northeastward across the area. The floor of this trough descends from an altitude of about 2,102 feet at the north end to 1,912 feet at the south end where it joins the Missouri River valley. The ground rises east and west from the axial line of the trough. To the west the ground surface consists of a relatively even till-surfaced upland with a maximum altitude of about 2,600 feet. The east half of the area, at an altitude of about 2,100 feet, contains numerous undrained depressions, many of which are occupied by lakes, marshes, and swamps. In the southern part of the area the present valley floors have been cut well below the floor of the trough; this dissection is not so pronounced in the north.

The exposed rocks include the continental Fort Union formation of Paleocene age, the Flaxville gravel of Miocene or Pliocene age, and surficial deposits of Pleistocene age. The Fort Union formation underlies the entire area, although a complete section is nowhere exposed. This formation consists largely of lightcolored siltstone, claystone, and sandstone in which discontinuous beds of lignite occur. Where the lignite has burned, the overlying claystone and siltstone have been baked to a cherry-red clinker. In this area, which lies on the northwest flank of the Williston structural basin, the strata dip southeast at about 20 feet to the mile. Little is known about the subsurface attitude of these and underlying beds. Fracturing may be indicated by a remarkably straight, 21-mile-long northeastward-trending channel just north of Froid, Mont.

The Flaxville gravel, above the Fort Union formation, crops out along the west edge of the area. Where observed within this area, it is 10 to 20 feet thick, although a maximum thickness of 100 feet has been given in other reports. The gravel consists of well-rounded pebbles of quartz, quartzite, and chert, all rust brown, in a matrix of fine sand. The average pebble is about 1 inch long.

The ancestral Missouri River is presumed to have traversed this area during late Tertiary and early Pleistocene time. If so, it flowed northeastward and its course extended from near Poplar to a point near Grenora, N. Dak. For most of its length the projected course of the river is about 125 feet above the upland.

Continental ice sheets probably overrode part of the area at least 3 times, and perhaps 4, during the Pleistocene. The resulting debris includes till and 
stratified sand and gravel. In places the bedded deposits lie on the till in the form of ice-contact features. Elsewhere, outwash sand and gravel fill broad channels that traverse the till-surfaced uplands. The thickness of fill in most of the channels is unknown; drill holes in the Big Muddy Greek valley have penetrated 185 feet of drift above bedrock; this is probably close to the maximum thickness. Many of the pebbles in these deposits were derived from the Canadian Shield or adjacent to it; limestone and dolomite types predominate. The size ranges from fine sand to boulders 2 feet in. diameter. The average pebble diameter is about half an inch.

An exposure of well-indurated till(?) along Smoke Creek may represent deposits of a pre-Wisconsin ice sheet. On the basis of pebble counts, differences in topographic expression, and by extrapolation from adjacent areas, three till sheets have been mapped. Most of the western part of the area is covered by till that is considered to be of early Wisconsin(?) age. A small area in the eastern part, south of Cottonwood Creek and west of Little Muddy Creek, may be covered by till of middle Wisconsin(?) age. The greater part of the eastern half, however, is covered by till of Mankato age. Ice-contact deposits of early Wisconsin (?) and Mankato ages have been mapped.

The ice-contact deposits include eskers, kames, kame terraces, crevasse fillings, and small deposits of indefinite form. The materials are similar to those in the outwash, but they are not so well sorted.

Economic resources include deposits of lignite, glauber salt, sand and gravel, and glacial boulders suitable for riprap. The sodium sulfate deposits are confined to elongate shallow basinlike depressions within the glacial drift. The alinement of the deposits, many of which are linear, suggests some form of glacial control, probably ice-marginal channels now buried beneath till. Saline ground water moved through the buried channel outwash and broke through to the surface as springs in these till-surfaced depressions. In time, intermittent saline lakes were formed, confined in the basins by the impermeable till. Evaporation increased the salinity of the lakes, and eventually sodium sulfate was deposited.

\section{INTRODUCTION}

\section{LOCATION OF AREA}

The area covered in this report includes parts of Sheridan and Roosevelt Counties in northeastern Montana and parts of Divide and Williams Counties in northwestern North Dakota, parallel to the eastward-flowing Missouri River. Eight 15-minute and three 71/2minute quadrangles were mapped, encompassing about 1,800 square miles (fig. 1). The geologic mapping was undertaken as part of the Missouri-Souris project in the Missouri River Basin development program of the Department of the Interior.

\section{PURPOSE OF WORK}

In general, the area to be mapped was determined by the requirements of the U. S. Bureau of Reclamation, which needed a geologic map of the general area surrounding proposed dam sites and the intended irrigation areas. Most of the problems of engineering geology in this area stem from concealment of a preexisting dissected land 


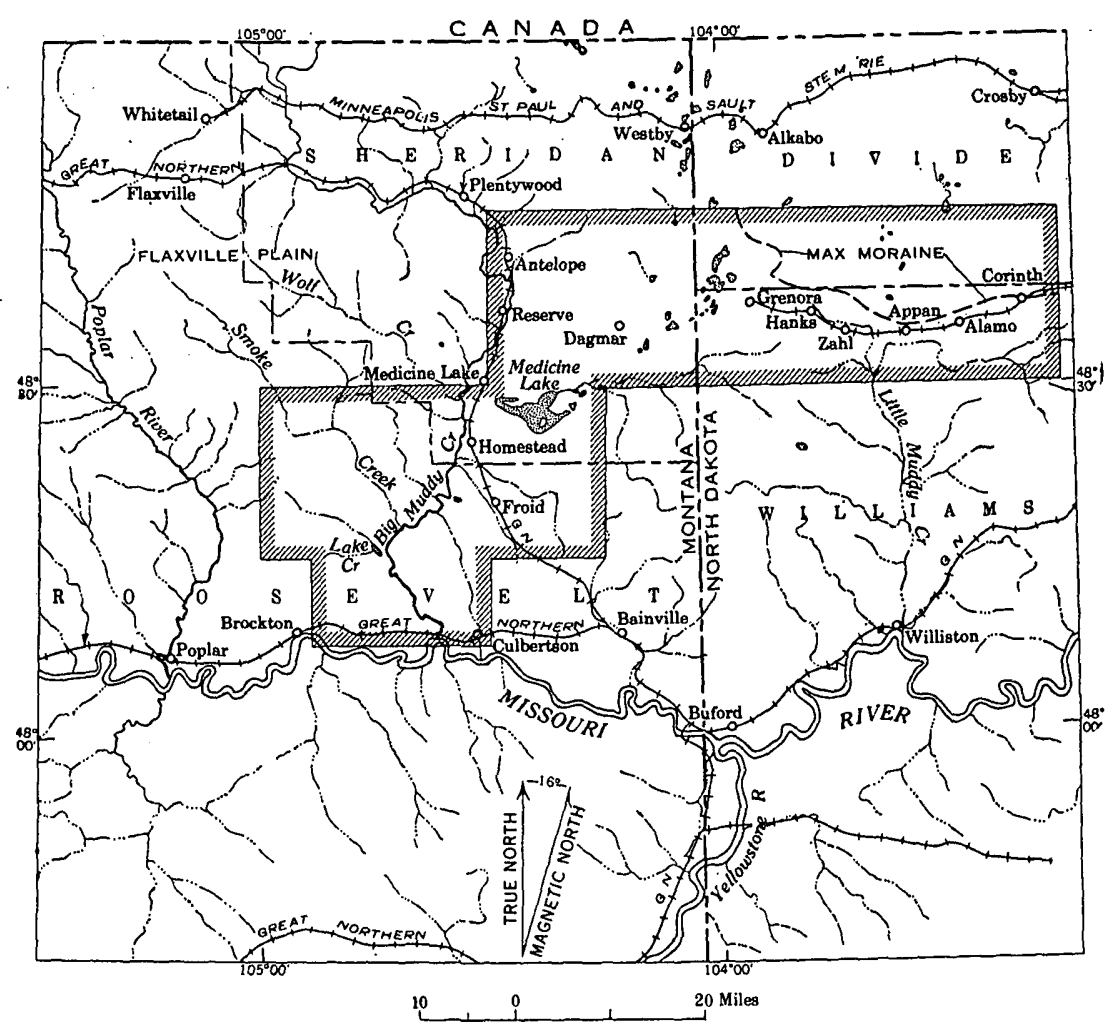

Figore 1.-General map of northeastern Montana and northwestern North Dakota. The Smoke Creek-Medicine Lake-Grenora area is within the sector bounded by hachures.

surface by glacial drift. Numerous buried former river channels assume particular. importance because of possible leakage from reservoirs. Thus, the investigation also contributed to a better understanding of the glacial history.

\section{FIELDWORK AND ACKNOWLEDGMENTS}

Fieldwork was begun in the spring of 1946, continued during the summer. of 1947, and was completed in 1948. The work was begun and supervised for the major part by G. B. Gott. In 1948 Gott was transferred, and I completed the remaining fieldwork. This report represents the efforts of many geologists and is a synthesis and interpretation of their results.

The maps were done originally on aerial photographs at a scale of $1: 20,000$. The information was later transferred to $1: 24,000$ planimetric maps compiled by the Topographic Division of the U. S. Geological Survey. The Kermit No. 3 (Lindvall and Hansen, 1947), 
Zahl No. 4 (Gott and others, 1947), Zahl No. 3 (Lindvall and Hansen, 1948) and Homestead quadrangles (pl. 1) were mapped in the summer of 1946 by Gott, R. M. Lindvall, W. R. Hansen, and J. H. Smith; C. E. Prouty, during the same period, mapped and compiled most of the areal geology of the Homestead quadrangle (pl. 1). C. A. Kaye studied the engineering aspects of the Homestead quadrangle and prepared an engineering-geology map. The Dagmar No. 4, Dagmar No. 3, Bainville No. 2, Smoke Creek, Blair NE, Blair NW, and Brockton NE quadrangles (pl. 1) were partly completed during the summer of 1947 by Gott, R. E. Basile, and myself; I completed that mapping during the summer of 1948 . In the course of the project, R. H. T. Dodson, R. W. Osterstock, and Sol Meltzer served as field assistants during the summer months.

I am particularly grateful to A. D. Howard, who was primarily responsible for acquainting me with the complexities of continentalglacier deposits. Acting as adviser and consultant, Howard participated in the solution of many complex field problems and, further, has criticized this report during its various stages. Many helpful field conferences were held with R. W. Lemke, who had general charge of the work of the Geological Survey's Missouri-Souris project. Ground-water investigations of the area about Medicine Lake were carried out by R. C. Vorhis and E. A. Busch; numerous conferences with them were invaluable to me.

Geologists of the Bureau of Reclamation were very cooperative. H. C. Kirchen, at that time regional geologist of the Montana and North Dakota region, furnished the logs of the Bureau of Reclamation test holes.

Geophysical work to determine the character and extent of the buried channels which interlace this area was completed during the summer of 1948 by George Edwards (1951) under the supervision of H. C. Spicer of the Geophysics Branch of the Geological Survey.

\section{PREVIOUS WORK}

Although the geology of this sector of Montana and North Dakota had never been mapped in detail, several geologists had studied it in connection with other problems. Much of the early physiographic work involving the regional geology of Montana was done by W. C. Alden (1932), and a considerable part of the detailed coal studies was completed by A. L. Beekly (1912) and C. M. Bauer (1912). A report on the Cenozoic history of northeastern Montana and northwestern North Dakota, with emphasis on the Pleistocene, is in preparation by A. D. Howard. Figure 2 shows the relation of this area to nearby areas. 


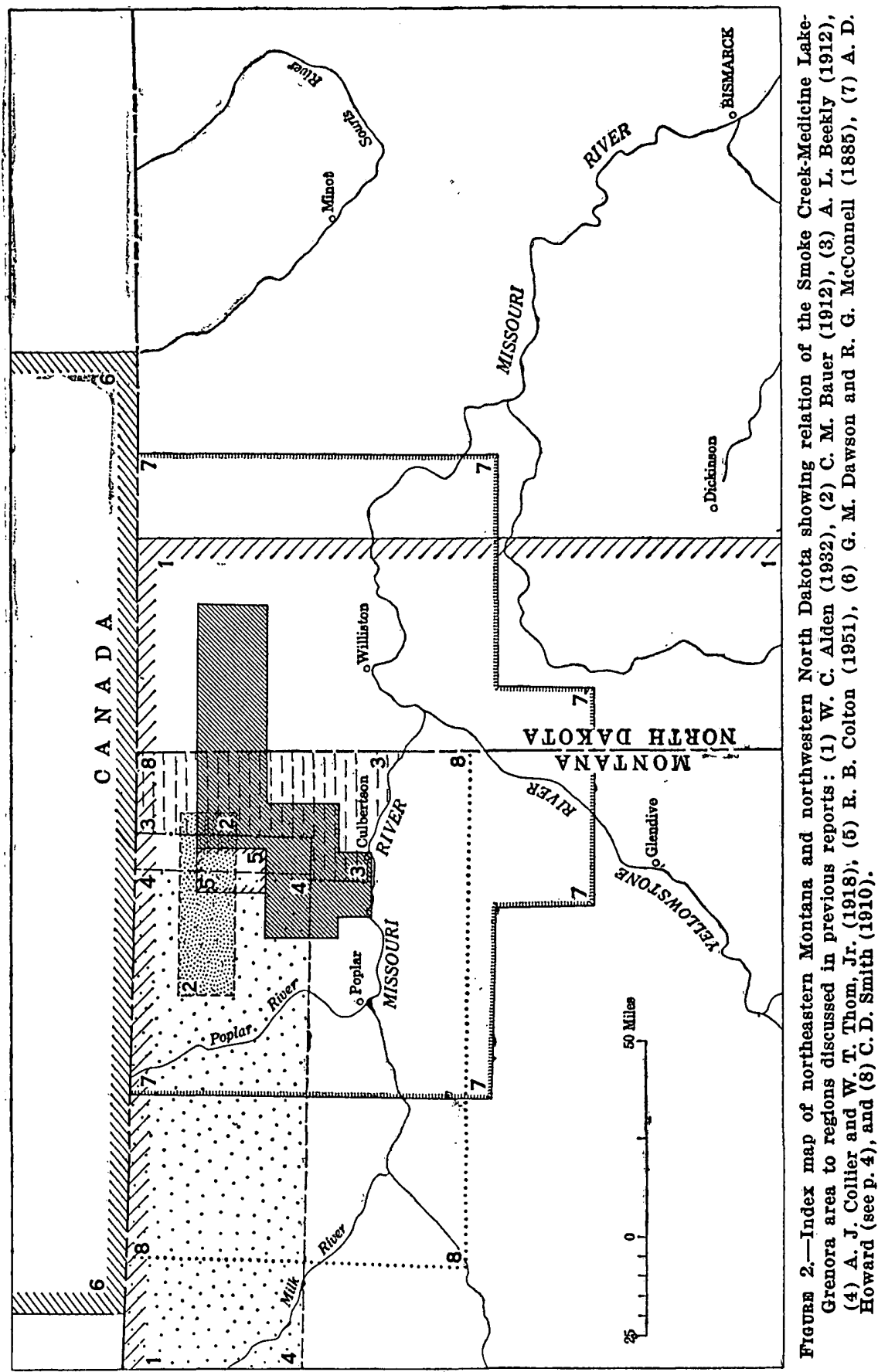




\section{GEOG-RAPHY}

\section{PHYSIOGRAPHIC FEATURES}

The dominant physiographic feature of the Smoke Creek-Medicine: Lake-Grenora area is a long, shallow, dissected topographic trough that trends northeastward across most of the area. Along the west side, the trough is terminated abruptly by the dissected edge of the Flaxville Plain (fig. 1)... East of the axial line of the trough the ground rises gradually to the crest of a northwestward-trending series of morainic hills known as the Altamont or Max moraine (Townsend and Jenke, 1951). The floor of the trough descends from an altitude of about 2,102 feet at its northeast end to 1,912 feet at its south end, where the trough joins the Missouri River.

The floor of the trough appears remarkably accordant when viewed from a distance. In detail, however, low hills rise above the floor, and shallow. valleys have been cut into it. Most of the major streams in and adjacent to this area flow southward and southeastward to the Missouri Rivèr.' 'The Missouri, 'which is the principal stream, flows eastward along the south edge of the area and drains this part of the glaciated Missouri Plateau. The two major tributaries are Big Muddy Creek, whïh joins the Missouri River near Culbertson, Mont., and Little Muddy Creek, which joins it near Williston, N. Dak. Neither of these tributaries is large, and their discharge is scant.

The total relief in the area does not exceed 700 feet. The lowest point, 1,912 feet, is on the flood plain of the Missouri River, and the highest, 2,600 feet, is on the upland west of Smoke Creek. The floors of the major valleys are generally about 100 feet below the adjacent upland.

Practically the entire area is mantled with deposits from continental ice sheets. The uplands are covered with till, and the major valleys, eroded by melt water from wasting ice, are nearly filled with glaciofluvial outwash. Only along the walls of these valleys is bedrock exposed. Now only small, shallow streams flow in these broad valleys. Normally these streams are perennial; during periods of drought, however, they become intermittent.

The east half of the area is characterized by knob and kettle topography. Numerous lakes and marshes are present, and an integrated drainage system is lacking. Two types of lakies are present: freshwater lakes relatively free of salines, and saline (principally sodium sulfate) lakes. West of Medicine Lake the topographiy is more subdued. The drainage patterns are integrated, few closed. depressions are found, and the glaciofluvial deposits are either much dissected or are thickly mantled with alluvium. 
TRANSPORTATION

Most of the area has adequate railroad and highway facilities (pl. 1). The main line of the Great Northern Railway follows the north bank of the Missouri River and two branch lines of this rail. road cross other parts of the region.

Transcontinental U. S. Highway 2, an all-weather oil-surfaced twolane modern highway, traverses the south edge of the area, parallel to the main line of the Great Northern Railway.

\section{SETTLEMENT AND DEVELOPMENT}

The communities within the area have populations of about 500 or less. Plentywood, with a population of about 3,000 , is the largest town near the area.

Most agriculture is of the dry-farming type; wheat is the major crop. The east half of the area is used primarily for raising of wheat, flax, rye, and other grains and has developed into a major wheat-farming district. The west half is used principally for-grazing cattle and sheep.

\section{CLIMATE}

Annual precipitation is about 12.7 inches a year;: most of it falls during late winter and early spring. The mean temperature for the region is about $37^{\circ} \mathrm{F}$. Winters are severe, and temperatures as low as $-20^{\circ} \mathrm{F}$. are not unusual. Summer temperatures may reach $110^{\circ} \mathrm{F}$. and continue for several days. Winds are normally from the west and northwest.

\section{GENERAL GEOLOGY}

\section{STRATIGRAPHY AND STRUCTURE}

Sedimentary rocks of both Tertiary and Quaternary age are exposed in this area and probably rest on Mesozoic and Paleozoic rocks. Most of the Tertiary deposits are concealed beneath a layer of glacial drift, which ranges from a thin film to a cover more than 100 feet thick; bedrock crops out only along valley walls. The Tertiary rocks consist of continental sedimentary deposits of Paleocene age (Fort Union formation) unconformably overlain by unconsolidated gravel (Flaxville gravel) of Miocene or Pliocene age.

The Smoke Creek-Medicine Lake-Grenora area lies across the northwest edge of the Williston basin (fig. 3). The Fort Union strata dip about 20 feet to the mile, generally southeastward. The Williston basin is an elongate northwestward-trending trough with its deepest part in McKenzie and Dunn Counties, N. Dak. (Ballard, 


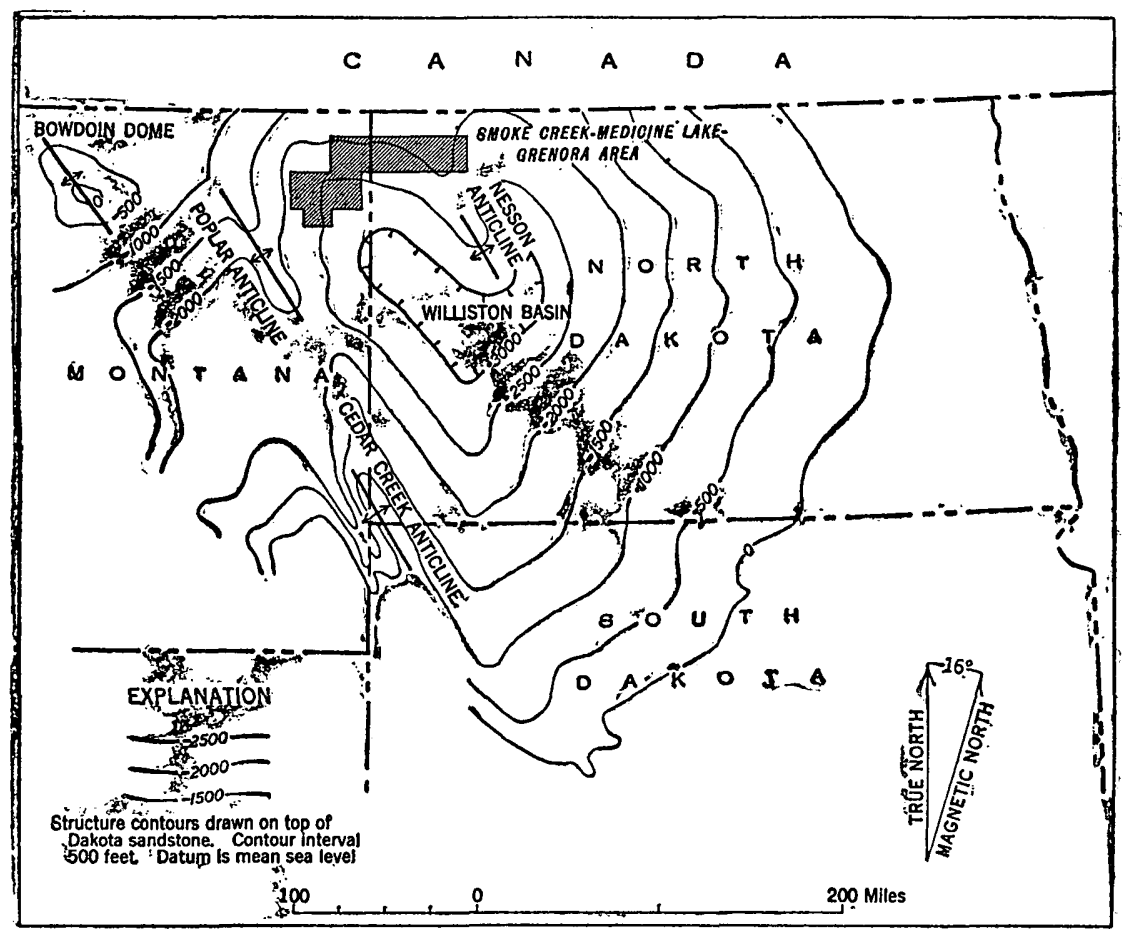

Frgorn 3.-Sketch map showing the location of the Smoke Creek-Medicine Lake-Grenora area with respect to the major structural features of eastern Montana and western North Dakota. (Structure-contour base map from Ballard, 1942, p. 1568.)

1942). Anticlines adjacent to this area include the Poplar anticline in Roosevelt and Richland Counties, Mont.; the Nesson anticline in Williams County, N. Dak.; the Bowdoin dome in Phillips and Blaine Counties, Mont.; and the Cedar Creek anticline in Dawson, Wibaux, and Fallon Counties, Mont. All of these folds trend northwestward, parallel to the Williston basin. The northeast limb of the Poplar anticline is in the southwest corner of the Smoke Creek-Medicine Lake-Grenora area (Thom and Woodring, 1921).

Extending across the northern part of this area is a northwestwardtrending ridge capped by morainal debris. In places the topographic prominence of the moraine may be due to a bedrock core (Howard, Gott, and Lindvall, 1946, p. 1204; Townsend and Jenke, 1951, p. 851). Near Alkabo, N. Dak. (fig. 1), in sec. 22, T. 162 N., R. 102 W., coal-bearing Fort Union strata and a layer of Flaxville gravel(?) crop out beneath till near the crest. Bedrock is also close to the surface elsewhere along the ridge. The extent of the bedrock core is unknown, although it is believed to be discontinuous.

This high, previously referred to as the Altamont terminal moraine, was renamed the Max moraine by Townsend and Jenke 
(1951). In essence, Townsend and Jenke felt that earlier workers incorrectly correlated those deposits properly called Altamont (from exposures near the town of Altamont, S. Dak.) with other much more extensive morainal deposits. The final result was the widespread use of the name Altamont for morainal debris that extends far into North Dakota. They considered this usage erroneous, and suggested that the name Max moraine be applied to the morainal deposits capping the ridge. The usage suggested by Townsend and Jenke is followed here.

This northwestward-trending ridge underlying the Max moraine is puzzling. It may reflect a buried structural feature, as Townsend (1950) reports slight local deformation along the base of the north end of the ridge.

\section{PRE-TERTIARY ROCKS}

Information concerning the pre-Tertiary rocks of northwestern North Dakota and northeastern Montana has been accumulating rapidly since 1949. Many data have been compiled and published by Laird and Towse (1951). The nearest deep drill hole of which a published $\log$ is available (Laird, 1946) is the California Co. Kamp No. 1 in Williams County, N. Dak., in the NW1/4NE1/4 sec. 3, T. 154 N., R. $96 \mathrm{~W}$. This drill hole is about 65 miles southeast of Medicine Lake. The well, drilled to a depth of 10,281 feet to test the Nesson anticline (fig. 3), passed through 800 feet of Tertiary strata, 3,820 feet of Cretaceous, 900 feet of Jurassic, 970 feet of Triassic, 3,160 feet of Mississippian, and 631 feet of Devonian.

\section{TERTIARY ROCKS}

\section{FORT UNION FORMATION}

Meek and Hayden (1862, p. 433) assigned the name Fort Union formation to the sequence of sedimentary rocks that crops out along the banks of the Missouri River near the site of old Fort Union, about 35 miles southeast of Medicine Lake. The small town of Buford, N. Dak., (fig. 1), in T. 152 N., R. 105 W., is a few miles east of the site. Impressed by the many lignite beds exposed, they suggested an alternate, more descriptive name, the Great Lignite group. This name has since been abandoned.

In most of Montana the Fort Union formation of Paleocene age has been subdivided into three members (fig. 4) : the Tullock member, the lowest and oldest, overlain in ascending order by the Lebo shale member and the Tongue River member. In western North Dakota, however, the Fort Union formation consists of the Ludlow (equivalent to the Tullock and Lebo members of Montana), the Tongue River, and the Sentinel Butte shale members. In the area described in this report it was not possible to subdivide the Fort Union formation. Most of 


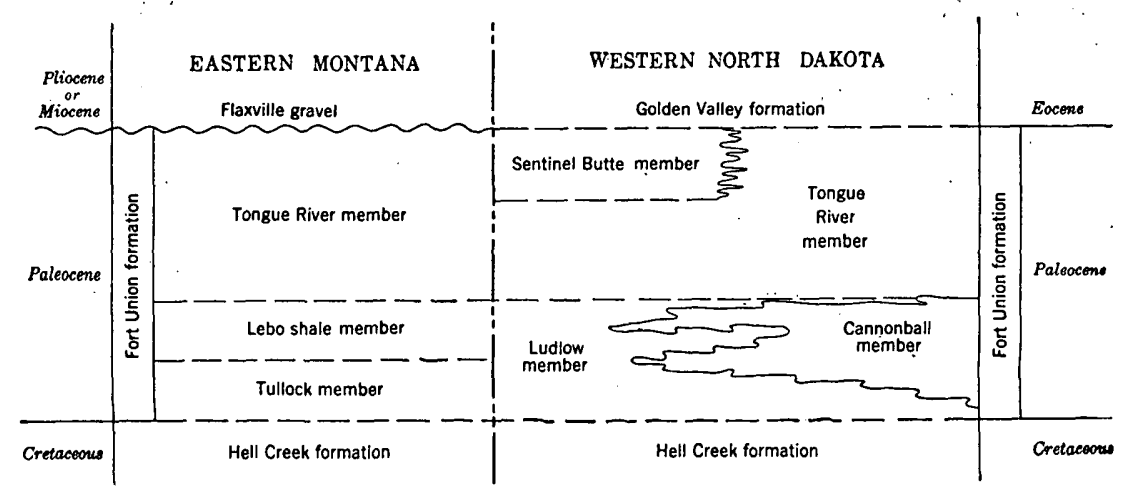

FIgURe 4.- Stratigraphic relations and nomenclature of the Fort Union formation in Montana and North Dakota.

the Fort Union outcrops are believed to be part of the Tongue River member, but this is not certain.

The exposed strata differ widely in color and composition. In general, they consist of yellow or light-buff sandstone, siltstone, and claystone beds irregularly interbedded with darker carbonaceous seams

Generalized stratigraphic section of the Tertiary formations exposed in the Smoke Creek-Medicine Lake-Grenora area, Montana and North Dakota

\begin{tabular}{|c|c|c|c|c|}
\hline Period & Epoch & Formation & Description & $\begin{array}{l}\text { Thick- } \\
\text { ness } \\
\text { (feet) }\end{array}$ \\
\hline \multirow[b]{2}{*}{ Tertiary } & $\begin{array}{l}\text { Miocene or } \\
\text { Pliocene }\end{array}$ & \multirow{2}{*}{ Unconformity } & $\begin{array}{l}\text { Silt, sand, and brown fluvially deposited well- } \\
\text { rounded gravel, generally unconsolidated, but } \\
\text { locally cemented by lime. Considerahle cross- } \\
\text { bedding. Three lithologic rock types make up } \\
\text { this gravel: quartzite (about 66 percent), quartz } \\
\text { (about } 20 \text { percent), and chert (about 14 percent). } \\
\text { Interstices are filled with silt and fine- to } \\
\text { medium-grained sand. Sand lenses are inter- } \\
\text { spersed throughout the gravel. Pebble size } \\
\text { ranges from } 1 / 4 \text { of an inch to } 8 \text { inches. Average } \\
\text { outcrop of gravel layer in this area is } 10 \text { feet } \\
\text { thick, although it may increase to } 20 \text { feet or thin } \\
\text { to } 6 \text {-inch seams before lensing out. Fossils of } \\
\text { Miocene or Pliocene age are present. }\end{array}$ & $1-20 \pm$ \\
\hline & Paleocene & & $\begin{array}{l}\text { Claystone, calcareous siltstone, and sandstone } \\
\text { ranging from blue-gray to buff and yellow. The } \\
\text { coarse- and fine-grained facies interfinger grada- } \\
\text { tionally. Light-colored sediments alternate at } \\
\text { irregular intervals with dark shales, carbona- } \\
\text { ceous seams, and lignite beds. None of the } \\
\text { color bands are persistent. Ferruginous limy } \\
\text { concretions of siltstone and sandstone, varying } \\
\text { in shape and size, are disseminated hetero- } \\
\text { geneously throughout the formation. Most } \\
\text { lignite beds are black on fresh exposure. They } \\
\text { vary in thickness and many are too thin or } \\
\text { lenticular for commercial exploitation. Several, } \\
\text { however, are economically valuable and are } \\
\text { being mined. Impurities in the lignite are } \\
\text { normally pyrite, marcasite, and gypsum. In } \\
\text { several localities, lignite beds have burned, } \\
\text { baking the overlying clay to a hard indurated } \\
\text { clinker, known locally as "scoria." The thick- } \\
\text { ness and degree of fusion of this clinker bed is } \\
\text { some indication of the former thickness of the } \\
\text { lignite bed prior to ignition. }\end{array}$ & $2,000+$ \\
\hline
\end{tabular}




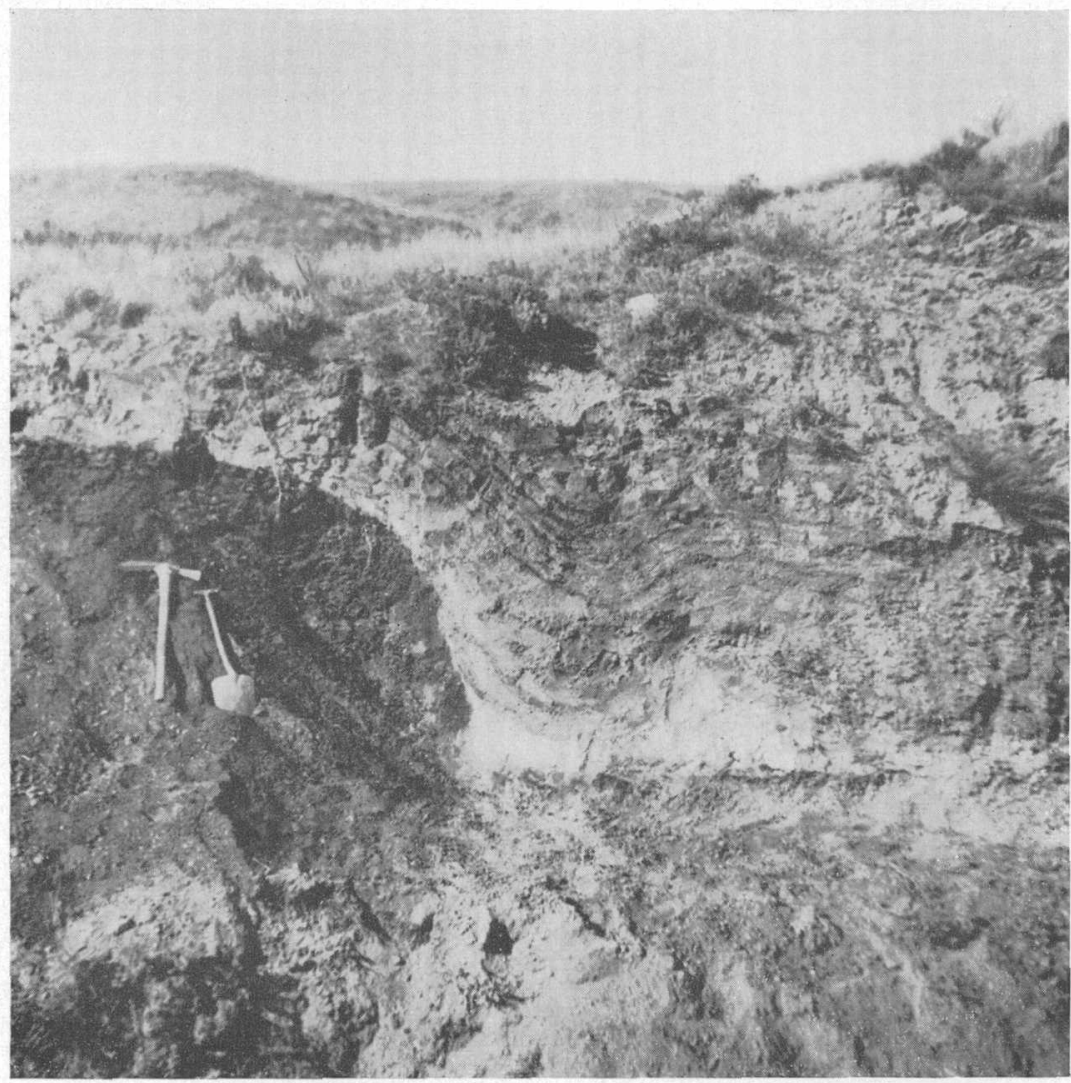

SLUMP DEFORMATION OF THE FORT UNION FORMATION

Slump deformation of the claystone and siltstone beds of the Fort Union as a result of partial burning of a lignite bed (North Dakota, center of sec. 27, T. 159 N., R. 101 W.). The pick and shovel are on a 6 -foot. thick bed of lignite. The white horizontal seam to the right of the dark lignite mass is a bed of ash about 6 inches thick. The overlying clay and silt have been lowered and distorted by slumping. (Photograph by R. M. Lindvall.) 
and lignite beds which are generally thin and discontinuous. On fresh surfaces the sandstone, siltstone, and claystone beds are light gray. Because of their poor cohesion, most of the beds are easily eroded. They change texture laterally and intertongue; in many localities the exposed sandstone and siltstone lenses show excellent crossbedding. Scattered heterogeneously throughout the formation are lime-cemented ferruginous concretions of silt and sand. These concretions are as much as 30 feet long and assume a variety of shapes, although cylinderlike forms predominate.

The lignite beds also vary widely in short distances, both in thickness and composition. The maximum thickness observed is 15 feet. The beds range from brownish black to black. On fresh surfaces the lignite is tough and dense, has a woody texture, and commonly contains carbonized and silicified plant remains. When exposed, the lignite slacks readily to a fine powder. Common mineral impurities in most of the beds are pyrite, marcasite, and gypsum. Vertical jointing is conspicuous.

Some of the lignite beds have burned, probably ignited by spontaneous combustion. At these places the overlying sandstone and claystone beds have been fused and baked to a very hard cherry-red clinker known locally as "scoria." The clinker beds resist erosion and in many localities form ledges, or cap small hills. Float derived from the clinker locally mantles the slopes. White ash, the residue of the burned lignite, underlies the clinker. Its thickness, generally less than 2 inches, depends upon the original thickness and quality of the lignite. Minor slump of the overlying strata is another result of burning. In North Dakota in the NE1/4 sec. 24, T. 159 N., R. 102 W., a 6 -foot-thick bed of lignite has burned, leaving an ash bed about 6 inches thick. Over it the clay and silt have slumped, forming a small synclinal fold. In at least one locality (pl.2), in North Dakota in the center of sec. 27, T. 159 N., R. 101 W., the burning postdates the till, for the till overlying these burned beds has been baked and fused into a hard, cohesive material. Numerous clinker fragments scattered irregularly throughout the till indicate burning of some lignite beds prior to the advance of ice across this area.

Many of the lignite beds are being mined in strip mines, inclined or vertical shafts extending as much as 100 feet below the surface, or adits in the outcrops along valley walls.

The following stratigraphic section is typical of the Fort Union formation in this area. The section probably is in the lower part of the formation, inasmuch as the underlying Cretaceous beds of the Hell Creek formation crop out about 15 miles to the west (Brown, 1949).

$460517-59 \longrightarrow 2$ 
Stratigraphio section of the lower part of the Fort Union formation along the north valley wall of the Missouri River in Montana (sec. $35, T .28$ N., R. 55 E.).

[Measured by G. B. Gott]

Shale and claystone, cream-colored to light-yellow

Shale, brown to rust-colored; some lignite

Lignite, homogeneous, dark-black, bright, platy

Shale, brown.

Shale, gray.

Sandstone, very fine grained, cream colored on weathered slopes,

2-inch-wide gray shale streaks near top.

Shale, very-dark-brown, weathered to purple and black, brittle,

thin, and platy

Covered slope, slump and vegetation.

Shale, dark-gray

Shale, gray, orange and rust-colored streaks on surface.

Ft. in. 550

10

12

3

10

Base concealed by alluvium in valley.

South of Medicine Lake, Mont., a test hole drilled by the U. S. Bureau of Reclamation in the center of sec. 6, T. 31 N., R. 56 E. reached a depth of 158 feet. The major part of the test hole is probably in the Tongue River member of the Fort Union formation.

Log of U. S. Bureau of Reclamation drill hole in sec. 6, T. $\$ 1$ N., R. 56 E., Montana

[Logged by Irving J. Witkind]

Till

Ft. in. $30 \quad 0$

Fort Union formation :

Lignite, slack, fragmentary, badly weathered.

10

Claystone, gray to light-gray, dense, locally disturbed; carbonaceous seams, plant remains, and lignite fragments scattered throughout

Lignite, dark-gray to black ; carbonaceous seam at base containing fragmentary plant remains.

:Siltstone, gray to light-brown, compact; grades into light-gray laminated claystone; a few lenses of poorly consolidated sandstone; carbonaceous and lignite seams intermixed.---

Core missing

:Siltstone, gray to light-brown, grades into fine-grained sandstone; lenses of light-gray claystone that grade into laminated shale; a few small carbonaceous seams containing plant remains

Lignite, black, dense, firm; small carbonaceous seam near top of bed.

Claystone, light- to dark-gray, laminated, locally plastic; siltstone, light-gray, that grades into fine-grained sandstone; one 10-foot-thick bed of unconsolidated light-brown sandstone; lignite seams and lime-cemented sandstone concretions intermixed 
Log of U. S. Bureau of Reclamation drill hole in sec. 6 , T. $\$ 1$ N., R. 56 E., Montana-Continued

Ft. in.

Fort Union formation-Continued

Claystone, dark-gray, laminated; grades into light-brown siltstone which in turn grades into grayish-green fine-grained

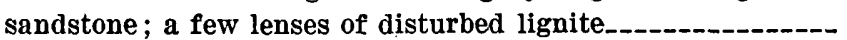

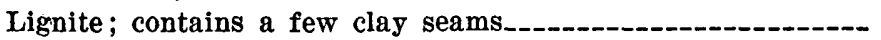

FLAXVILLE GRA VEL

The Flaxville gravel of Miocene or Pliocene age, named after Flaxville, Mont. (fig. 1), crops out between till and bedrock along the west edge of the area at an altitude of about 2,600 feet. This generally unconsolidated brownish-red predominantly quartzitic gravel ranges in thickness from 1 to about 20 feet, although farther west it is reported to be as much as 100 feet thick (Collier and Thom, 1918, p. 183). Individual beds are highly lenticular and are composed of sand lenses alternating with crossbedded gravel of smooth and well-rounded pebbles. In places lenses of sand or gravel, as much as 3 feet thick, are firmly cemented by calcium carbonate. Vertebrate fossils scattered throughout the formation have dated it as Miocene or Pliocene (Collier and Thom, 1918, p. 181).

The gravel consists of three kinds of pebbles, all siliceous (fig. 5). Most numerous is quartzite; next are varieties such as chert, flint, opal, and chalcedony, with some silicified wood. Least common are pebbles of quartz. Less resistant materials are lacking, indicating that the pebbles of the Flaxville gravel have probably been moved long distances and have undergone considerable wear prior to their deposition. Most of the gravel is rust brown on outcrops. The stain penetrates to the core of many pebbles but is only surficial on others. Pebbles derived from the Flaxville gravel can be found in stream beds in the area.

West of the Smoke Creek-Medicine Lake-Grenora area are several extensive driftless areas. In these till-free sectors the Flaxville gravel forms an undulating surface known as the Flaxville Plain (fig. 1), which probably sloped southeastward and may have extended as far as North Dakota. Remnants of this once extensive plain now appear as gravel-capped plateaus along the west edge of the Smoke CreekMedicine Lake-Grenora area.

\section{QUATERNARY DEPOSITS \\ GRAVELS OF EARLY QUATERNARY(?) AGE}

Another gravel deposit in the Medicine Lake-Smoke Creek-Grenora area, somewhat younger than the Flaxville gravel, is tentatively cor- 

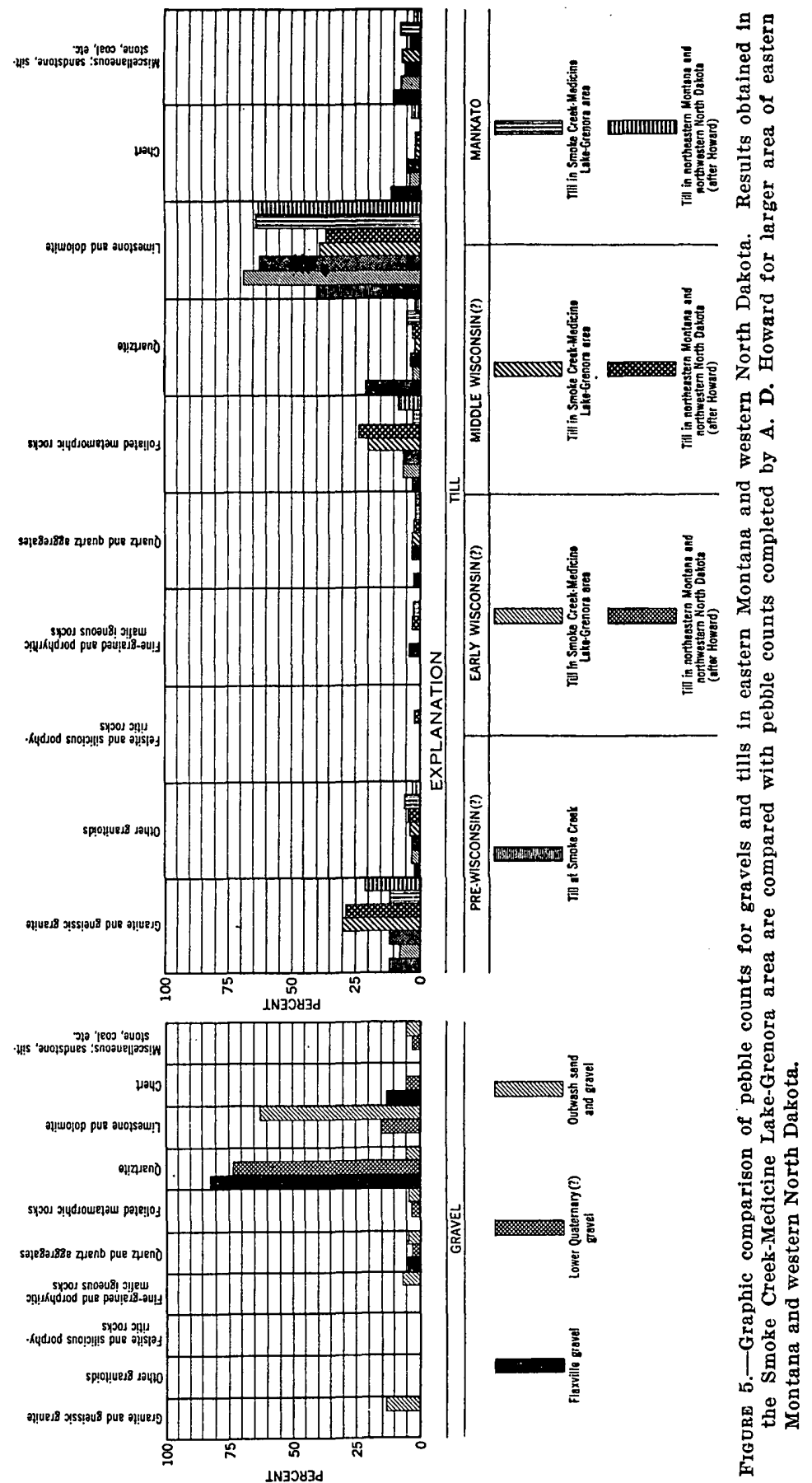
related with McConnell's South Saskatchewan gravels (1885, p. 70C). It may also correlate with the Wiota gravels farther west near Fort Peck, Mont. (Jensen, F. S., oral communication). These gravels, known as the gravels of early Quaternary (?) age, resemble the Flaxville gravel in appearance, and also crop out beneath till along many of the valley walls. They differ from the Flaxville gravel in having a slightly different composition, much smaller exposures at various altitudes, and a complete lack of fossils.

These gravels may result either from the reworking of the Flaxville gravel by glacial melt water, or they may have been formed under early periglacial conditions.

The gravels of early Quaternary(?) age consist of the same rock types as the Flaxville gravel but, in addition, include pebbles of limestone, dolomite, and foliated rocks apparently derived from the $\mathrm{Ca}$ nadian Shield (fig. 5).

Whereas the Flaxville gravel in Tps. 31 and 32 N., R. 52 E., is a continuous bed of gravel at an altitude of about 2,600 feet, the gravels of early Quaternary (?) age crop out in isolated lenses that are at various lower altitudes. Where they crop out along the valley walls of Smoke Creek and Big Muddy Creek their lateral extension ranges from 200 feet to a maximum of 2 miles.

An outcrop of gravel 1 mile southeast of Coalridge, Mont., can presumably be correlated with the gravels of early Quaternary(?) age and represents the easternmost exposure. The gravel is exposed between till and bedrock in a pit in the middle of sec. 19, T. 34 N., R. 58 E. Three outcrops of gravel near Coalridge were sampled. The close similarity between these gravels and other gravels of early Quaternary(?) age suggests that they are equivalent. The principal foreign pebbles consist of limestone and dolomite.

As yet, no fossils have been found in the gravels of early Quaternary (?) age in this area. This contrasts markedly with the relative abundance of vertebrate remains in the Flaxville gravel.

Similar gravels are exposed in southwestern Alberta. In at least one locality they pinch out against a bedrock surface, much as one would expect along the banks of a stream (Dawson and McConnell, 1895, p. 43). Although no similar exposures have been found in the Medicine Lake area, the limited extent of the gravels and the variation in their altitudes suggest that they represent buried former stream courses. exposed by the present drainage. In places the intersection is normal to the buried course, so the outcrop is narrow, as in those gravels along Smoke Creek. Elsewhere the present drainage parallels the buried course and the gravel exposures are longer, as along the west wall of Big Muddy Creek valley. 
The age of the gravels of early Quaternary(?) age in this area is in doubt because of the uncertainty of their origin. They may be late Tertiary and may have resulted from reworking of the Flaxville gravel, but the limestone and dolomite pebbles suggest that foreign pebbles have been added. These could have been supplied by outwash or from local till of an early Pleistocene glacier.

\section{PLEISTOCENE DEPOSITS}

The area is mantled by till (nonstratified drift) and glaciofluvial deposits (stratified drift), with the former predominating. Commonly, contacts between the two are indefinite. Several till sheets of different ages can be distinguished, principally by their topographic expression, but in part by slight differences in the types and amounts of included pebbles. Two types of glaciofluvial deposits are present: (a) Channel outwash (proglacial) deposits, which consist of sand and gravel, derived from a melting ice sheet and deposited by melt water in all of the major valleys and in most of the smaller ones, and (b) ice-contact deposits such as kames and eskers which are scattered across the till surface.

\section{TILI SHEETS}

Several till sheets mantle the area, but the differences between them are not marked. The till is similar in general appearance and mode of outcrop; it is only on close examination that variations are apparent. In some localities the till sheets differ both in topographic expression and in composition; elsewhere, their surfaces are alike but their composition distinguishes them.

Although Howard (see page 4) has distinguished tills of three ages nearby, the distinction cannot be made consistently in this area. By extrapolation of his work it is probable that till of three agesMankato, middle Wisconsin(?), and early Wisconsin(?) - are represented (pl. 1). Possibly a till-like deposit at Smoke Creek represents a fourth (p. 18). The till of Mankato age is characterized by a welldeveloped knob and kettle topography. The till of middle Wiscon$\sin ($ ?) age has a surface relatively free of kettles and is marked by well-integrated drainage lines. It contains moderate amounts of limestone and dolomite pebbles. The till of early Wisconsin(?) age is also characterized by a well-integrated drainage system, but it differs in composition from the middle Wisconsin (?) till in having much greater amounts of limestone and dolomite pebbles and lesser amounts of crystalline rocks. Within the area investigated by Howard, the early Wisconsin(?) till is the only one of the three drifts which crosses the Missouri River.

\section{PHYSICAL PBOPERTIES}

The till sheets consist of unsorted sand, gravel, and boulders bound together by clay to form a tough, compact material. The till is blue 
gray where unoxidized and light or dark brown where oxidized. All the till is moderately calcareous, and in most places the upper 16 inches or so has been leached and the lime redeposited in a zone about 1 foot thick beneath the leached layer. This zone conforms to the topography. The clay, by far the most abundant constituent, was probably derived by ice scour from the underlying Fort Union formation, whereas the coarser material is foreign to the area. These erratics, of all sizes, are embedded in the till and veneer its surface. Most of the boulders have been derived from the Canadian Shield. Well-rounded fragments of buff-colored limestone and dolomite are the most common, although pink granite, pegmatite, gneiss, and schist are plentiful. Many pebbles derived from the Flaxville gravel or other old gravel deposits are also embedded in the till.

In an attempt to differentiate the drifts, a system of pebble counts introduced by Howard was used. In this method, an area of about 2 square yards was cleared on a vertical or near vertical face and all slope wash was removed. All pebbles less than one-half inch in diameter were discarded; generally, about 200 pebbles were collected. In till, each pebble was dug out of the fine-grained matrix. In gravel, a sample was collected and then quartered. A chip was collected from each cobble or boulder. Each pebble was then broken, examined, and classified.

The classification used, also after Howard, includes 10 major rock groups:

Granite and gneissic granite.

Other igneous rocks having a granitic texture.

Felsite and silicious porphyritic rocks.

Fine-grained and porphyritic mafic igneous rocks.

Quartz and quartz aggregates.

Foliated metamorphic rocks.

Quartzite—quartzite pebbles, most of which are derived from the Flaxville gravel.

Limestone and dolomite, mostly buff-colored with slight manganese staining.

Chert and other cryptocrystalline silica rocks; most are characteristic of the Flaxville gravel.

Miscellaneous pebbles of sandstone, siltstone, shale, claystone, coal, limonite, petrified wood, clinker, and other sedimentary rocks.

A percentage of each grouping was then computed and the results plotted. The resulting graphs presumably represent an average of the rock material embedded in the till or contained in the gravel.

A comparison between the averages as determined by Howard for the three till sheets in the Williston area (fig. 2) and those resulting from 30 similar pebble counts in this area is shown in figure 5.

Lithologically, the Mankato and early Wisconsin(?) drifts in this area are very much alike. Both contain considerable limestone and dolomite, granite, foliated metamorphic rocks, and fine-grained mafic rocks. The middle Wisconsin(?) drift differs in composition from 
these two by its smaller amounts of limestone and dolomite and a corresponding preponderance of crystalline rocks.

Efforts to distinguish between drifts by variation in the thickness of the caliche on pebbles were disappointing (Howard, 1947a, p. 1194). Greater variations were found within the same drift than in presumably different drifts.

No fossil soils were found here, but Howard (1947b, p. 1195) reports a thin fossil soil separating the intermediate and oldest till sheets.

The till varies in thickness from a thin film to more than 75 feet. Excavation is needed to determine whether a particular hill consists of till or of till-mantled bedrock. A drill hole on the north side of Medicine Lake penetrated 75 feet of till overlying fluvial sand and gravel.

\section{TOPOGRAPHIC EXPRESSION}

The east and west halves of the area differ topographically. West and south of Medicine Lake the ground surface is undulatory and comparatively smooth, with few kettles; the drainage is largely integrated. East and north of Medicine Lake, however, the topography is totally different. Features suggesting recent deposition by ice abound; a knob and kettle topography predominates, and integrated drainage is rare. This distinctly morainal area extends from the east edge of Medicine Lake northeastward across the late Wisconsin Max moraine (p. 6, 8). However, beds of the Fort Union, as well as a layer of gravel like the Flaxville gravel, crop out near the crest of the Max moraine, indicating that the height of the moraine is locally due to bedrock rather than an accumulation of glacial debris (Howard, Gott, and Lindvall, 1946, p. 1204).

TILL(?) ALONG SMOKE CREEK

A small outcrop of probable till along the east bank of Smoke Creek (fig. 1) in sec. 20, T. 30 N., R. 54 E., overlies a layer of lightyellow silt and a bed of gravel of early Quaternary (?) age and underlies the early Wisconsin(?) till (fig. 6). This till(?), unlike the younger ones, is light tan, massive, very hard, and contains few pebbles. The pebbles are igneous and metamorphic rocks, with limestone and dolomite pebbles predominating. Most are small, well rounded, and stained with manganese. The manganese stain also lines fractures in the matrix. A comparison between the lithologic composition of the buried till and the early Wisconsin(?) till is shown in figure 5. In general the two are alike despite their totally different appearance at the outcrop. The exposure along Smoke Creek is the only known outcrop of this till(?) in the area. 


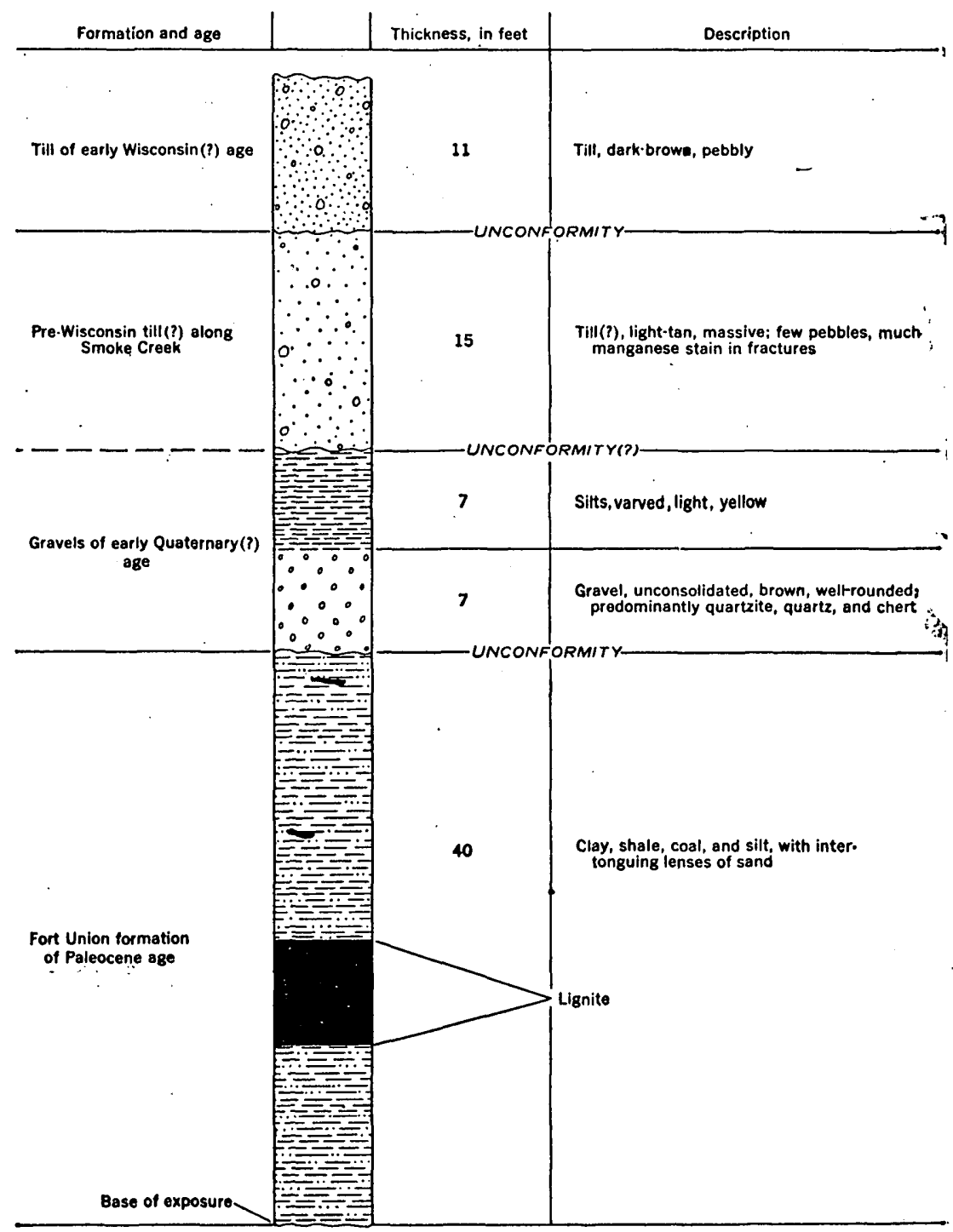

Figure 6.-Stratigraphic section showing tills along east valley wall of Smoke Creek in Montana (sec. 20, T. 30 N., R. 54 E.)

\section{GLACIOFLUVIAL DEPOSITS}

Two types of glaciofluvial deposits are found in the Smoke CreekMedicine Lake-Grenora area. The first are channel outwash (proglacial) deposits and consist of sand and gravel deposited by glacial melt water beyond or in advance of the glaciers. The second type comprises ice-contact deposits, such as kames and eskers, which have been formed under or against the ice. 
CHANNEL OUTWASH DEPOSITS

Distribution and general relations.-In general the melt-water channels in the Smoke Creek-Medicine Lake-Grenora area have two different forms (fig. 7). Some of the channels are veneered and floored with till. These form narrow, elongate, sinuous till-covered sags that reflect the former courses of the channels. Locally the till is thick enough to fill the channels and conceal them. As a result these channels cannot be traced with assurance on the surface, but they can be detected by geophysical methods. Others of the channels have till on their flanks but their floors are composed of outwash. These are the typical outwash channels and they can be traced for many miles. It is these channels that have been named and are here described.

The till-covered outwash-free channels represent valleys that existed prior to their burial by ice. Some may have formed preglacially. Others may have formed as ice-marginal channels during halts of an advancing ice sheet that were subsequently overridden by a renewed ice advance and veneered or buried by till.

Those channels floored with outwash sand and gravel may have been formed in one of several ways. Some of the valleys blocked by ice may have been reoccupied by melt water as the ice melted. Others of the channels may represent new ice-marginal channels cut during halts in the withdrawal of the ice.

All the extensive deposits of sand and gravel that fill the broad valleys traversing this area are channel outwash deposits (fig. 8). The outwash forms an uninterrupted sheet that can be traced from one channel fill to the next. Most of the outwash-filled channels are commonly graded toward the south, and the margins are higher than the centers. Kettles and kettle lakes are numerous in channel fill in the east half of the area, but are sparse in the west half.

In a few localities the outwash forms relatively flat-topped ridges topographically higher than the adjacent till surface. This inversion of topography probably resulted from the confinement of sedimentloaded streams between wasting ice blocks. With the disappearance of the ice, the accumulated sand and gravel remained essentially undisturbed as a broad ridge of outwash. The extreme width, usually $1 / 2$ to 1 mile, clearly distinguishes these features from true ice-contact deposits such as eskers, kames, or crevasse fillings.

Bedding and composition.-The bedding of the outwash is most variable and seems to change at random, grading laterally from even bedded to crossbedded. The grain size ranges widely and increases towards the head of the deposit. Locally, however, the deposit is fairly uniform in texture, with pebbles and cobbles scattered throughout. Some unusually large boulders probably have been icerafted to their present positions. Most pebbles range from subangular to poorly rounded. 


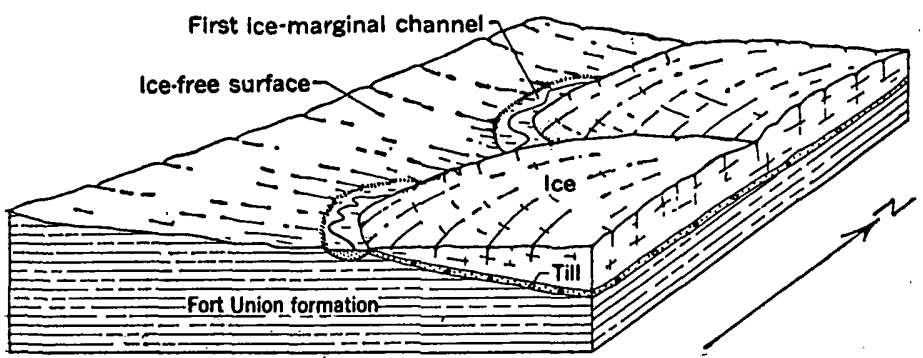

A.
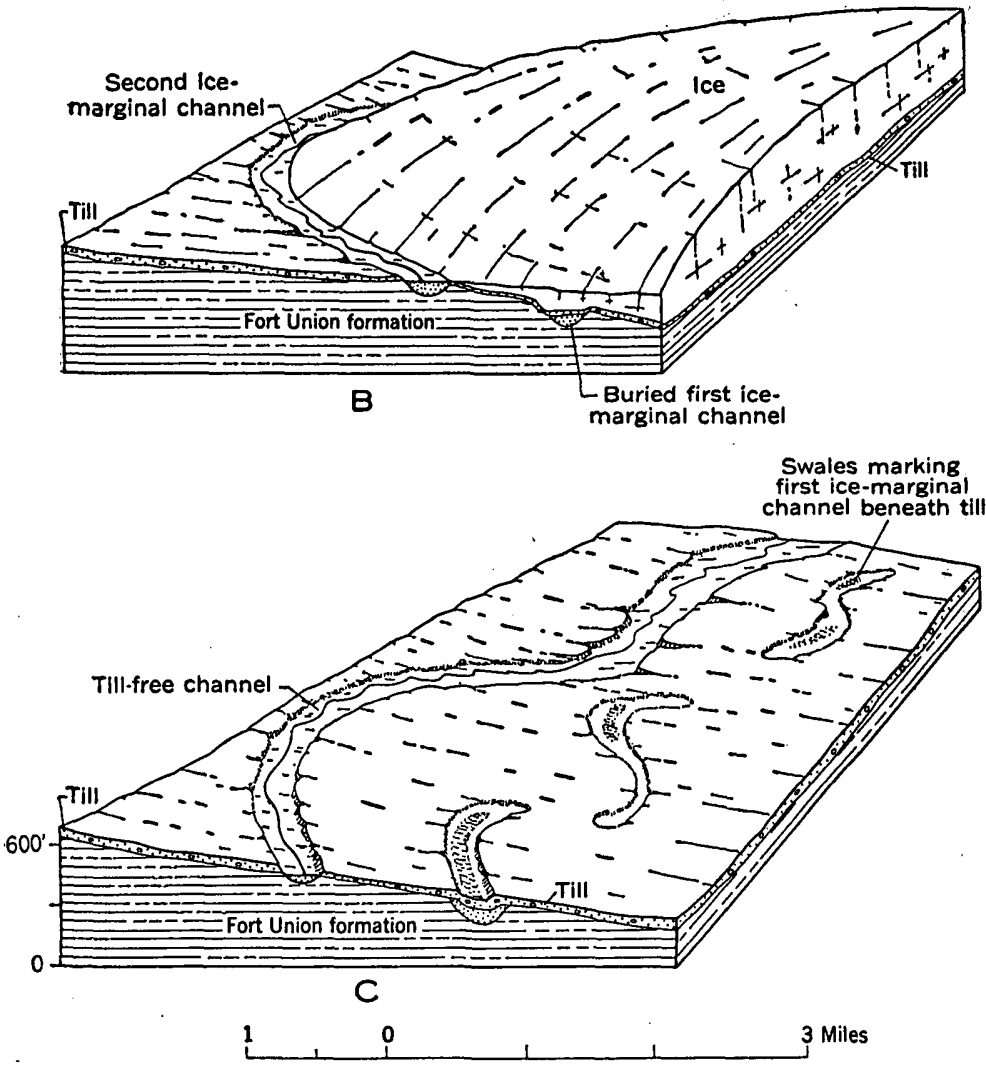

Figdre 7.-Three stages in the development of thll-surfaced valleys in the Smoke Creek-Medicine Lake-Grenora area. $A$, During a halt in the westward advance of a continental ice sheet, melt water cut a marginal channel across the regional surface, which sloped eastward. $B$, A readvance of the ice buried the first marginal channel, and a second marginal channel was formed west of the first during a halt in the withdrawal of the ice. $\sigma$, with the subsequent melting of the ice, a till-covered surface was exposed. The first marginal channel, which was overridden by the ice, is reflected now by elongate undrained depressions that are commonly occupied by small saline lakes. The second marginal channel, which was not buried by the ice, is till free and shows as a broad sand and gravel tract occupied by a small intermittent stream. 


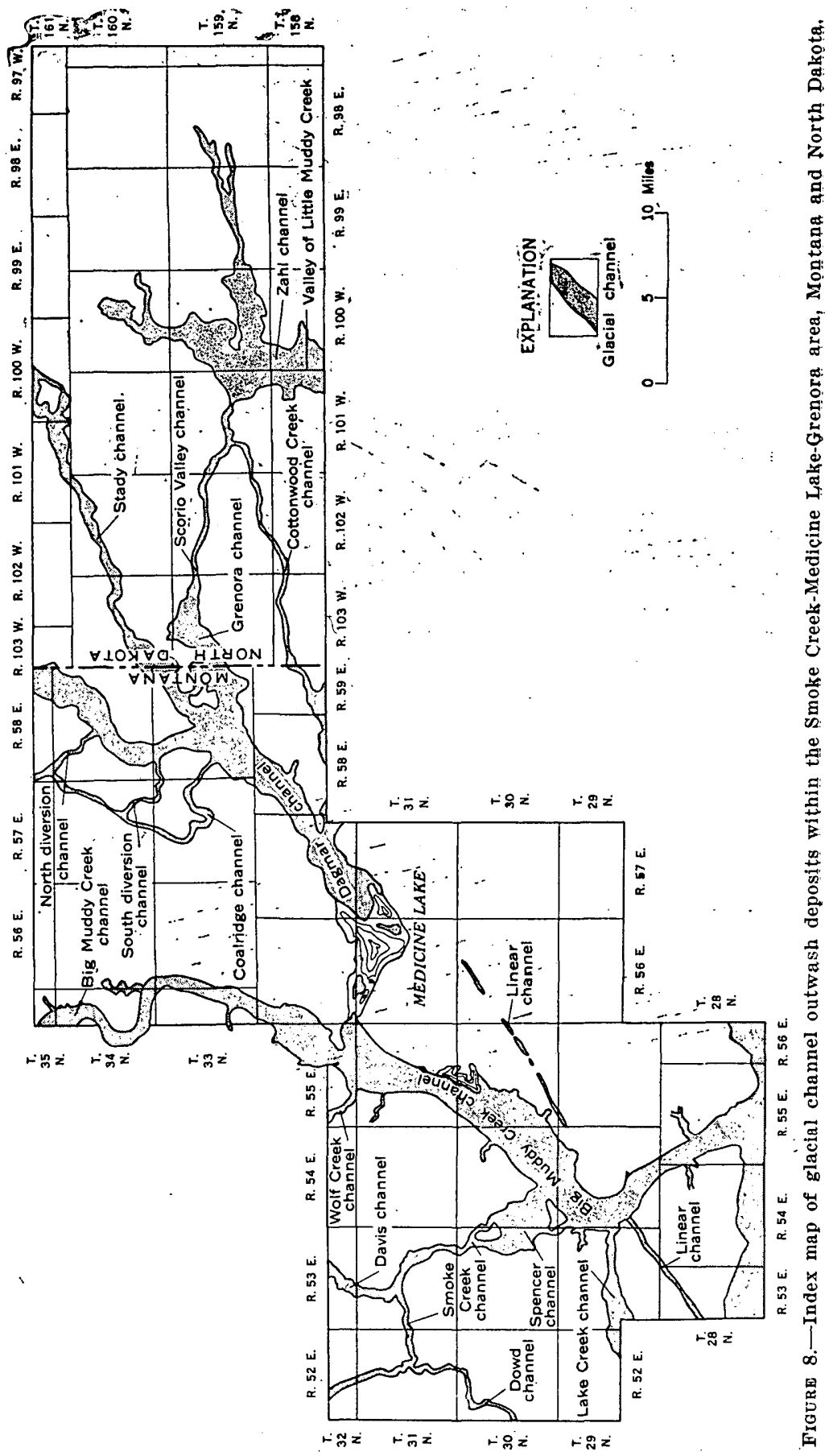


The composition of the outwash is similar to that of the Mankato till : the four dominant rock types are limestone and dolomite, schist, mafic fine-grained rocks, and granite (fig. 5). The preponderance of the limestone and dolomite clearly distinguishes the outwash from either the Flaxville or gravels of early Quaternary(?) age. The lithologic similarity of this outwash and the Mankato till suggests that both were deposited from the same ice sheet. This is also suggested by the continuity of the sand and gravel fill within the main channels and their tributaries. Thus, uninterrupted outwash deposits can be traced northward up Big Muddy Creek to the Dagmar channel and thence northeastward to the foot of the northwestward-trending ridge capped by the Max moraine.

The thickness of the outwash varies considerably within the same channel and from one channel to another. In Scorio Valley, for example (fig. 9), drilling reveals that the outwash thins at a point about $11 / 2$ miles east of Grenora in sec. 8, T. 159 N., R. 102 W., and then increases again to the west, beyond this point. No indication of this is apparent at the surface of the outwash, which slopes westward. The outwash in Scorio Valley ranges from 40 to at least 70 feet in thick"ness, yet drill holes and exposures in similar fill in the nearby Stady channel (fig. 8) suggest that this fill probably does not exceed 25 feet. - Former valleys buried beneath till most likely resulted in surface depressions which influenced the direction in which the melt water flowed. This may explain, in part, the variation in depth of fill within one channel. Elsewhere, the melt water, at least in some stages, seems to have been capable of eroding channels in bedrock.

In 1948, geophysicists of the U. S. Geological Survey completed a resistivity investigation near Medicine Lake in order to reveal any channels in bedrock that might be buried by gravel or till. The fieldwork was carried out by G. J. Edwards (1951). I have superposed the geophysical data upon a geologic map of the area (pl. 3), and in the discussion of the major channels the geophysical interpretations have been integrated with the geological data.

Five resistivity profiles were completed across the major channels in the area. One profile (B) crosses the Big Muddy Creek valley. The other profiles (A, C, D, E) cross parts of the Dagmar, Stady, and Grenora channels. Profile A parallels a line of test holes (fig. 13) and in general agrees with the drilling results, although locally it indicates a lesser depth to bedrock.

\section{ICE-CONTACT DEPOSITS}

Distribution and general relations.-Kame terraces, kames, eskers, and crevasse fillings are widely distributed in the east half of the area but are sparse in the west half. All rest on till and most show little evidence of dissection, although those in the west half commonly have 


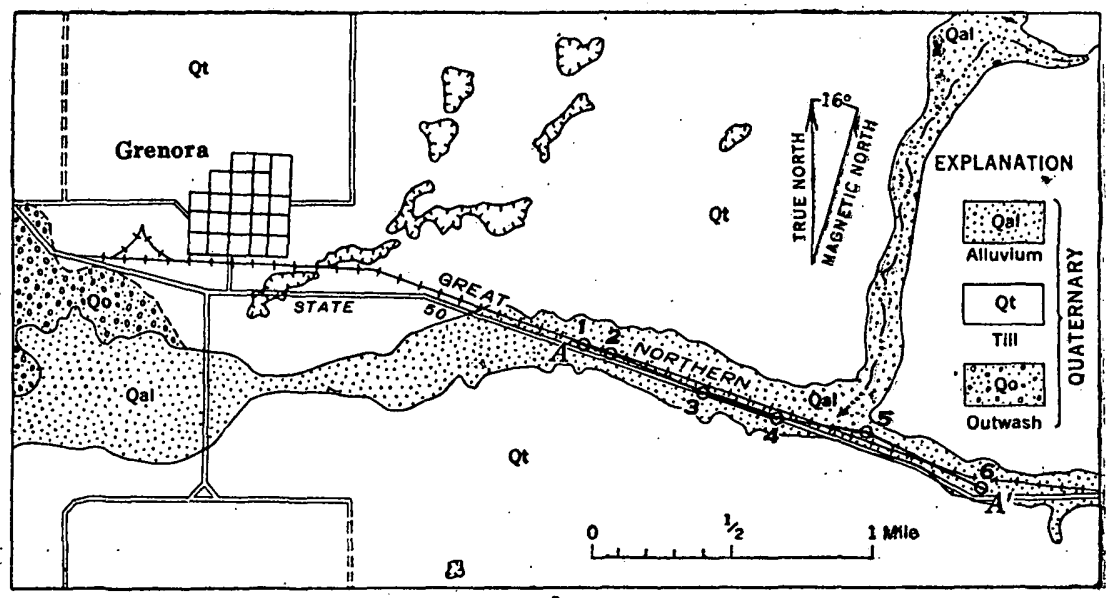

A

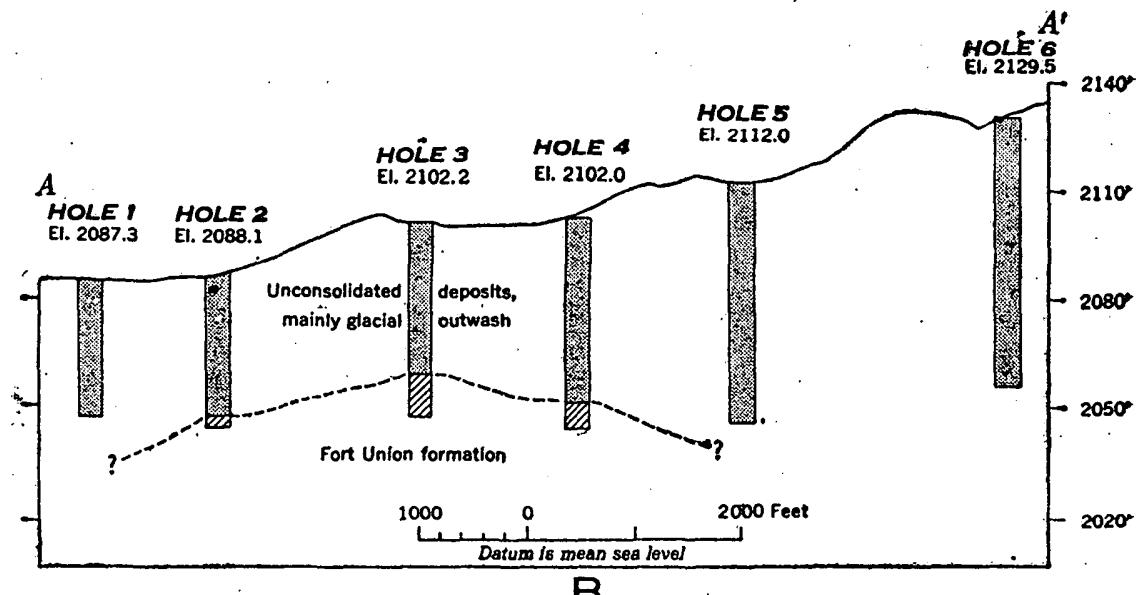

Frourb 9.-Drill holes and their logs in the Scorio Valley channel. A, Location of drill holes in the flood plain of Scorio Valley east of Grenora. $B$, Graphic representation of the logs of drill holes along the length of Scorio Valley. Note the thinning of the outwash due to a bedrock prominence at hole 3 . No surface indication is given of this bedrock high. Drill logs furnished by Bureau of Reclamation show only depth to top of Fort Union formation.

breached kettles and are slightly more dissected than those in the east half. Locally those in the west half are totally or partly concealed beneath till. This suggests that a few were overridden by readvancing ice after they were formed. 'Those ice-contact deposits in the east half are till free.

Although these deposits can be distinguished topographically, they have other characteristics in common. All are composed of poorly sorted sediments that even include blocks of till; wedge-shaped blocks 
of till and boulders commonly mantle their surfaces. Their surfaces are pitted with kettles as much as 10 feet in diameter and 3 feet in depth. Most of the eskers and crevasse fillings are oriented toward the southwest.

In a few places the features form clusters, as in the southwest corner of T. 28 N., R. 55 E., north of Medicine Lake (fig. 1), where kames occur in a group. A similar group is found farther west in Tps. 29 and 30 N., R. 53 E. Eskers are common in the general area near Grenora, N. Dak. (fig. 1).

Bedding and composition.-In the kames, eskers, and crevasse fillings, the bedding is erratic and dips steeply. In the kame terraces the deposits are even bedded, but locally they give way to bedded sediments that dip as steeply as $60^{\circ}$.

Most of the sediments forming these deposits consist of angular to poorly rounded pebbles of limestone and dolomite and crystalline rocks. The rock types in these deposits are similar to those in the underlying till. Pebbles of quartzite, quartz, and chert like those in the Flaxville gravel are plentiful. Some of the more extensive kame terraces and eskers show a crude sorting, becoming coarser to the northeast. Commonly, however, the material changes rapidly in texture and the sorting is poor. In places the range is from fine-grained sand to huge glacial boulders.

\section{AGE RELATIONB}

TH.C BHEETS

Extrapolating from the Williston, N. Dak., area where Howard (see page 4) has differentiated 3 drifts, it seems likely that till of 3 ages also mantles the Smoke Creek-Medicine Lake-Grenora area (p. 16). Of these, the youngest is referred to the Mankato substage of the Wisconsin and is distinguished by its knob and kettle topography and its lack of an integrated drainage system. This till covers most of the area east and north of Medicine Lake and can be traced northeastward across the Max moraine (fig. 1). Elsewhere in the area the surface expression of the till sheets is alike-drained kettles and a well-integrated dendritic drainage system. However, a comparison of the pebble counts has suggested that two till sheets are present beyond the limits of the Mankato till. The possible areal extent of these is shown in plate 1. Evidence that would permit a specific age assignment for either of these two drifts was not found in this area. Howard has tentatively assigned a middle Wisconsin (?) age to glacial drift widely exposed near Williston. In the Smoke Creek-Medicine Lake-Grenora area, this till is exposed only south of Zahl, N. Dak. The greatest part of the area is covered by till that has been dissected into a rolling upland. Only a few kettles are left, and of these some 
are breached and the remainder are nearly filled with silt and sand. The drainage system is well established and extends far back into the uplands. Alden $(1932$, p. 87) has referred this till to the Iowan or Illinoian. As I have found no evidence contrary to this, $\mathrm{I}$ assign it tentatively to the early Wisconsin(?). The age of the till(?) along Smoke Creek is unknown.

The area that the Mankato ice covered can be estimated by the presence or absence of knob and kettle topography. The terminal limits of the ice are marked by outwash channels rather than accumulations of drift. The Coalridge channel (pl. 4) probably marks the northwest limit of the ice (p. 40), and the Cottonwood Creek channel (pl. 4) probably marks the southern limit of the Mankato ice (p. 43). The till upland beyond the postulated ice limit is marked by an extensive dendritic drainage pattern in broad well-developed valleys. Within the area that was covered by ice, the valleys are short and relatively straight, and a knob and kettle topography is common.

\section{CHANNEL OUTWASH DEPOSITS}

It is unknown when most of the outwash channels developed, although the sand and gravel filling them is probably of Mankato age. This is suggested by the lithologic similarity of the outwash and Mankato till and by the uninterrupted sheet of outwash that can be traced from one channel to another.

No outwash was found that could be ascribed unequivocally to melt water of the early or middle. Wisconsin(?) ice sheets. Along the valley walls of Big Muddy Creek near Antelope, Mont. (fig. 1), extensive deposits of sand and gravel are exposed below a thick layer of early Wisconsin(?) till (p. 28). These may represent outwash deposited in pre-Wisconsin time or possibly formed by melt water from the advancing early Wisconsin(?) ice. It does seem likely, however, that outwash was deposited by melt water from both the early and middle Wisconsin ice sheets and that it is now concealed beneath younger Mankato outwash or till.

\section{ICE-CONTACT DEPOSITS}

On the basis of the postulated extent of the Mankato ice in this area, two ages of ice-contact deposits are present in the Smoke Creek-Medicine Lake-Grenora area. All the ice-contact deposits in the crude triangular area delineated by the Coalridge channel on the northwest and the Cottonwood Creek channel on the southeast (pl. 1) are Mankato in age. Those west of the Coalridge channel and south of the Cottonwood Creek channel are assumed to be early Wisconsin (?) in age. Ice-contact deposits of middle Wisconsin(?) age have not been found. 
The strata exposed along the east bank of Smoke Creek in sec. 20, T. 30 N., R. 54 E. (fig. 6), suggest at least one pre-Wisconsin glacial advance into the Smoke Creek-Medicine Lake-Grenora area. In this exposure the Fort Union formation is overlain by about 7 feet of brown unconsolidated well-rounded gravel that consists predominantly of quartzite, quartz, and chert, but which also contains exotic materials derived from the Canadian Shield. This gravel is tentatively assigned to the gravels of early Quaternary(?) age. About 7 feet of light-yellow varved silt overlies the gravel, with a sharp contact between. The silt, in turn, is overlain by a light-tan massive well-indurated material which may be till. The contact between the till(?) and the silt is marked by small irregularities. Overlying this till (?) is the dark-brown early Wisconsin (?) till which mantles this part of the Smoke Creek-Medicine Lake-Grenora area. The contact bet ween the two till sheets is marked by small scours.

One possible hypothesis to explain this sequence of strata is that an early Pleistocene ice sheet blocked a stream flowing on Fort Union strata and formed a lake. In this lake varved silt was deposited. With the continued advance of the ice the lake was destroyed and a till-like material was deposited, burying the silt. On withdrawal of the ice the till(?) was exposed to erosion. Judging by the indurated character of the till this ice-free period was long. This till was subsequently buried by the ice that deposited the early Wisconsin(?) till.

\section{EARLY WISCONSIN(?) CHANNELS}

A series of channels filled with outwash sand and gravel dissect the Smoke Creek-Medicine Lake-Grenora area. Although it is unknown when these channels were cut (p. 26), those beyond the limits of the Mankato ice must have been formed in pre-Mankato time. As till of early Wisconsin (?) age covers the western part of the area, the channels in that part are considered to have been cut principally by melt water of the early Wisconsin(?) ice. The floors of these early Wisconsin(?) channels are formed of sand and gravel that is much younger and is probably Mankato in age.

BIG MUDDY CREEK CHANNEL

The Big Muddy Creek channel, clearly delineated along its length from the international boundary to its accordant junction with the valley of the Missouri River, is one of the most striking physiographic features of the area (fig. 8). It follows an erratic course across Sheridin and Roosevelt Counties, Mont., as a wide outwash-filled valley. Along most of its length an ice-marginal mode of formation is implied: in places it conforms to the regional slope of the land, elsewhere it is at some angle to this slope. The channel ranges in $460517-59-3$ 
width from about 1 mile to a maximum of 3 miles near Medicine Lake.

All tributary channels, including the Wagmar, Wolf Creek, and Smoke Creek channels (pl. 1), enter accordantly. The accordant junction of the Dagmar channel is significant because the fill in the Dagmar channel is almost certainly of Mankato age. The Big Muddy Creek channel fill contains a preponderance of limestone and dolomite types, as does the Dagmar channel fill. The accordant junctions of these two channels and the lithologic similarity of their fills suggest that the outwash in the Big Muddy Creek channel is also of Mankato age.

Big Muddy Creek, a sluggish perennial stream, drains the channel. Its width, a mere 10 feet in most places, is incongruous when compared to the wide channel. This incongruity is emphasized when it is considered for how brief a period of time the stream has occupied the valley. A meander belt about one-quarter mile wide wanders in wide curves from valley wall to valley wall. The outwash is mantled by alluvium, which may be as much as 100 feet thick near its south end (p. 34). Some of the tributary channels have been similarly alluviated, although not so deeply.

Much of the history of the channel and of the entire area can be determined from the exposures along a small part of the valley just west of the town of Antelope, Mont., in sec. 24, T. 34 N., R. 55 E. (fig. 10). The channel forms a horseshoe-shaped bend to the west, although north and south of this bend its course is relatively straight. The channel is slightly narrower within the bend, as first noted by Bauer (1912, p. 295). Moreover, the bend in the channel is incised into an eastward-sloping till surface which descends to a shallow longitudinal northward-trending sag, in which the town of Antelope is located. The land surface rises east of the Antelope sag.

Fort Union strata are exposed along the bend but are missing at both the north and south ends (pl. 1). In these localities the till that forms the uplands rests principally on broad deposits of sand and gravel. Where Antelope Creek cuts across the south end of Antelope sag in sec. 25, T. 34 N., R. $55 \mathrm{E}$., only till is exposed along the valley walls.

North of the bend in sec. 14, T. 34 N., R. 55 E., and south of the bend in sec. 36, T. 34 N., R. 55 E., broad flat-surfaced deposits of sand and gravel are exposed along the valley walls. In the small reentrants that dissect these deposits the sand and gravel can be traced below a thick till cover. Other similar deposits of sand and gravel are exposed along the bend. These, however, rest on and abut Fort Union strata and in no place was till found resting on them. Both the tillcovered and till-free deposits were mapped as terrace deposits by Alden (1932, p. 61). 


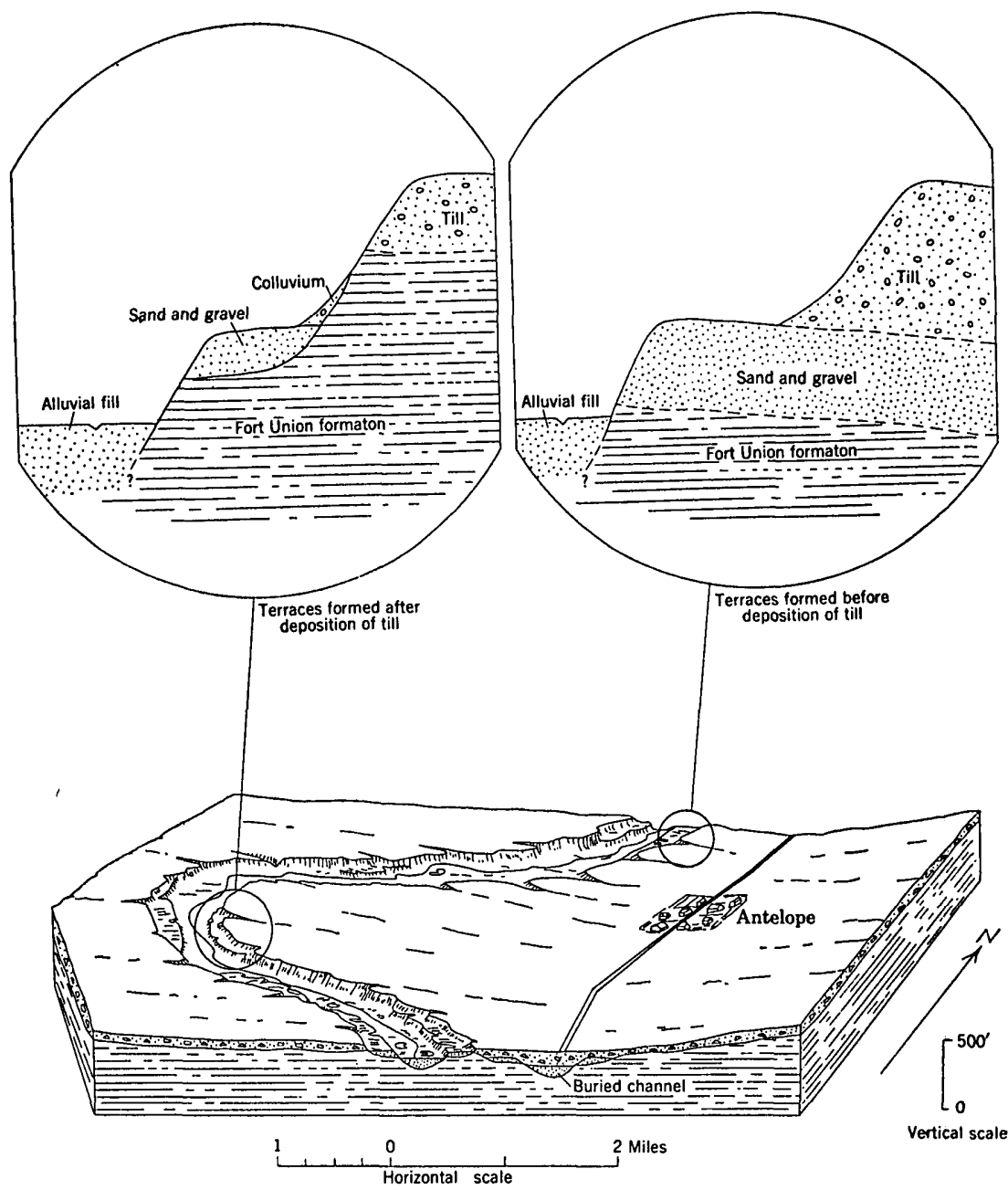

Figurn 10.-Block diagram llustrating the ages of two terrace deposits in the Big Muddy Creek valley near Antelope, Mont. The terrace west of Antelope is postglacial, the terraces north of Antelope were formed before the deposition of the till.

The till-covered and the till-free sand and gravel deposits are remarkably accordant in their height- 40 feet-above the flood plain. Further, a lithologic comparison of the gravels of the two deposits shows considerable similarity. Both contain high percentages of quartzite as well as limestone and dolomite (fig. 5).

The incision into an eastward-sloping land surface, the northwardtrending Antelope sag, the narrowing of the channel around the bend, the absence of Fort Union strata at the north and south ends of the bend, and the presence of what may be two ages of terrace deposits, suggest the diversion of a preexisting stream. If so, the stream's original course is now marked by the Antelope sag. How- 
ever, little direct evidence is available as to the form of the till-buried channel or the thickness of the fill. One water well in Antelope has been drilled to a depth of 110 feet, but no well log is available; other wells there have penetrated about 50 feet of glacial drift before reaching water.

My interpretation of the geomorphic history of the Antelope area is given in figure 11. There is no evidence to indicate whether the buried channel was formed in an earlier glacial stage than the present channel or in the same one. The older age is considered the more likely as the water required to cut such a channel would in general be released during the wasting rather than the expansion of an ice sheet.

It seems likely that when the ice buried the ancestral channel; the water was ponded and diverted into marginal escape channels. The diverted water flowed in the new course until entrenched in the eastward-sloping land surface. The presence of at least one terrace surface within the bend suggests that the entrenchment took place in at least two stages. The diverted water cut a new channel not only around the horseshoe-shaped bend at Antelope but also as far south as Medicine Lake. Below Medicine Lake, however, the greater width of the channel suggests that the course of the new channel coincides more or less with that of the old channel.

How deeply these diverted streams cut is unknown, nor is it known how much of the fill in the Big Muddy Creek valley was deposited at this time. Much of the fill, however, is probably of Mankato age, as explained on page 26 .

The exact course of the ancestral Big Muddy channel through this area is unknown. Its probable direction is shown in figure 12. The course of the buried valley was plotted for part of its length by bedrock outcrops or surface indications of meander scars buried beneath till, which are found at various localities along the present Big Muddy Creek valley. A prominent meander scar northeast of Reserve, Mont., appears as a trough in the till-buried topography in secs. 17, 20, 30, 31, and 36, T. 33 N., R. 56 E.

Along the path delineated for the ancestral channel, sand and gravel deposits are exposed below till, either in stream valleys or along road cuts. Whether these deposits are related to the till-covered sand and gravel deposits near Antelope is unknown, although this is suspected. An excellent section through a till-buried sand and gravel deposit, which slopes southward, is exposed in a road cut along Montana State Highway 16 in sec. 7, T. 33 N., R. 56 E. This sand and gravel can be traced northward to a point where the deposit abuts bedrock, similarly buried beneath till. Another sand and gravel deposit beneath till is exposed along the north valley wall of Otter Creek in the NW1/4 sec. 26 , T. 33 N., R. 55 E. 

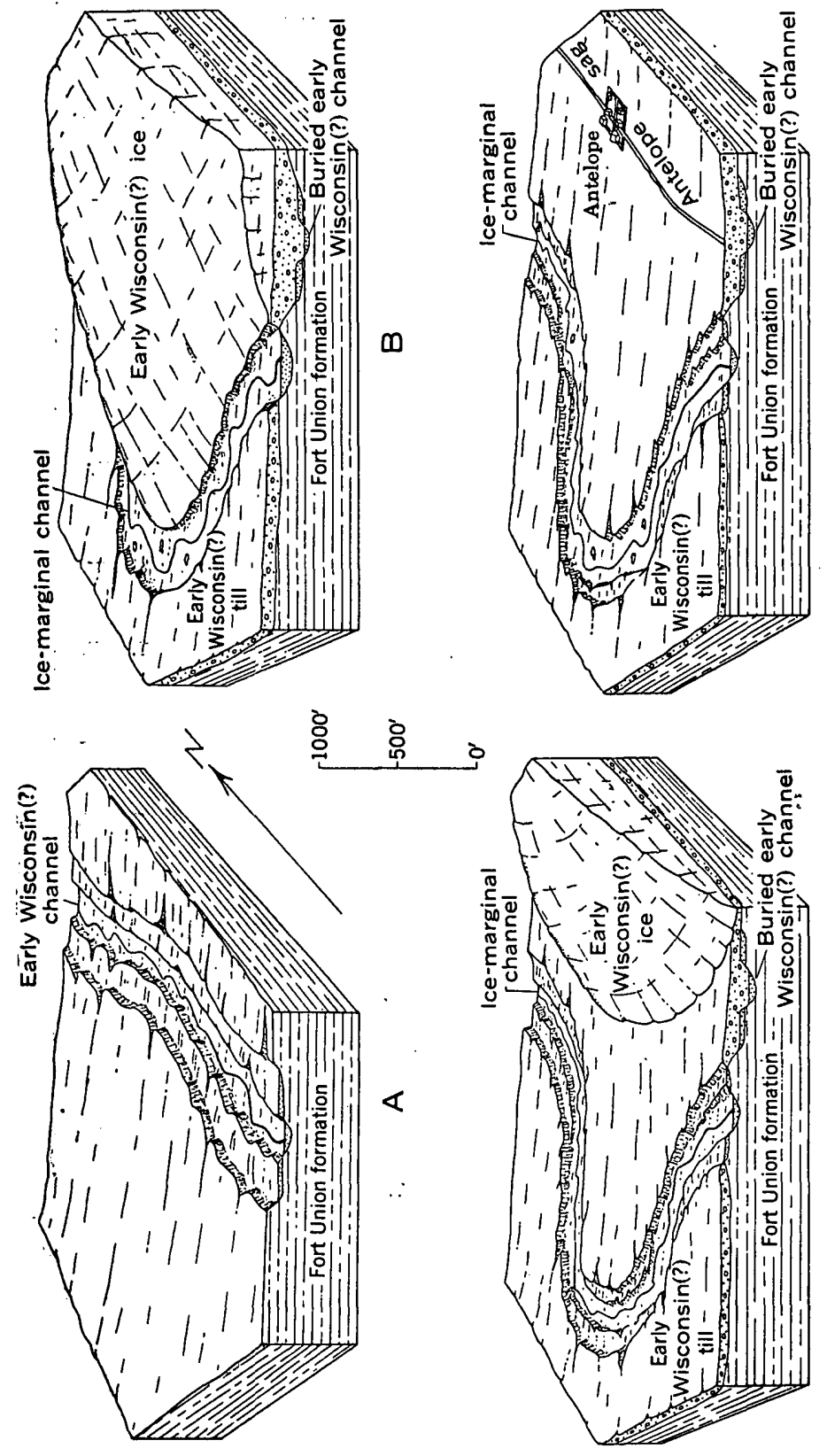

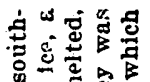

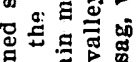

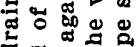

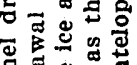

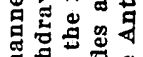

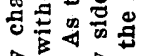

然邑罚

口

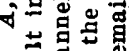

๘

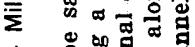

○] 응

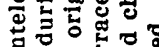

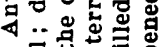

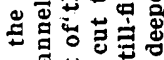

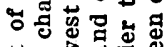

苛品 击

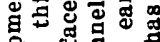

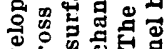

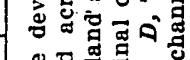

¿

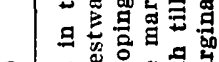

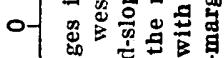

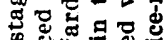

$\checkmark$ 台总总要 -

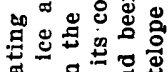

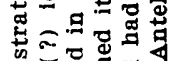

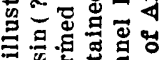

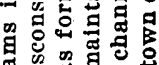

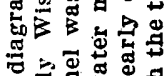

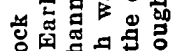

ติ डั

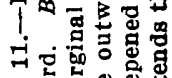

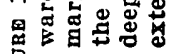

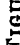




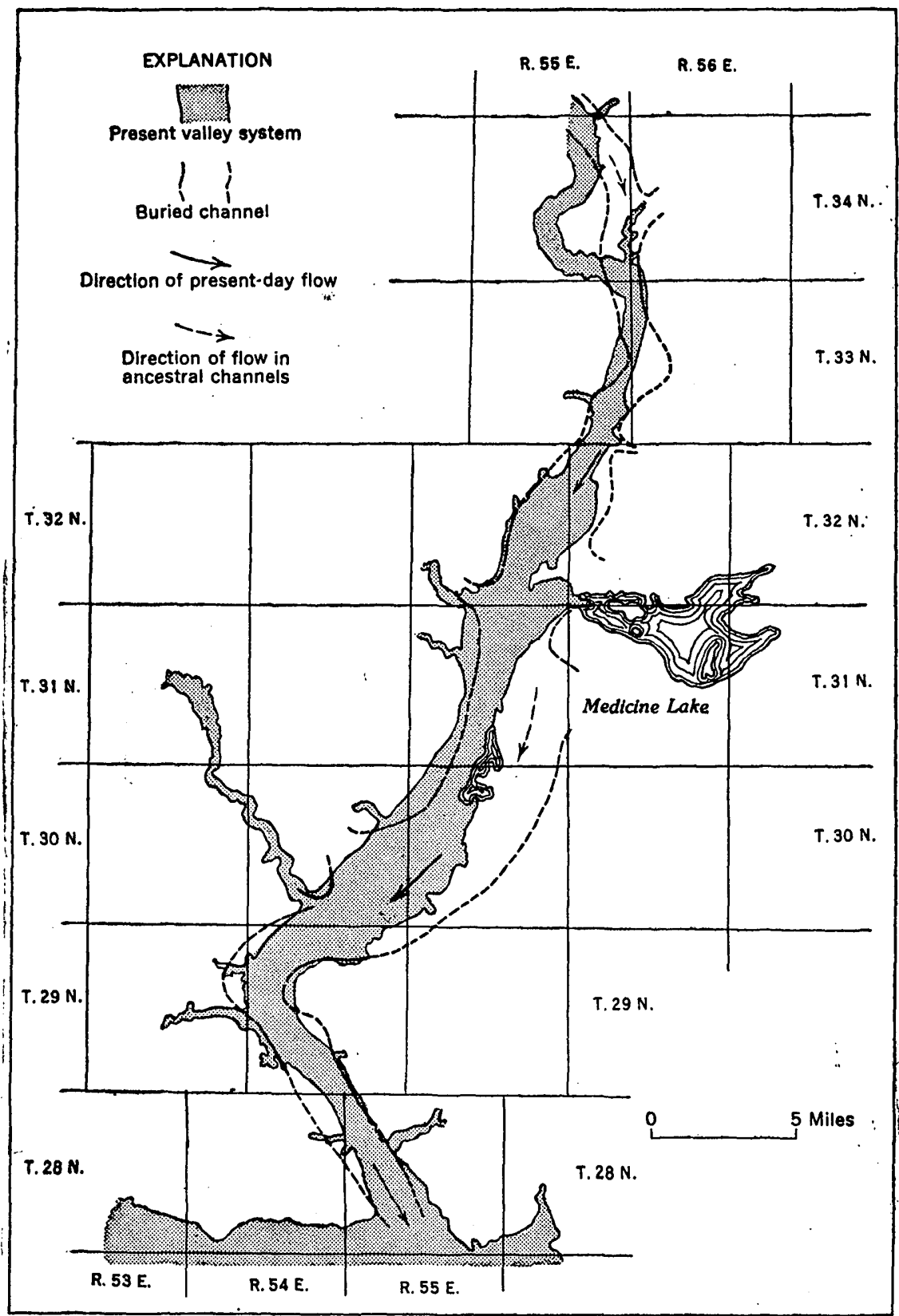

Fraone 12.-Probable relation of the ancestral Big Muddy channel (dashed lines) to the present valley of Big Muddy Creek.

A deep buried valley in bedrock east of Homestead and north of Froid, Mont., is indicated by a line of 10 drill holes south of Medicine Lake (fig. 13). The holes, about 1 mile apart, were drilled by the Ground Water Branch of the Geological Survey along a north line 


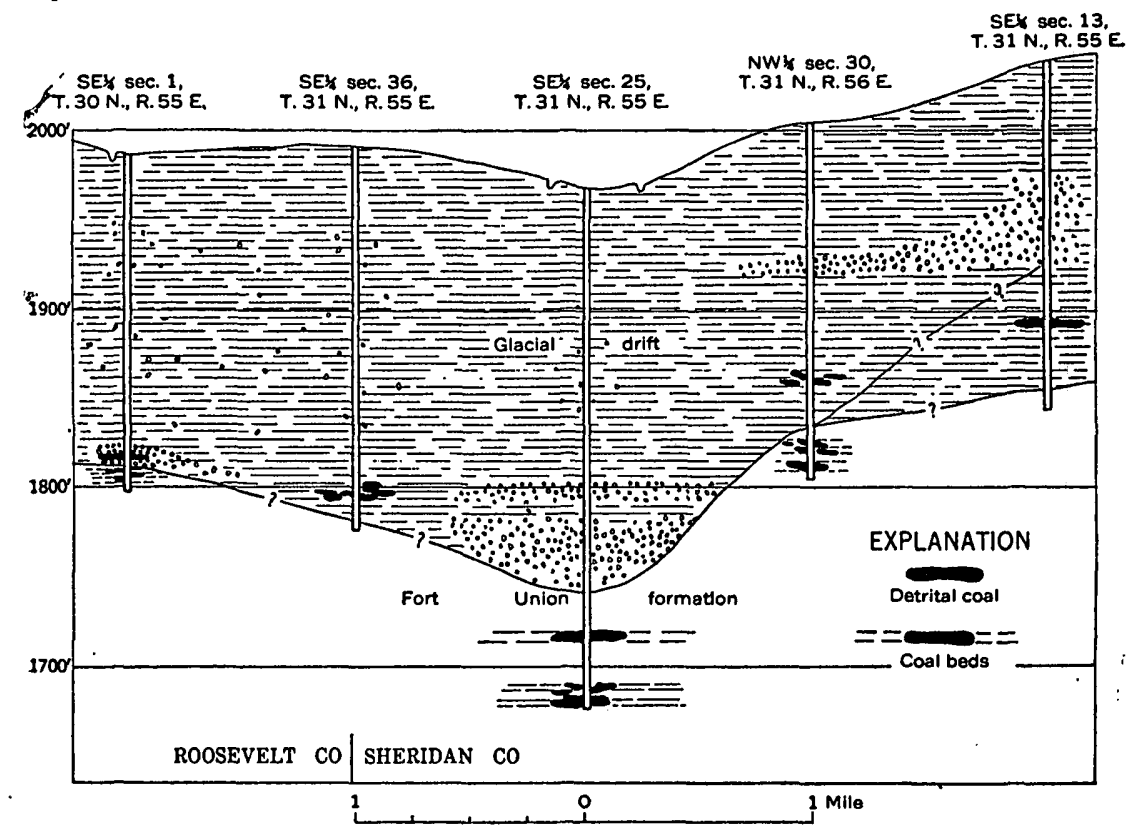

Fraorn 13.-A buried valley near Frold, Mont. Data for the cross section obtained from holes drilled in $\mathbf{1 9 4 7}$ by the Ground Water Branch of the Geological Survey.

parallel to Montana State Highway 16. Resistivity profiles along the same line also disclosed the valley (pl. 3). The buried valley, which is reflected as a low sag in the topography, may represent a meander of the ancestral Big Muddy Creek that flowed southward prior to the deposition of till, or it may represent the course of a totally different stream which flowed across this area in Pleistocene time and was subsequently buried by glacial drift. The deepest part of this valley underlies secs. 19 and 30, T. 31 N., R. 56 E., about 226 feet below the ground surface or at an altitude of about 1,744 feet. Farther south, in T. 28 N., R. 55 E., a line of holes drilled across the Big Muddy Creek valley by the Bureau of Reclamation has disclosed a buried valley with a bedrock floor at an altitude of about 1,689 feet. Between these 2 localities the altitude of the buried bedrock surface decreases about 55 feet in 17 miles or at a rate of about 3.2 feet to the mile. This suggests that the stream which cut the deepest part of the Big Muddy Creek valley could have cut the wide valley east of Homestead and north of Froid.

Plate 5, which was prepared by geologists of the Bureau of Reclamation, is a cross section of a possible dam site (pl. 1) and shows that the west side of the present valley in T. 28 N., R. 55 E., is composed of till underlain by a possible second till deposit and a thick deposit of sand and gravel. This sand and gravel extends as a layer of variable thickness from hole $A-10$ to some unknown point west 
of hole A-17. The deposit thickens considerably between holes A-10 and $A-14$ as a result of a valley which was cut in the bedrock. West of hole A-14, however, the sand and gravel are apparently on a higher surface which may represent a cut surface of the former valley. This layer of sand and gravel below till may be related to the tillburied sand and gravel deposits near Antelope.

At Antelope only one till sheet can be recognized overlying the sand and gravel deposits. Near the dam site (pl. 1), however, between drill holes A-17 and A-13, the drilling has disclosed what appear to be two till sheets, one above the other, separated by a thin lens of sand and gravel. The lower is logged as dark gray, the upper as brown; both tills are alike in all other respects. However, whether two till sheets are actually present in this locality is questionable; for the variation in color can be attributed to oxidation, and the sand and gravel may have been deposited englacially as a thin lens within the till.

Various interpretations of the geologic phenomena near the dam site are possible. One sequence is as follows:

1. An ice-marginal channel whose width was from some unknown point west of drill hole A-17 to about drill hole A-10 was formed, with the thalweg between drill holes A-13 and A-11.

2. Sand and gravel aggraded the entire valley.

3. At least one ice sheet overrode the sand and gravel.

4. As the ice wasted, the melt water was diverted into a course east of the former valley. The valley cut by these streams may have extended in width from drill hole A-10 to as far east as drill hole A-2.

5. Subsequent aggradation by melt water mantled the bedrock with a layer of clay, silt, sand, and gravel about 50 feet thick.

6. Big Muddy Creek then deposited a section of clay about 100 feet thick. The deposition was probably in response to alluviation of the Missouri River valley, to which Big Muddy Creek is graded. One hundred feet is not an excessive figure for the depth of alluvium in the Big Muddy Creek valley when compared with the depth of alluvial fill in the Missouri River valley. Drilling by U. S. Army Engineers at the Garrison dam site in central North Dakota revealed a thickness of about 200 feet of alluvium in the Missouri River valley.

SMOKE CREEK CHANNET

The most sharply defined channel in the western part of the area is the Smoke Creek channel. It trends southeastward through Tps. 30, 31, and 32 N., Rs. 52, 53, and 54 E. (fig. 8). In Tps. 31 N., Rs. 52 and $53 \mathrm{E}$., the channel turns abruptly east for about 4 miles before it once again resumes its southeasterly course. For most of its length the valley is about one-fourth mile wide, although locally twice or half that. Smoke Creek, a perennial stream about 10 feet wide, meanders 
across the broad, even valley floor to empty finally into Big Muddy Creek. Much of the channel, which in places is eroded in bedrock, is floored with outwash that is locally covered by postglacial alluvium less than 5 feet thick.

Terrace deposits that average 10 feet in thickness are found at 3 different levels-10, 20, and 45 feet-above the flood plain. The sand and gravel in most places lie on till, but locally they overlie bedrock. They probably are remnants of former outwash-channel fills which were dissected by later melt water.

The abrupt change in the course of the channel may have been due partly to the configuration of the buried topography. As bedrock is exposed on the divides, and as till extends down to, and below, the present flood plain along the greater part of the valley of Smoke Creek, it seems likely that the present course of the stream coincides closely with the preglacial course.

Smoke Creek valley was overridden by ice and partly filled with till. Subsequently it was deepened by glacial melt water and floored with glaciofluvial debris. However, because of the exposure of till( ?) along Smoke Creek, in sec. 20, T. 30 N., R. 54 E. (fig. 6), a more complex history than for most of the other channels in the area is suggested.

SMALL CHANNELS NEAR SMOKE CREEK

During the wasting of the ice which lay astride the Smoke. Creek area, stagnant blocks of ice occupied the valleys and extended across the upland. Much of the surface runoff and glacial melt water was diverted along marginal courses. In some places the streams flowed on ice; elsewhere they flowed on land. These latter courses are now marked by sand- and gravel-filled outwash channels that trend generally southwestward from the southwest rim of the Smoke Creek (pl. 1) valley and seem to record stages in the gradual shrinking and retreat of the ice from the area. One such channel crosses sec. 21, T. 31 N., R. $53 \mathrm{E}$., another is in sec. 22 of the same township, and a third is along the W $1 / 2$ sec. 2 , T. 30 N., R. 53 E. The most prominent of these, however, is the channel which trends southwestward across T. 30 N., R. 53 E., and then turns abruptly southeastward in sec. 4, T. 29 N., R. 52 E. Connecting these southwestward-trending channels are a series of southeastward-trending tributary channels that follow the regional slope of the land. Examples of such connecting channels are found in secs. 3, 8, 17, 29, and 30, T. 30 N., R. 53 E., and also farther south.

Another way in which these small channels might have formed is that large isolated blocks of the stagnating ice mass remained on the uplands. A series of marginal and radial channels would have formed adjacent to these ice blocks. The radially arranged channels that head in the upland whose center is sec. 31 , T. 31 N., R. 53 E., may have formed in this manner. 
DOWD CHANNEL

The trend of the Dowd channel is southwestward, normal to the regional slope of the land, suggesting that it, like many of the other channels, was formed marginal to the ice. At its northeast end, its floor is about 20 feet above the floor of Smoke Creek. It is likely that the Dowd channel was cut primarily by water escaping from a glacially dammed lake in the Smoke Creek valley. The wind gap at the head of the Dowd channel is located where the Smoke Creek channel bends eastward in T. 31 N., R. 52 E. From there the channel drains southwestward and passes out of this area at the west edge of T. 30 N., R. 52 E. (fig. 8).

Till underlies the outwash of the Dowd channel and extends unbroken into the early. Wisconsin(?) till that veneers the uplands. Narrow, elongate terraces, most of which are dissected remnants of former outwash fill, now flank the channel. In sec. 8, T. 30 N., R. 52 E., a crevasse filling is overlapped by the outwash which forms the terrace deposits; here the channel is confined by the crevasse filling. In sec. 20 , T. 30 N., R. 52 E., another crevasse filling locally deflected the course of the melt water southwestward.

It seems certain that the channel existed before the advance of the early Wisconsin(?) ice and that it was buried beneath that ice. Subsequent wasting of the ice freed the channel, and it was at this time that most of the contained outwash was deposited. In some places ice-contact deposits that locally deflected the melt water were formed, with the result that outwash now overlaps these deposits. Subsequently the outwash was eroded to form the present terrace surfaces. Possibly these glaciofluvial phenomena are attributable to the advance and wasting of the early Wisconsin (?) ice.

\section{SPENCER CHANNEL}

Another of the channels formed when ice blocked the valley of Smoke Creek was the Spencer channel, a broad, one-half-mile-wide drainageway originating in the northeast corner of T. 30 N., R. 53 E. (fig. 8). It can be traced as a shallow outwash-floored valley between low banks of till as far south as secs. 13 and 14 of the township. South of that point the outwash spreads in a broad, fanlike mass, with the coarser material at the apex. The southeast edge is truncated by the valley of Smoke Creek and hangs above the flood plain of Smoke Creek. A meander scar in secs. 29 and 30, T. 30 N., R. 54 E., shows several outwash-terrace surfaces. The wind gap at the head of the channel, in secs. 11, 12, T. 30 N., R. 53 E., is 40 feet above the present floor of Smoke Creek and exposes a cross section of the floor of the outwash body. The coarse sand and gravel deposit, about 20 feet thick, is crudely bedded and sorted, rusty brown, and seems to have been derived in large part from the Flaxville gravel. However, consider- 
able Canadian Shield material is included. The sand and gravel rest on Fort Union strata.

For most of its length the floor of the channel is remarkably even, with only a little evidence of dissection. Near its south end valleys have been cut through the outwash and into the underlying Fort Union formation. Although due in part to erosion by postglacial tributaries of Smoke Creek it seems likely that late melt water also dissected the channel deposit. In some places these streams merely cut shallow valleys. The two valleys in secs. 13 and 14, T. 30 N., R. $53 \mathrm{E}$., are of this type. Elsewhere these later streams were able to cut a series of terraces in the outwash. Presumably, as the early Wisconsin (?) ice continued to melt in the valley of Big Muddy Creek, the base level for the melt-water streams was successively lowered, and new, lower channels were developed. These channels were cut in the outwash deposits, which were dissected by still later melt-water streams. Thus, a series of terraces was formed. With the complete disappearance of the ice the valley of Smoke Creek was again exposed. Subsequently its floor was aggraded by outwash derived from the melting of Mankato ice lying north of this region. Postglacial aggradation has covered this outwash with alluvium.

\section{Davis Chan NeI}

The Davis channel, the major tributary channel of the Smoke Creek channel, trends southwestward and at one time probably acted as a diversion channel for the ponded water of Wolf Creek (fig. 1). It joins the Smoke Creek channel (fig. 8) at grade in the middle of $\mathbf{T}_{\mathbf{a}}$ 31 N., R. 53 E., at the point where the Smoke Creek channel resumes its southeasterly course. The Davis channel heads in a wind gap 80 feet above the floor of the Wolf Creek channel, north of this area.

Throughout its length the Davis channel maintains a width of about one-half mile. A small unnamed stream flows along its east edge. A kettle, almost as wide as the valley floor, breaks the smooth evenness of the flood plain directly north of this area. Commonly a thin veneer of alluvium mantles the outwash, which is well exposed along the stream bed of Smoke Creek in sec. 16, T. 31 N., R. 53 E. Till forms the valley walls and extends down to and below the flood plain.

The southwestward-trending course of the Davis channel almost normal to the regional slope of the land implies that the channel was formed marginal to the ice. Possibly it represents a widened and deepened preglacial tributary of Smoke Creek. When ice blocked southeastward-flowing Wolf Creek during early Wisconsin(?) time, the ponded water spilled across the divide into the valley of the preglacial tributary and widened and deepened the valley to form the Davis channel. A readvance of the ice deposited the till that 
mantles the sides of the channel. This was later buried under outwash as the ice wasted away.

LAKE CREEK OHANNEL

Drainage through most of the outwash channels was southward, but the Lake Creek channel probably drained eastward. The channel extends eastward from the valley of the Poplar River (fig. 1) to the Big Muddy Creek channel. Within this area most of its course is across the middle of T. $29 \mathrm{~N}$., R. $53 \mathrm{E}$. (fig. 8). The channel is relatively undissected near its southwest end, which is about 20 feet above the present flood plain of the Poplar River. Eastward the channel has a sinuous course across the south halves of T. 29 N., R. 52 E., and T. 29 N., R. $53 \mathrm{E}$. The outwash that filled the eastern part of the channel has been dissected by the present Lake Creek, exposing underlying till. Farther upstream, however, the outwash remnants broaden and coalesce until they form a continuous layer of sand and gravel across the channel floor.

It seems likely that the Poplar River valley at one stage, possibly early Wisconsin(?), was dammed by a block of ice and the river temporarily diverted to form the Lake Creek channel as a diversion channel. This channel was in turn blocked, most likely by an ice mass in the Big Muddy Creek channel, and the water impounded. A spillway on the south edge of the lake so formed probably existed in secs. 13, 14,23 , and 24 , T. 28 N., R. 52 E., about 4 miles west of this area. When the ice damming the Big Muddy Creek channel had wasted, the Lake Creek channel was used by the diverted Poplar River. This channel was finally abandoned when the ice blocking the valley of Poplar River had wasted, and the stream resumed its original course.

\section{LINEAR CHANNEL}

An unusually straight gravel-filled channel more than 25 miles long, the Linear channel, extends southwestward from sec. 3, T. 30 N., R. 56 E., to sec. 16, T. 28 N., R. 53 E., and beyond (fig. 8). Its continuity is interrupted by the broad valley of Big Muddy Creek, and it is concealed in the southwest corner of T. 30 N., R. 55 E., beneath dune sand which covers the southern part of this township and much of the northeast corner of T. 29 N., R. $55 \mathrm{E}$.

Northeast of the Big Muddy Creek valley the channel floor slopes southwestward; west of the Big Muddy Creek valley it slopes northeastward. The highest point, near its southwest end, is at an altitude of about 2,230 feet; the lowest, in sec. 30, T. 29 N., R. 54 E., is at 2,040 feet. The fall, thus, in about 7 miles is 190 feet or slightly more than 27 feet per mile.

The channel is about 100 feet wide, although locally it narrows to half that. Its walls are mantled with till, but postglacial dissection 
has exposed the underlying Fort Union formation in some places. Along certain segments of the course of the channel, however, the topography inverts and the channel floor caps a ridge, as in sec. 30 , T. 29 N., R. 54 E. The channel floor normally consists of unconsolidated sand and gravel, concealed in places by a thin veneer of alluvium. In some localities the smooth surface of the fill gives way to a series of irregular sand and gravel hummocks and knobs. The gravel consists of rust-brown well-rounded quartzite and chert pebbles similar to the Flaxville gravel, with smaller amounts of angular limestone, dolomite, granite, and gneiss pebbles derived from the Canadian Shield. The size range is variable, although in general the average pebble is one-fourth inch in diameter.

The presence, within the fill, of Canadian Shield material and several faint, shallow, closed depressions, probably kettles, strongly suggests a glacial mode of origin for the Linear channel. Moreover, glacial boulders as large as 2 feet in diameter are scattered across the channel floor.

The channel crosses all normal drainage lines except in secs. 25, 35, and 36, T. 29 N., R. 53 E., and sec. 30, T. 29 N., R. 54 E., where it coincides with, or parallels, the present drainage.

This channel deposit is unusual and difficult to explain. Possibly it is an ice-contact feature, as indicated by the local inversion of the channel to a gravel ridge, the presence of kettles and glacial boulders in the channel, and the composition of the gravels. It may reflect a buried valley whose alinement was determined by a fault, or it may be the result of drainage through an unusually long and straight crevasse in the glacier.

\section{MANKATO CHANNELS}

Most of the outwash channels in the part of the Smoke CreekMedicine Lake-Grenora area once covered by Mankato ice (pl. 4) were probably formed during the Mankato substage. However, definite evidence to establish the exact age of the channels is lacking. As the till that veneers the channel walls and some of the channel floors can be traced unbroken into the Mankato till which forms the uplands, it seems likely that some of the channels were in existence before the Mankato ice buried them. As many of these till-surfaced channel's are at some angle to the regional slope of the land, an ice-marginal origin is implied. Some may have been formed during halts in the withdrawals of pre-Mankato ice sheets. Others may have formed as ice-marginal channels during halts in the advance of the Mankato ice (p. 20). All the channels are floored with outwash, probably of Mankato age (p. 26).

COALRIDGE OHANNEL

The Coalridge channel (fig. 8) is an elongate, narrow, outwashfilled valley about 3 miles west of the Dagmar channel for most of 
its length. Most of its course is normal to the regional slope, suggesting an ice-marginal mode of origin. This channel is remarkably straight for most of its length and generally is about one-fourth mile wide, except that locally till constricts it to less than one-eighth mile (sec. 14, T. 34 N., R. 57 E.). It is graded to a kame terrace on the west side of the Dagmar channel (center of the west side, T. 33 N., R. $58 \mathrm{E}$.$) .$

Although the channel trends southwestward, several sharp bends occur near its south end (fig. $14 C$ ). There the channel turns southeastward, then southward, then northeastward for about 11/2 miles, then southeastward again down the regional slope of the land. These reversals further indicate that ice controlled the course of this channel.

A thin layer of mixed alluvium and colluvium generally conceals most of the outwash sand and gravel of the channel. This mantle is about 6 inches thick at the north end of the channel and about 2 feet thick near the outlet. The outwash consists of unconsolidated sand and gravel ranging in size from fine-grained sand to small pebbles about one-quarter inch in diameter. Limestone and dolomite pebbles predominate in this channel as in the others. Data are not available on the thickness of the fill.

Numerous marshy kettles, partly veneered with alluvium, are scattered along the channel; an extensive one is in sec. 14, T. 34 N., R. 57 E., and another is in sec. 34, T. 34 N., R. 57 E. No perennial stream drains the channel, although the valley walls have been furrowed by countless rivulets.

It seems likely that this channel was formed prior to the Mankato ice advance, and perhaps even before the early Wisconsin(?) ice. Probably it acted as an effective barrier to the Mankato ice. I interpret this channel to represent the northwest extent of the Mankato ice. The till mantling the west valley wall can be traced unbroken into the early Wisconsin(?) till that forms the uplands west of this channel. In a like manner, till forming the east valley wall can be traced eastward into Mankato till. Different ages for the till sheets is further suggested by the drainage patterns developed on both valley walls. Integrated dendritic-drainage patterns are developed on the till northwest of the valley. The streams are long, have broad valleys, and reach far into the upland. Although there are also drainage lines southeast of the valley, they are neither as well developed nor as extensive. Moreover, the kettles that are so numerous southeast of the channel continue to increase in number eastward, whereas only a few kettles can be found west of the channel.

Possibly the early Wisconsin(?) ice overrode and buried a preexisting valley and deposited a layer of till. Before the advance of the Mankato ice, well-developed drainage patterns were formed 
on both sides of the till-surfaced channel. When the Mankato ice finally advanced into this area, it moved across the channel, but it may not have been able to surmount the northwest valley wall. Hence, with the melting of the ice, a morainal topography was developed southeast of the channel in contrast to the stream-dissected topography northwest of the channel.

Kame-terrace remnants along the northwest side of the valley (p. 50 ), and two tributary diversion channels are further evidence of this history. One kame-terrace remnant straddles the section line between secs. 11 and 12, T. 34 N., R. 57 E.; other kame-terrace remnants can be seen farther south in the same township in secs. 27, 28,33 , and 34 .

Two distributary diversion channels lead southeastward from the Coalridge channel (fig. 14C). One, the North diversion channel, is north of Coalridge and trends southeastward across secs. 5, 6, 8, 9 , and 16, T. 34 N., R. 58 E. The other, the South diversion channel, is south of Coalridge and crosses secs. 26,27 , and $33, T$. 34 N., $R$. 57 E., and secs. 1 and 2,T. 33 N., R. 57 E.

A plausible sequence of events in the development of the Coalridge channel, that involves at least two ice advances, is illustrated in figure 14 .

The South diversion channel is more clearly delineated than the North diversion channel. The north end of the sand- and gravelcovered floor of the South diversion channel is about 10 feet higher than the floor of the Coalridge channel, and the south end about as high above the Dagmar channel. Steep and well-defined walls of till flank the head of the South diversion channel; along the remainder of the channel, however, the walls are more subdued and merge into the surrounding topography. The outwash of the South diversion channel overlies till and is well exposed in a gravel pit in the center of the west side of sec. 6, T. 33 N., R. 58 E., and at the channel's south terminus, in the same section. A postglacial stream has eroded headward from the Dagmar channel, and remnants of the outwash now appear as terraces along its course. Toward the head of the channel, however, beyond the head of this postglacial stream, the outwash surface is undissected.

Centering about the north half of sec. 34, T. 34 N., R. 57 E., is a circular till-covered mound whose crest is about 60 feet above the surrounding ground surface. The north slope of the hill forms part of the south wall of the South diversion channel. Bedrock is not exposed, so this prominence may be an unusually thick accumulation of till. If so, the till, or the ice that deposited the till, may have diverted the water in the channel southeastward.

I believe that as the block of Mankato ice which dammed the Coalridge channel melted, much of the water formerly escaping through 

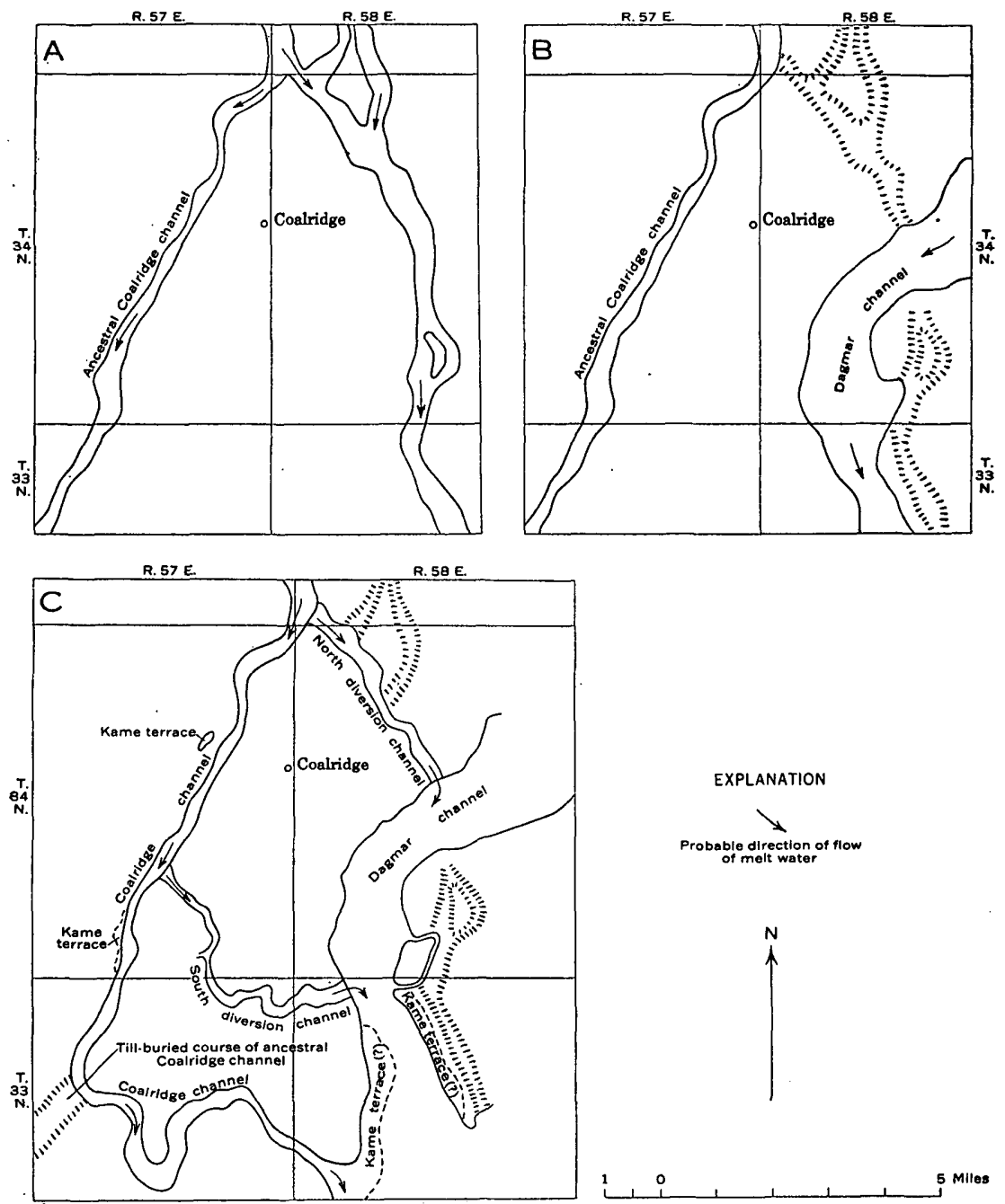

$$
\stackrel{N}{\uparrow}
$$

Fradre 14.-Channel development near Coalridge, Mont. A, Ice-marginal channels, floored with sand and gravel, formed prior to the advance of early Wisconsin (?) ice. $B$, Tillburied (indicated by hachures), and till-free channels were exposed after withdrawal of early Wisconsin(?) ice; a new channel, the Dagmar, has been cut across the former channel, which now shows as a till-buried, elongate, sinuous sag. $C$, Channels near Coalridge, Mont., after the withdrawal of the Mankato ice. Kame-terrace deposits along the Coalridge channel probably represent the northwest margin of a Mankato ice lobe. Parts of former till-buried channels were reused by melt water from Mankato ice and were floored with sand and gravel: New diversion channels were formed as a result of ice dams in the ancestral Coalridge channel. The southern part of the ancestral Coalridge channel now is a till-surfaced trough (indicated by hachures).

the North diversion channel began to follow a new route farther south, through the South diversion channel. Once established, the diverted water was quick to erode the till and thus form the South diversion channel (fig. 14C). 


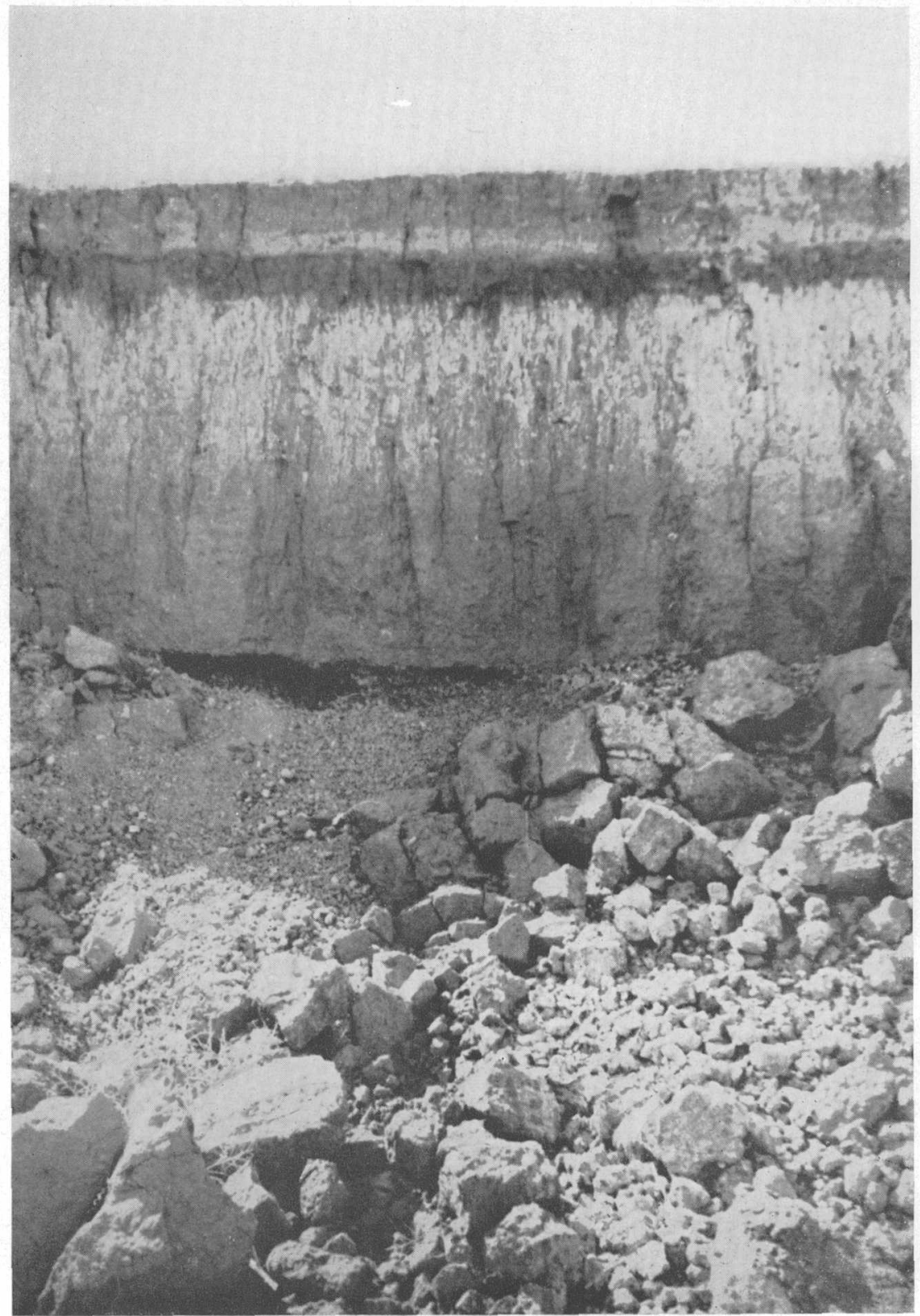

CONTACT BETWEEN GRAVEL OF OUTWASH CHANNEL AND OVERLYING TILL

Exposure showing the contact between the gravel of a former outwash channel and the overlying till. The gravel is very permeable and could serve as a subsurface channel for water. The till is relatively impermeable. Datk band in till is present soil profile; overlying light-colored material is debris. (Gravel pit in Montana, SE $1 / 4$ sec. 18 , T. 33 N., R. 57 E.) 
As soon as the block of ice that was diverting the water into the South diversion channel had wasted sufficiently, the water returned to the original course of the original ice-marginal channel west of Coalridge and abandoned the South diversion channel.

The final diversion of the water was probably along the horseshoeshaped curve near the south end of the channel (fig. 14C). Here, the abrupt change in direction of the ice-marginal channel west of Coalridge suggests that ice lay across the southern part of the channel. This is further shown by the presence of sand and gravel deposits below till (pl. 6).

None of the resistivity profiles cross the Coalridge channel; site 1-D-1 of profile D (pl. 3) is about 2 miles south of the horseshoeshaped bend that marks the southern part of the channel. Edwards (1951) interprets the electrical resistivity measurement at site 1-D-1 as indicating about 150 feet of sand and gravel capped by till. This buried sand and gravel may represent an ancestral Dagmar channel or some preglacial drainageway completely concealed by the glacial deposits.

COTTONWOOD CREEK CHANNEL

The steep-sided valley of Cottonwood Creek (pl. 1), 1/8 to $1 / 4$ mile wide, trends southwestward with its floor about 125 feet below the upland. The valley is uninterrupted from its junction with the Scorio Valley channel in the northeast to its terminus in a large alluviated flat in the southwest in sec. 20, T. 32 N., R. 59 E. beyond the limits of the area of figure 8. A veneer of alluvium conceals the outwash sand and gravel.

The course of Cottonwood Creek is at an angle to the regional slope, which indicates that it probably formed as an ice-marginal channel.

The land north of Cottonwood Creek is relatively undissected and is characterized by knob and kettle topography. South of the creek, however, these glacial features are lacking, and the surface has been dissected into gentle hills and spacious, sinuous valleys. In general, the northward-flowing tributaries of Cottonwood Creek are well developed, have low gradients, and extend far into the upland to. the south. Conversely, the southward-flowing tributaries to Cottonwood Creek are poorly developed, have steep gradients, and are relatively short.

The sharp contrast in topography and drainage north and south. of Cottonwood Creek suggests that till of two ages flanks the valley: youthful (Mankato) till on the north and more mature (early Wisconsin(?)) till on the south. I interpret Cottonwood Creek to. represent the southernmost extent of the Mankato ice sheet in this area. Kame terraces are found along parts of both valley walls of Cottonwood Creek, as described on page 50. 
The Dagmar channel is one of the major outwash channels in this area (fig. 8). It was first described by Beekly (1912, p. 323), who was so impressed by its width and length that he thought it might represent the preglacial course of either a tributary to the Missouri River or of the Missouri itself.

The channel is about $11 / 2$ miles wide, although it ranges locally from less than a mile to as much as $21 / 2$ miles in width. The channel trends northeastward toward a sag in the ridge capped by the Max moraine. Near its southwest end the channel is occupied by Medicine Lake. West of the lake the channel is graded to the Big Muddy Creek channel. For most of its sinuous course the channel is occupied by a train of outwash flanked by till walls. However, near its head (close to Westby, Mont., north of this area) it shows evidence of having been confined by blocks of ice, for the sand and gravel deposits form a flat-topped ridge topographically higher than the adjacent till surfaces.

Near the head of the channel the gravel averages 1 inch in diameter, whereas at the south end the average size is $1 / 4$-inch. It is lithologically identical to that in the Stady and Grenora channels. Pebble counts show a preponderance of limestone and dolomite and a paucity of other rock types. Most of the pebbles range from round to subangular, but no appreciable contrast is apparent between the material near the head of the channel and that near Medicine Lake. The outwash is well bedded. In general, only scattered boulders dot the surface, but there are local concentrations of boulders, as along the west edge of the channel in sec. 4, T. 32 N., R. 58 E., south of Dagmar. These boulders, which are not only on the surface but are embedded within the outwash, were probably ice-rafted to the locality.

Numerous kettles, kettle lakes, and marshy areas pit the surface. All imply melting of buried or partly buried ice blocks. Some are surrounded by outwash; others, as in sec 3, T. 32 N., R. 58 E., are partly bordered by outwash and partly by till. The presence of the second type of kettle implies that the same block of ice was surrounded by both till and outwash. Further, the implication is that the till and outwash are of the same age, for if the outwash were younger, it would have filled the kettle. No stream of any size drains the Dagmar channel, so that the only alluvium is confined to the kettles and marshes.

The total depth of fill in the northern part of the Dagmar channel is unknown. A strong flow of ground water was found in most of the water wells at a depth of about 75 feet in unconsolidated sand and gravel. No wells northeast of Medicine Lake are known to have passed completely through this fill. 
Both the hole drilled in the center of the west edge of sec. 31, T. 32 N., R. 56 E., by the Ground Water Branch of the Geological Survey and that drilled by the Bureau of Reclamation in the center of sec. 31 , T. 32 N., R. 56 E., penetrated about 180 feet of sand and gravel.

It may be that the sand and gravel fill within the Dagmar channel does not correctly reflect the width of the subsurface part of the channel. The subsurface channel may be a relatively narrow valley whose course is suggested in only a general way by its surface expression.

Along parts of its course the Dagmar channel is flanked by terraces as much as 40 feet above the floor of the channel (p. 51). Numerous kettles dot the terrace surfaces, and ice-contact features are common. Many pebbles in the deposits are larger than in the outwash of the channel floor, although identical lithologically.

The Dagmar, Grenora, and Stady channels join near Brush Lake, Mont. (sec. 22, T. 33 N., R. 58 E.) ; the Stady and Grenora channels are graded to one another. Their confluence plain, however, stands as a terrace 20 feet above the floor of the Dagmar channel, which cuts across it. The failure of these three channels to meet at grade is puzzling. It may be that the Stady, Grenora, and Dagmar channels were formed contemporaneously and were graded to a former higher surface in the Dagmar channel that was subsequently largely removed by melt water. Another possibility is that the Dagmar channel was occupied by ice where the three channels join, and that the Stady and Grenora channel fills were graded to a kame terrace along the east edge of the ice.

The Dagmar channel is crossed by four resistivity profiles (pl. 3). Beneath sites E-2, C-5, and A-4 (all within the surface expression of the channel), the depth to bedrock ranges from 110 feet at E-2 to 155 feet at A-4. At site 1-D-2, however, the depth to bedrock is estimated to be 170 feet. Thus, if the resistivity interpretations are correct, there is a deepening of the channel here. Beneath site E-2, the channel fill apparently is sand and gravel. About 6 miles farther south at site 1-D-2, in about the same lateral position in the channel, the fill seems to be predominantly clay with only a veneer of sand and gravel. Still farther south, at sites $\mathrm{C}-4$ and $\mathrm{C}-6$, the channel seems to be partly filled with till, although midway between these sites, at $\mathrm{C}-5$, the fill seems to be sand and gravel. Farther west, sites A-1 and $A-4$ at the terminus of the channel also show a fill of sand and gravel. Near Medicine Lake both the Bureau of Reclamation and U. S. Geological Survey have substantiated by drilling the geophysical interpretation of the channel fill of sand and gravel, but the resistivity data at site A-1 indicates a depth of 135 feet (Edwards, 1951, p. 7), whereas drill holes nearby penetrated 180 feet. 
STADY CHANNEL

One of the most persistent outwash bodies is in the Stady channel. Elongate, narrow, and comparatively straight, its course can be traced for about 20 miles from sec. 28, T. 161 N., R. 100 W., in North Dakota southwestward to its junction with the Grenora and Dagmar channels in T. 33 N., R. 58 E., in Montana (fig. 8). The Stady channel, in the bottom of a wide topographic sag, is for the most part about $1 / 2$ mile wide, although at places it narrows to about $1 / 4$ mile and elsewhere widens to a mile or more.

Many kettles pit its surface. Locally the outwash forms a broad ridge of sand and gravel higher than the adjacent till surface. This suggests that at least along parts of its course the outwash was confined between wasting blocks of ice. Ice-contact faces, modified to some extent by subsequent erosion, are present locally. A well-preserved ice-contact surface is visible along the north edge of the channel in the NE1/4 sec. 32, T. 161 N., R. 101 W.

The outwash in the Stady channel is poorly sorted. Most of the material near the source is coarse-the pebbles average as much as 2 inches in diameter-whereas the pebbles are about $1 / 2$ inch in diameter near Brush Lake. Limestone and dolomite pebbles are the most abundant, granite and gneiss are also common; chert, quartzite, rhyolite, and other igneous and metamorphic rocks are present in about the same proportion as in the Mankato till. No wells or drill holes have penetrated the outwash of the Stady channel, but it seems unlikely that the fill exceeds 25 feet in depth; small springs at the edges of the various kettle lakes in the outwash are presumably fed by ground water perched on impermeable till beneath the sand and gravel.

Resistivity profile E-7 (pl. 3) crosses the channel near its junction with the Dagmar channel, but none of the sites are within the channel, although sites E-3 and E-4 flank it. The interpretation of data obtained at site E-4 indicates a veneer of sand about 23 feet thick, perhaps outwash of the Stady channel, overlying massive till estimated to be 137 feet thick. This buried sand and gravel indicated at site E-3 may represent either a pre-Mankato or a preglacial valley (fig. 14).

SCORIO VALLEY CHANNEL

Immediately east of Grenora and extending southeastward for about 13 miles is a $1 / 2$-mile-wide valley, floored with alluvium and underlain by outwash, known as the Scorio Valley channel (fig. 8.) In general, its course conforms to the southeastward regional slope of the land.

The valley is steep walled, with a flood plain about 200 feet below the surrounding upland. The flood plain is about $1 / 2$ mile wide, 
although locally it widens to $3 / 4$ mile. Till of Mankato age veneers the valley walls and passes below the alluviated flood plain in some places, implying that at least parts of the valley existed prior to the advance of the last ice. The nature of the former valley is indicated by logs of drill holes of the Bureau of Reclamation (fig. 9). Although the bedrock high shown by the drill holes is in sec. 8, T. 159 N., R. $102 \mathrm{~W}$. (pl. 1), the present drainage divide is near the northwest edge of section 15 and probably dates from postglacial dissection.

\section{GRENORA CHANNEL}

Some of the outwash in this area has been deposited as fans; the Grenora channel deposit (fig. 8), with its apex about one-half mile southwest of Grenora (sec. 1, T. 159 N., R. 103 W.) is a good example. The outwash is distinctly sorted and is coarsest at the apex of the channel, where boulders and cobbles are present; the degree of sorting and rounding improves with distance from the apex. Numerous kettles and kettle lakes pit the surface of the outwash, and such lakes as Twin Lakes (secs. 8 and 16, T. 159 N., R. 103 W.) and Horseshoe Lake (sec. 18, T. 159 N., R. 103 W.) were probably formed in this manner.

In the absence of extensive deep-well data, no general statement can be made as to the exact thickness of the outwash in this area; it is undoubtedly highly variable. Exposures near the flanks of the Grenora channel suggest that about 20 feet of outwash overlies impermeable till, but the outwash probably thickens toward the center of the channel.

Resistivity profile E (pl. 3) crosses the Grenora channel near its junction with the Dagmar channel (SE1/4, T. 33 N., R. 58 E.). In particular, sites E-5, E-6, and E-7 are of interest. Site E-6 apparently marks a deep channel filled with about 168 feet of sand and gravel, a middle layer of about 15 feet of till, and a top layer of about 4 feet of sand which probably represents outwash deposited in the Grenora channel. The lateral limits of the deeply buried channel seem to be at E-5 and E-7.

Two eskers rise above the surface of the channel. These are partly buried by outwash sand and gravel and hence are older. Their courses are shown on plate 1 .

Most likely the Grenora channel and the eskers were formed by the same ice sheet: the eskers formed beneath thin stagnant ice, gradual wasting of the ice uncovered them, and then outwash from the melting ice partly buried them. At the same time, melt water flowing on the main body of the ice probably seeped through crevasses to the base of the ice and was guided by the ice-buried topography into a preexisting channel whose course, at least in part, was probably collinear with Scorio Valley in sec. 7, T. 159 N., R. 102 W. With the escape 
of this heavily laden water beyond the ice, the Grenora outwash channel deposit was formed. As the overloaded subglacial stream emerged from beneath the ice it dropped much of its load, as shown by the size of the material at the apex of the outwash body, and then deposited the remainder in the form of a broad fan.

ZAHL CHANNEL

A broad irregular body of outwash occupies the Zahl channel in the center of a wide topographic sag along the east side of the area. The outwash begins as a 1-mile-wide band in about the center of T. $160 \mathrm{~N}$., R. $100 \mathrm{~W}$., and widens southward until it enters the broad valley of Little Muddy Creek (fig. 8). From this point southward, where it enters the valley of the Missouri River, the outwash plain maintains a constant width of about 3 miles. Along the east edge of T. $159 \mathrm{~N}$., R. 101 W., it is joined by the outwash which floors the Scorio Valley channel. Another outwash train joins it from the east near the west edge of T. 159 N., R. 100 W. The surface of the plain is gently undulating and slopes southward at about 10 feet per mile within the limits of the Smoke Creek-Medicine Lake-Grenora area. Numerous kettles, ranging from a few feet to several hundred feet in width and from 5 to as much as 50 feet in depth, are scattered across the surface of the outwash. Terraces and glacial stream channels are also found within the outwash plain. The gravel and sand of the outwash are typical of the other glaciofluvial deposits in this area.

Inasmuch as the outwash heads in Mankato drift, and in several places is at a higher altitude than the adjoining till, the outwash was probably deposited near the margin of the Mankato ice.

\section{EARIY WISCONSIN(?) ICE-CONTACT DEPOSITS}

The ice-contact deposits formed beyond the limits of the Mankato ice sheet (pl. 1 and p. 26) are considered to have been formed in contact with, and by melt water of, the early Wisconsin(?) ice.

\section{KAME DEPOSITS}

Relatively few kames are found in the western part of the area, in contrast to the concentration in the eastern part. The kames in the west half range in height from 30 to 50 feet and are steep sided, conical knolls of more or less stratified material which ranges from sand to glacial boulders. A cluster of small kames is in sec. 30, T. $28 \mathrm{~N}$., R. 55 E., and in sec. 25, T. 28 N., R. 54 E. Another kame, composed of stratified drift, is in sec. 26, T. 30 N., R. 53 E. All are crudely circular and all have small blocks of till and glacial boulders along their flanks. A few conical knobs veneered with till in sec. 5, T. 29 N., R. 53 E., may be kames. Another group of conical knobs, similarly veneered with till, straddles the township line between Tps. 29 and 30 N., R. 53 E., west of Smoke Creek. 
Most of the kames apparently formed as steep-sided fans at or near the margin of the early Wisconsin(?) ice. With the melting of the ice these deposits were left unsupported, and they collapsed to form conical mounds. Those kames(?) veneered with till may represent ice-contact deposits which were overridden by ice after they were formed. As they retain the conical shape typical of kames, it seems likely that they were frozen into a cohesive unit when the ice passed over them, and hence were not destroyed.

ESKER DEPOSITS

Only one early Wisconsin(?) esker has been found in the western part of the area, in contrast to the many Mankato eskers in the eastern part. The esker is in secs. 13 and 24, T. 28 N., R. 54 E. It is about 20 feet high, about 1 mile long, and trends southwestward. Material forming the esker ranges from sand to glacial boulders, and most of the sediments exposed are poorly sorted. Wedge-shaped blocks of till and glacial boulders mantle its flanks. Gravel for road material is obtained from a small pit at its south end.

\section{CREVASSE DEPOSITS AND TILL RIDGES}

Linear deposits of glaciofluvial material, found in close association with ice-contact deposits, have been identified as crevasse fillings by their straightness, which differentiates them from eskers and kames. Most of the crevasse fillings are narrow, straight, ridgelike deposits, seldom more than one-half mile long, composed predominantly of poorly sorted sand and gravel with numerous glacial boulders and blocks of till scattered throughout. The bedding is poor, and the texture changes abruptly both laterally and vertically. The deposits have uneven crestlines. In at least one locality (sec. 20, T. 30 N., R. $52 \mathrm{E}$.), the irregularity seems to be due to postglacial stream erosion. In general, however, the uneven crestlines reflect irregularities in the original constructional surface.

All the crevasse fillings are oriented southwestward. They were probably formed by melt water flowing over the ice and depositing sediment in crevasses which paralleled the direction of glacier flow. Englacial boulders and unstratified drift from the crevasse ice walls were probably added as the ice wasted.

Several well-developed crevasse fillings about 30 feet high evidently controlled the original course of the Dowd channel in secs. 8 and 20, T. 30 N., R. 52 E.

A few low ridges of till form small clusters in parts of the western half of the area, as in Tps. 29 and 30 N., Rs. 52 and 53 E., and farther east in Tps. 33 and 34 N., Rs. 56 and $57 \mathrm{E}$. These till ridges are about 10 feet high and about $1 / 4$ mile long. All are remarkably linear. Ridges similar to these are common in the eastern part of the area (pl. 1). 
The till ridges may be annual morainal ridges or crevasse fillings formed parallel to the ice margin.

MANKATO ICE-CONTACT DEPOSITS

All the ice-contact deposits within the margins of the Mankato ice sheet (pl. 1 and p. 26) are considered to have been formed by, and in contact with, Mankato ice.

KAME-TERRACE DEPOSITS

Kame-terrace deposits of Mankato age flank parts of three channels in the east half of the area-the Cottonwood Creek, Coalridge, and Dagmar channels (pl. 1). These terraces presumably formed between the valley walls and the Mankato ice masses in the center of the channels.

Cottonwood Creek channel.-Kame-terrace deposits are present along parts of both valley walls of Cottonwood Creek. Those along the south valley wall are at a higher elevation than similar terraces along the north valley wall (fig. 15). The surfaces and frontal slopes of these terraces are characteristic of ice-contact features, and blocks of till and large glacial boulders are embedded within the sand and gravel. The kame-terrace deposits that flank Cottonwood Creek contain abundant limestone and dolomite pebbles and relatively minor amounts of granite, quartz, quartzite, and chert. The material changes rapidly in texture; the average pebble diameter is about one-half inch. Exposures of the bedding show steep angles of dip, suggesting slump; blocks of till can commonly be found embedded within the sand and gravel. In a gravel pit (sec. 1, T. 158 N., R. 103 W.) south of Grenora, bedding with dips of as much as $60^{\circ}$ have been measured. Evidently, as the ice underlying the deposit shrank, the horizontally bedded sand and gravel slumped toward the center of the valley. The fact that the terrace surfaces are not matched implies an ice-contact mode of origin.

Figure 15 offers a possible explanation of the origin of the kame terraces. The valley evidently was cut prior to the glacial period in which the kame terraces were formed.

Coalridge channel.-Probable kame terraces of Mankato age flank the west side of the Coalridge channel but are missing along the east side. In contrast to the kame terraces developed along the Cottonwood Creek channel, exposures of the Coalridge channel kame-terrace deposits are generally small, discontinuous, and rest on early Wisconsin (?) till. The deposits are at various levels, which may indicate deposition during successive stages in the wasting of the ice. The bedding is indistinct, and the pebble size varies widely, as exhibited in exposures in sec. 33, T. 34 N., R. 57 E. The lithologic composition of the terrace deposits is similar to that of other outwash in the 
N.

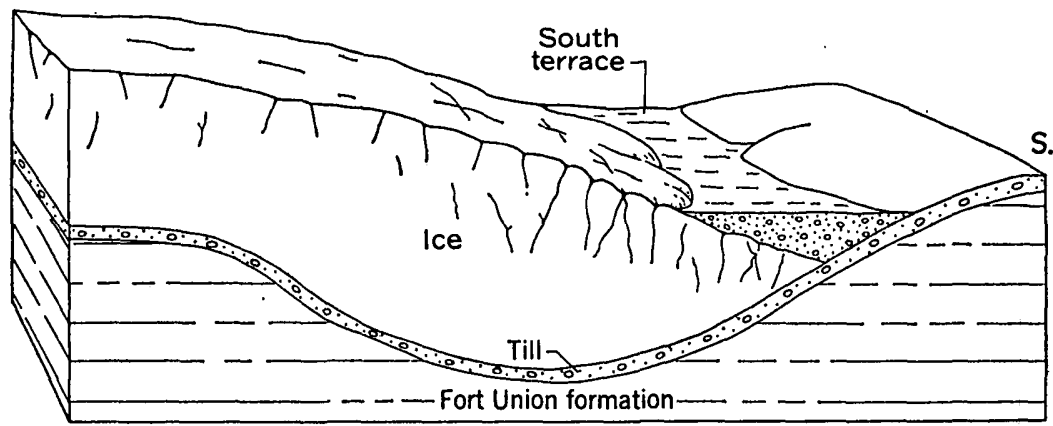

1. Ice front against south wall; deposition of south terrace

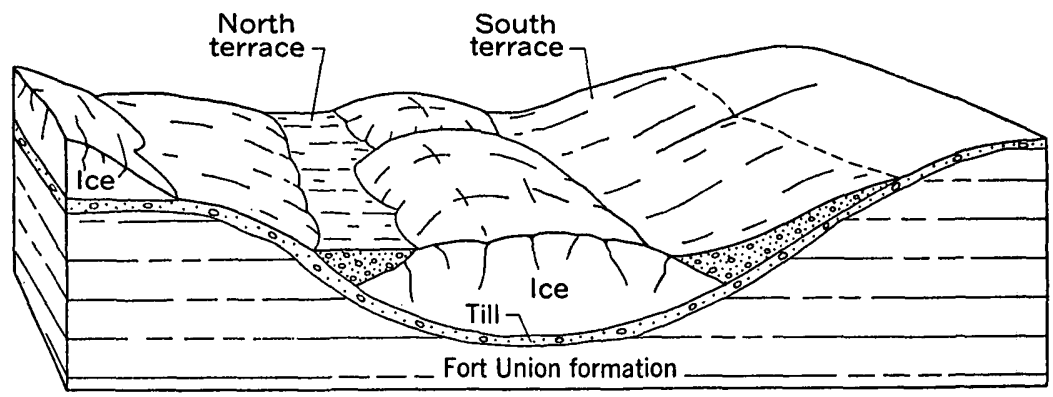

2. Thinning and stagnation of ice front; ice blocks left in valley; deposition of north terrace

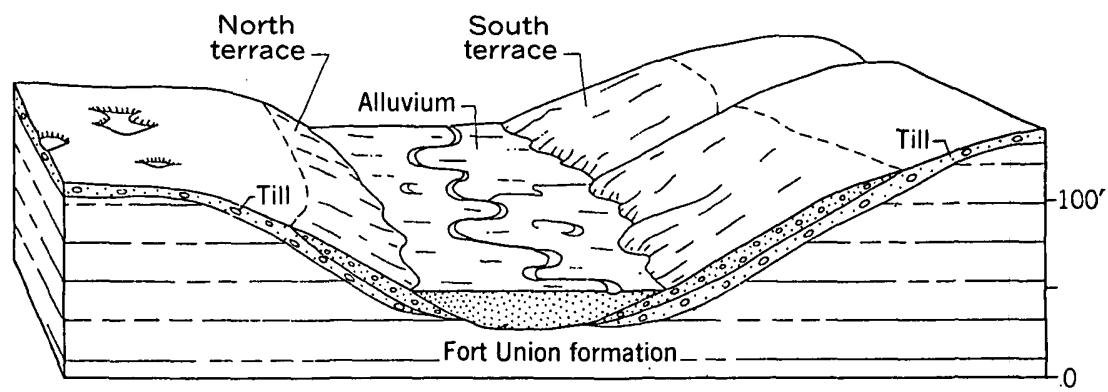

3. Final disappearance of ice; alluviation of valley bottom

0

1 Mile

FraUre 15.-Three stages in the development of kame terraces along Cottonwood Creek.

area; a predominance of limestone and dolomite with minor amounts of quartz, quartzite, chert, and igneous rocks.

Dagmar channel.-It is uncertain whether the extensive terraces flanking the Dagmar channel are kame terraces or remnants of a 
former continuous valley fill. The terrace surfaces range from about 3 feet above the channel floor in T. 34 N., R. 58 E., to about 40 feet in T. 33 N., R. 58 E.; most, however, are about 20 feet above the channel floor. In general the terrace remnants are composed of unconsolidated and fairly well sorted outwash. Although included blocks of till have not been observed, good sections through the terrace deposits are rare. Scattered across the surface of the terraces, however, are features of ice-contact origin. The many kettles and marshes-imply former buried ice blocks. Glacial boulders litter the surface and are embedded in the outwash. None of the terrace escarpments exhibit characteristic ice-contact faces, but these may have been destroyed. The terraces match along each side of the valley. It may well be that the Dagmar channel was blocked by remnants of a wasting ice mass. The melt water flowed around these ice blocks and formed kame ter. races at equal altitudes along the valley walls. Such an ice block may have lain at the junction of the Stady, Grenora, and Dagmar channels. When the ice melted the subsequent discordance in grade between the three channels resulted (p. 45).

\section{KAME DEPOSITS}

The kame deposits of Mankato age are generally found in clusters associated with other ice-contact features representative of a stagnant ice mass. For example, kames and eskers are closely associated north of Medicine Lake. All the kames are conical in shape, crudely circular at the base, and generally 30 feet or less in height, although a few exceed 50 feet. Glacial boulders and blocks of till are embedded in the sediments and also on the flanks. Limestone and dolomite are the dominant rock types, but small amounts of other rocks of the Canadian Shield are also present. The sediments are poorly sorted, and the bedding dips steeply.

A conical knob covered with till in the northwest corner of sec. 24, T. 32 N., R. 56 E., resembles the early Wisconsin(?) till-covered kames (?) and probably was formed in much the same manner.

The ice-contact features concentrated in the general area north of Medicine Lake represent deposits formed at the very southwest margin of the Mankato ice.

\section{ESKER DEPOSITS}

Most of the esker deposits of Mankato age in the eastern part of the Smoke Creek-Medicine Lake-Grenora area appear as narrow, elongate, sinuous ridges of stratified drift with uneven crests and smooth, steep slopes. Many of the crests are broad and pitted with kettles (pl. 7). All the eskers trend southwestward, paralleling the presumed direction of glacier movement.

The eskers range in height from about 10 feet to about 80 feet. The bedding parallels the sides, as a result of slumping. A crude sorting 
of the materials has evidently occurred: the coarse materials are more abundant at the northeast ends of the eskers and finer grained sand at the southwest ends. This is shown well by the esker which begins in sec. 8, T. 160 N., R. 100 W., and ends in section 17 as a widespread fan consisting of a mixture of fine sand and small pebbles.

Almost all the eskers have patches of Mankato till on their crests or flanks. The till is in wedge-shaped bodies that thin toward the crest. Glacial boulders are scattered over the crests and flanks and are interspersed in the sand and gravel. Most of the eskers were probably formed subglacially, but some, which have wide gaps in them, may be englacial in part. The esker which is interrupted by Horseshoe Lake (sec. 18, T. 159 N., R. 103 W.) and by the south lake of the Twin Lakes (secs. 9 and 16, T. 159 N., R. 103 W.) is one of the most prominent and best developed in the area. It begins about 1 mile west of Grenora in sec. 11, T. 159 N., R. 103 W., continues for about 6 miles to the southwest, and ends in sec. 23, T. 33 N., R. 58 E. The esker is uneven and discontinuous; its average height is about 35 feet. Kettles pit its crest, which averages 75 feet in width, in sec. 17, T. 159 N., R. 103 W., and glacial boulders are scattered over its surface. Younger outwash has partly buried its base, especially near its west end (p. 47).

Near the town of Alamo, N. Dak., in sec. 22, T. 159 N., R. 99 W., and northeast of Cottonwood Lake, is another esker, which is about 8 miles long. This esker is for the most part less than 10 feet above the adjacent ground surface. In many places its course is braided and discontinuous. Younger outwash has partly buried it, although till mantles its flanks and crest along parts of its length. Gravel pits in the esker furnish most of the sand and gravel used for road metal in this vicinity.

A smaller esker, near Kettle Lake, N. Dak., in secs. 8 and 9, T. 159 N., R. 100 W., attains a maximum height of about 65 feet. Its crestline is broad and uneven; in a few places the esker is discontinuous. A road cut between secs. 3 and 4, T. 159 N., R. 100 W., reveals both the sand and gravel of the esker and an overlying wedge of till. The till, rather thick on the flanks of the esker, thins out rapidly toward the crest. The sand and gravel is crudely stratified, and the bedding dips away from the crest at a high angle.

CREVASSE DEPOSITS AND THL RIDGES

The crevasse fillings of Mankato age are similar in all respects to those of early Wisconsin(?) age. In general, they are narrow, ridgelike deposits, which range in length from a few hundred feet to as much as one-quarter of a mile. They are composed of poorly sorted sand and gravel with included boulders and angular blocks of till. 
Uneven crestlines are common. All are oriented southwestward and thus reflect the direction of glacier movement.

Several small ridges about 25 feet in height, interpreted to be crevasse fillings, are found in North Dakota in sec. 19, T. $160 \mathrm{~N}$, R. $99 \mathrm{~W}$., and in Montana in sec. 18, T. 32 N., R. 59 E., and secs. 24 and 28, T. 32 N., R. $58 \mathrm{E}$.

Low ridges (pl. 8) of till cover much of the eastern part of the area. They commonly are oriented southeastward, normal to the direction of ice movement, but in many localities these ridges are arranged in lobate patterns, as in Tps. 161 N., Rs. 97 and 98 W. Most are about 10 feet above the surrounding ground and several extend in a straight line for distances as great as 2 miles. Their average length, however, is about one-quarter mile. They may be either annual morainal ridges deposited at the margin of wasting ice, or, more likely, crevasse fillings which were formed parallel to the margin of the ice.

\section{RECENT DEPOSITS}

Recent deposits in the area include alluvium, colluvium, dune sand, and stream-terrace deposits (pl. 1). These postglacial deposits differ in thickness and lie unconformably on older formations.

Alluvium.-Alluvium mantles the outwash in most of the major outwash channels that are presently occupied by small postglacial streams: It generally is not more than 25 feet thick, the one principal exception being in the valley of Big Muddy Creek where drilling has revealed 100 feet of clay, interpreted as alluvium, overlying the outwash. Alluvium also veneers many of the larger undrained depressions.

Colluvium.-The base of many of the steeper slopes is mantled by colluvium derived from the wasting of the slopes; the larger areas are shown on the map.

Dune sand.-A considerable area is covered by eolian sand which generally overlies till. Inasmuch as the prevailing wind is from the northwest and the dune areas lie southeast of large outwash bodies, it seems probable that much of the sand was derived from outwash. A sparse growth of vegetation covers much of the sand-dune area. The vegetation is generally ineffective in preventing transport of the sand by strong winds.

The three large dune areas are on surfaces rising from outwash channels. The largest, near Medicine Lake, is southeast of the Dagmar channel and is centered about T. 31 N., R. 57 E. The other two areas together are about equal in size to the largest. They lie southeast of the Big Muddy Creek valley and occupy almost all of the north half of T. 29 N., R. $55 \mathrm{E}$.

Stream-terrace deposits.-In the west half of the area several small tributaries are flanked by evenly bedded terrace deposits of outwash 


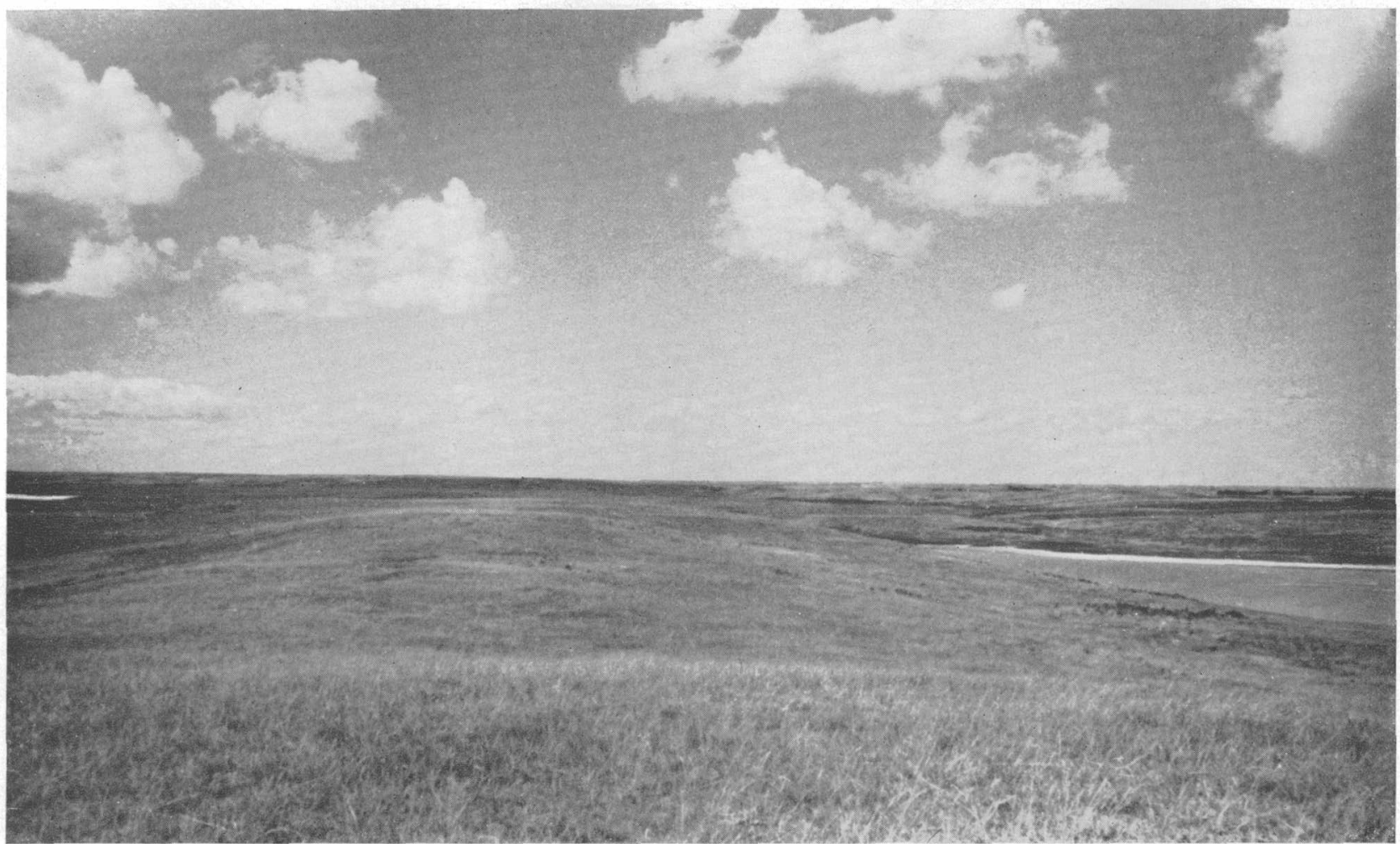




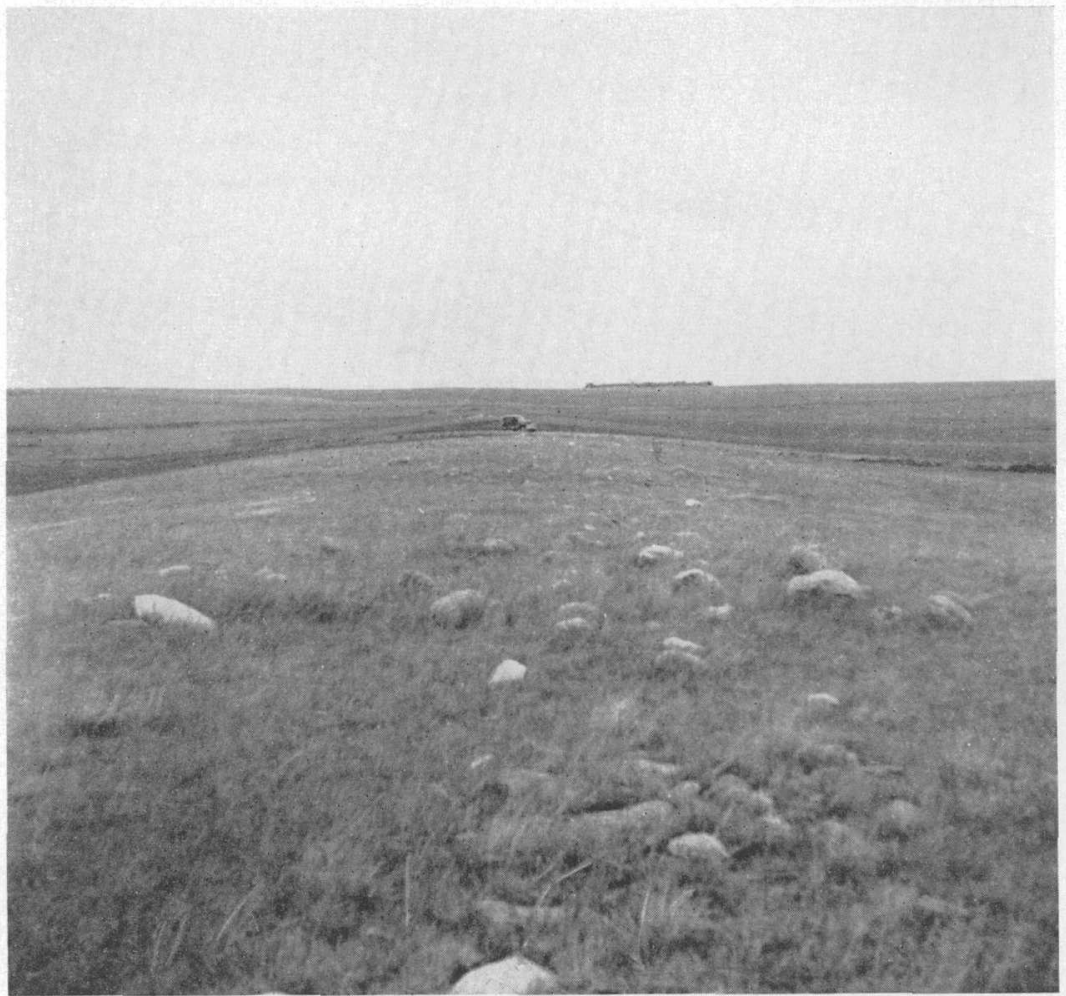

LINEAR TILL RIDGE WITH CONCENTRATION OF GLACIAL BOULDERS ON ITS SURFACE

This ridge may represent some form of crevasse filling, or it may be an annual morainal ridge deposited at the margin of wasting ice. 
sand and gravel mixed with large amounts of locally derived Flaxville gravel. These deposits overlie early Wisconsin (?) till and apparently are younger than some of the outwash deposits. The age tentatively assigned is Recent, perhaps very late Pleistocene.

\section{GEOLOGIC HISTORY}

\section{PRE-PLEISTOCENE}

In northeastern Montana and northwestern North Dakota the transition from sandy beds of the Hell Creek formation of Cretaceous age to lignite-bearing strata of the Fort Union formation of Paleocene age is a relatively inconspicuous one. In general, the warm continental conditions which had prevailed over the plains at the end of the Cretaceous continued into the Paleocene. The regimen of the streams appears to have been unaffected, and sand and silt continued to be deposited. Swamps were formed locally and probably persisted for considerable periods of time before being buried by a new inflow of sand and silt. New swamps; however, were forming to take the place of those destroyed. Each of these former swamps now shows as a lenticular bed of lignite. The restricted extent of the individual lignite beds indicates that the swamps themselves were local rather than regional.

The Paleocene landscape, except for the swamps; was probably a broad, flat plain interrupted by wide, shallow valleys containing generally sluggish streams. A wide variety of botanical specimens have been identified (Leonard, Babcock, and Dove, 1925). Deciduous trees, conifers, and other plants furnished the organic matter of the lignite seams. Invertebrate and vertebrate fossils are relatively rare; turtles and alligators are among the more commonly found forms of the latter.

The beds of the Fort Union formation indicate fluctuating conditions of deposition. At times the streams must have had high velocities, as indicated by crossbedded sandstone; elsewhere, however, quiet conditions of deposition are indicated by widespread claystone.

Near the close of the Tertiary, widespread fluvial gravel, consisting predominantly of well-rounded brown cuartzite pebbles was formed on an erosion surface that beveled the Fort Union formation. This gravel plain is known as the Flaxville Plain or the No. 1 bench (Alden, 1932, p. 12-13). It sloped southeastward and at one time may have covered all of northeastern Montana and reached as far east as the korder of North Dakota. Preglacial drainage probably was controlled by this southeastward-sloping surface, with the exception of the ancestral Missouri River, which may have flowed northeastward across the Smoke Creek-Medicine Lake-Grenora area into Hudson Bay.

By the end of the Pliocene there seems to have been a slight uplift. The consequent streams on the surface of the plain were rejuvenated and began dissecting the gravel and redepositing it at lower levels. 
This dissection resulted eventually in the formation of the broad plain that now forms the general upland of the present area (the No. 2 bench of Alden, 1932, p. 45). The dissection probably reached its maximum at the beginning of the Pleistocene and was terminated by the first ice advance.

\section{PLEISTOCENE}

By early Pleistocene time the Flaxville Plain in Montana and North Dakota had been dissected. In the Smoke Creek-Medicine LakeGrenora area, almost all of the plain had been eroded to form a younger surface, now represented by a northeastward-trending shallow trough (p. 6). Only remnants of the once extensive surface of the Flaxville Plain remained as hills capped by the less easily eroded Flaxville gravel.

Prior to the advance of the first ice sheet over this area, a well-integrated drainage system trending southeastward had been established. Within the stream beds were deposits of sand and gravel derived primarily from the dissection of the Flaxville gravel. Inasmuch as most of these streams were tributary to the ancestral Missouri River, the gravel forming the bed of that river probably also consisted predominantly of Flaxville types such as quartzite, quartz, and chert.

In summary, at the time of the first ice advance Flaxville gravel capped a series of high benches which comprised the remnants of Alden's No. 1 bench. These benches were on a broad, featureless northeastward-trending plain (the No. 2 bench of Alden) that beveled the Fort Union. This plain was slightly dissected by small valleys, most of which were floored with gravel consisting predominantly of reworked Flaxville.

\section{PRE-WISCONSIN (?)}

The first ice sheet that advanced into this area is represented only by the deposits along the east valley wall of Smoke Creek. The preglacial valleys were probably completely mantled by till at this time, and very likely all trace of them was locally obliterated; elsewhere, swales in the topography indicated their outlines. Beneath this till lay the sand and gravel of the valley bottoms. That is probably the origin of the gravel of early Quaternary(?) age under the till(?) along Smoke Creek (fig. $6 ;$ p. 18). The only evidence of the age of these gravels is afforded by this exposure, where the position of the gravels clearly demonstrates their greater age (p. 27).

Radical drainage changes resulted from this first ice advance. Valleys were at first blocked and then buried by the ice, the streams were dammed, and ice-marginal lakes formed. Escaping water from these lakes followed the ice margin and formed broad marginal channels floored with outwash, preglacial directions of flow were reversed, and other broad valleys were cut. Thus, many valleys crossed the area in a random fashion at the time of the wasting of the first ice. 
Many of the major outwash channels, such as the ancestral Big Muddy Creek and Dagmar channels, could have been formed during halts in either the advance or withdrawal of the ice. If formed during a halt in the advance of the ice, they were buried when the advance was resumed and were later used by melt-water streams when the ice withdrew. It is also possible that the outermost channels formed at the glacial limit.

No evidence exists as to the stage of the Pleistocene during which this first ice advanced, its extent, or how it withdrew.

DEPOSITS ALONG SMOKE CREEK

The paucity of till from this ice sheet-only one exposure of till(?) along Smoke Creek-suggests that the next interglacial stage was probably long, if erosion is responsible for the absence of deposits. However, very little drift may have been deposited originally.

Possibly some of the gravels of early Quaternary(?) age were formed during this ice-free period by streams reworking the Flaxville gravel. The newly formed streams were probably quick to dissect the recently deposited till and cut down into the claystone and sandstone of the Fort Union formation. In time, the Flaxville gravel was dissected by headward erosion of the streams, and the valleys were soon floored with gravel similar to the Flaxville. The same streams, however, were simultaneously eroding stratified and unstratified drift. Thus, to the sand and gravel of distinctly Tertiary age was added exotic material from the glacial deposits. Gravel of this type has been mapped as gravels of early Quaternary(?) age.

The age of these older gravels, as defined here, covers a wide range- possibly from late Tertiary to late Pleistocene (p. 16). Some of the deposits may have been formed prior to the advance of any ice across this area, whereas other deposits may have formed during interglacial stages.

\section{ANCESTRAL MISSOURI RIVER}

One of the most obvious changes probably attributable to the advance of the first ice was the diversion of the Missouri River to the east and south of its former course. Despite the considerable amount of geologic work done in this area over the last quarter century, the course of the preglacial Missouri River has still not been definitely established.

Cumulative evidence suggests that the Missouri River during Tertiary time did flow northeastward through this general area, although most of its course has now been destroyed by erosion. If this is true, its valley probably acted as an access route for the advancing ice and was among the first to be dammed.

Calhoun (1906) was among the first to point out that some parts of the Missouri Valley are younger than others, and that these 
younger sections are due to glacial diversions. He referred in particular to the southward diversion of the Missouri River west of the Bearpaw Mountains in north-central Montana.

Bauer (1915) noted the northeastward trend of the topographic sag (Lake Creek channel) that extends for approximately 25 miles from near Poplar to the wide valley of Big Muddy Creek (fig. 16).

This sag and the Dagmar channel, he suggested, might reflect the course of the Missouri River of late Tertiary time. In support of his contention that the preglacial river flowed northeastward, Bauer (1915, p. 54) noted that the Missouri River at the town of Poplar is at an altitude of 1,950 feet, whereas the Assiniboine River in Canada at Brandon, about 260 miles to the northeast, is at an altitude of 1,190 feet.

A northeastward course for the ancestral Missouri River, with subsequent diversion by an early ice sheet, was accepted also by Alden $(1932$, p. 58). Bauer considered the age of the ancestral river to be late Tertiary, but Alden (1932, p. 86) states that "Whether or not it is of pre-Pleistocene age-that is, Tertiary-depends on whether or not the drift is correlated with the earliest stage of glaciation (Nebraskan) or with a much later one." Moreover, Alden suggested that the buried course of the ancestral Missouri River was represented by the narrow string of lakes in northeastern Montana and northwestern North Dakota near the town of Grenora (fig. 16), rather than by the Dagmar channel.

Alden (1932, p. 58) traced his No. 2 bench (the first below the Flaxville Plain) from the headwaters of the Missouri River to the bluffs just west of the town of Poplar (fig. 16); the bench could not be found east of Poplar (Alden, p. 45). He postulated, therefore, that the No. 2 bench marked the preglacial course of the Missouri River, and that the bench once extended northeastward from Poplar. $\mathrm{He}$ attributed its absence in that area today to erosion by Pleistocene melt water $(1932$, p. 86).

Beekly (1912, p. 323), during his study of the coal fields of northeastern Montana, observed the wide northeastward-trending Dagmar channel (fig. 16) filled with sand and gravel. Impressed by the width of the valley and the absence of a stream large enough to cut it, he suggested that this valley might represent either a large preglacial tributary of the Missouri River or the preglacial river itself.

Todd (1914) concluded that the major streams of eastern Montana and western North Dakota had flowed northeastward and discharged into Hudson Bay in preglacial time. The advancing ice blocked their valleys, and the impounded water eventually overflowed the divides and flowed southeastward down the regional slope, around the margin of the ice. In many places the diverted streams became entrenched in courses that were retained after withdrawal of the ice. 


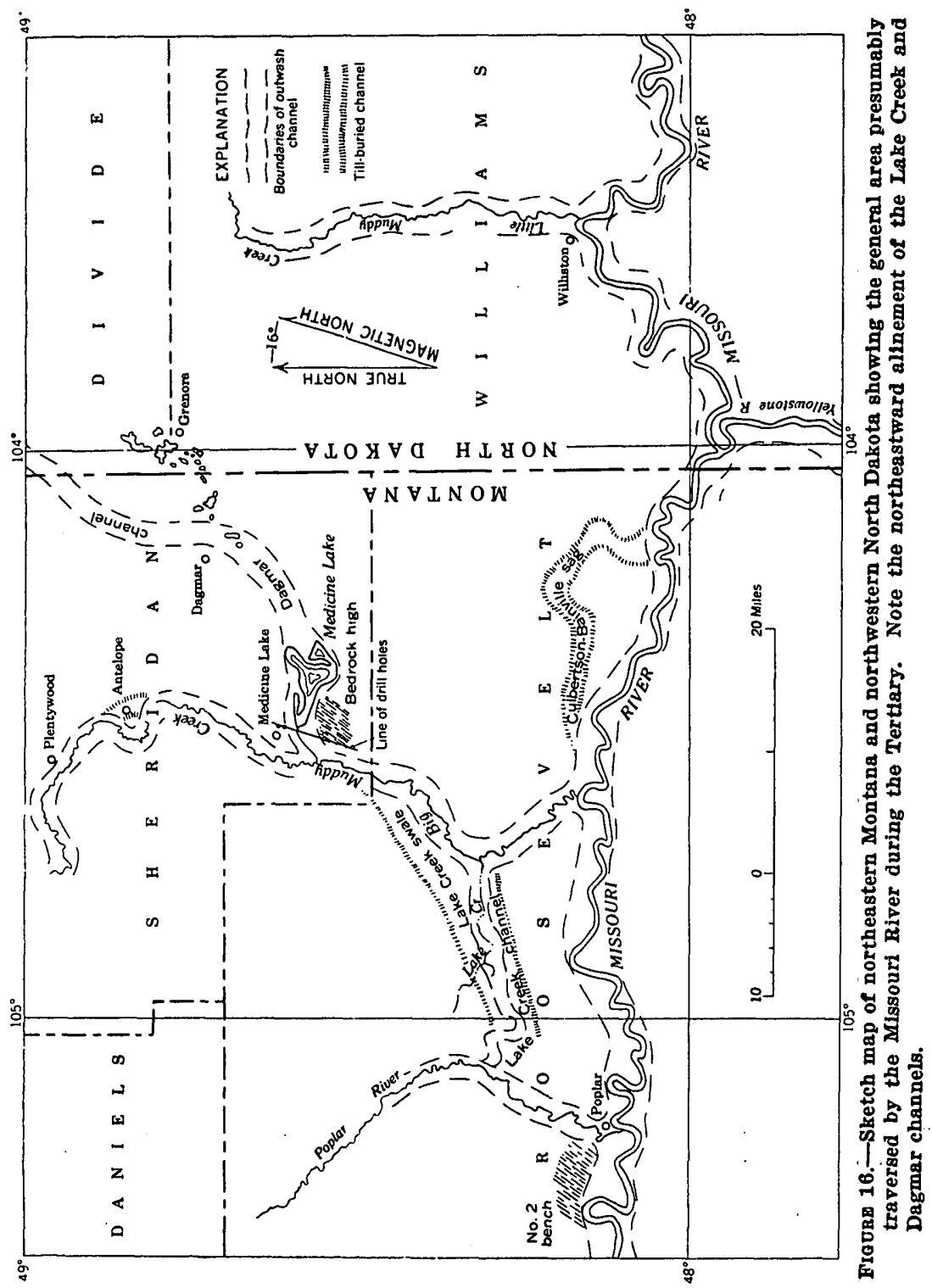


Additional data bearing on the preglacial course of the Missouri River through this area were not found during this survey. However, a deposit of sand and gravel below till was found at an altitude of about 2,080 feet in sec. 13, T. 28 N., R. 50 E., along the walls of a valley tributary to the Poplar River. The valley walls, above the gravel, are composed of till up to the ground surface (altitude 2,200 $\mathrm{ft})$. This gravel may represent deposits on the No. 2 bench and thus mark the course of the preglacial Missouri River suggested by Alden. It is also possible that the gravel was deposited much later than the No. 2 bench.

If Alden's computed gradient of 1.75 feet to the mile is projected northeastward from the bench at Poplar (altitude 2,080 ft), the projection passes over the Lake Creek channel and much of the Dagmar channel and intersects the land surface along an east-west line near Grenora, N. Dak. It seems likely that if the river did flow northeastward its general altitude during the late Tertiary and early Pleistocene was higher than either Beekly or Bauer thought.

\section{FARLY WISCONSIN(?)}

As the early Wisconsin(?) ice advanced from the northeast, it overrode the northwestward-trending bedrock ridge (p. 8) and moved southwestward. As it progressed, the ice spread laterally and encroached upon the adjacent highlands. The actual thickness of the ice is unknown, but an estimate based on the altitudes of the present flood plain and adjacent uplands sets the minimum at about 400 feet. All existing drainageways in this area were blocked by the ice. Lodgment till was thickly plastered on the buried surfaces. Melt and surface water was impounded and presumably formed lakes to the north, probably in southern Saskatchewan, that drained through the Smoke Creek-Medicine Lake-Grenora area. The west limit of this ice is unknown. If the till on the south side of the Missouri River is of the same age as that north of the river, the ice overwhelmed the valley of the Missouri River and extended about 20 miles farther south. There the margin of the till, marked by an ice-marginal channel, trends almost due east. Alden $(1932$, p. 87$)$ thought this till was Iowan or Illinoian in age. Although I have found no direct evidence in support of a specific age for this till sheet, I am inclined to believe that it is early Wisconsin; hence, I am in general accord with Alden.

As the ice wasted it probably retreated spasmodically. Ice lobes were left within the valleys; the impounded streams flowed around these obstructions and rapidly dissected the newly deposited till and the soft underlying Tertiary strata. These new waterways were retained even after the disappearance of the ice from the former stream valleys, which now appear as till-veneered sags; Antelope sag (T. 34 N., R, $55 \mathrm{E}$.) is a part of such a former course. 
Many of the diversion channels in the western part of the area probably formed as the result of the damming of the Smoke Creek and Wolf Creek channels by early Wisconsin(?) ice. Meanwhile, the gradual withdrawal of the ice downslope toward the middle of the Big Muddy Creek valley permitted the melt-water streams to cut successive marginal channels, generally trending southwestward. The ancestral Dagmar channel may have been formed during the withdrawal of this ice.

The valley of the Poplar River was similarly blocked by a wasting mass of ice which lay in the Missouri River valley. The impounded water escaped eastward through a low swale into the Big Muddy Creek channel and then into the Missouri River by a roundabout route. When the Poplar. River valley was clear of ice, the channel to the east was abandoned and the streams resumed their original course.

Probably melt water flowed in all the valleys at some time. Lacustrine silt at the heads of several streams tributary to the Missouri River is further evidence that this river may have been dammed in a similar fashion.

The esker and kames within the western part of the area were also formed during the melting of early Wisconsin(?) ice. Melt water heavily loaded with outwash aggraded the channel floors, and parts of the ice-contact features were buried by the outwash (sec. 20, T. 30 N., R. 52 E.). This outwash cannot be differentiated with any assurance from that deposited at a later stage by melting of the Mankato ice. Thus, in many localities, the Mankato outwash probably overlies early Wisconsin (?) outwash.

\section{MIDDLE WISCONSIN(?)}

Nothing is known about the second interglacial stage and the middle Wisconsin(?) in this area. Howard (1950) has described drift, possibly of middle Wisconsin(?) age, to the east, but the direction of movement of the ice, its limits, or the extent of its deposits in that area have not yet been determined.

\section{LATE WISCONSIN (MANKATO SUBSTAGE)}

Nothing is known about the duration or climatic change of the middle Wisconsin(?) to Mankato interval in the Smoke CreekMedicine Lake-Grenora area.

The Mankato ice crossed the northwestward-trending bedrock ridge (now mantled by the Max moraine) north of the Smoke CreekMedicine Lake-Grenora area and extended as a lobe southwestward down the ancestral Dagmar channel. It advanced as far as Medicine Lake and spread laterally to the Coalridge channel on the north and to the Cottonwood Creek channel on the south (pl.4). A comparison 
of the altitudes of the plain of the Dagmar channel and the adjacent uplands suggests a minimum thickness of about 150 feet for this ice.

Numerous ice-contact deposits were formed during the wasting of the Mankato ice; the kames and eskers within sec. 29, T. 32 N., R. $56 \mathrm{E}$., are typical. Continued wasting and withdrawal of the Mankato ice resulted in the formation of kame-terrace deposits adjacent to remnant ice blocks, as well as deposition of large bodies of sand and gravel in the ice-free channels. Locally the melt-water streams may have eroded some of the early Wisconsin(?) outwash, but, in general, aggradation predominated. Thus, it seems likely that Mankato outwash mantled whatever early Wisconsin(?) outwash was deposited previously. The prevailing northwesterly winds probably started to form most of the sand dunes in this area shortly after deposition of the outwash.

A small segment of the east half of the Smoke Creek-Medicine LakeGrenora area is crossed by the northwestward-trending Max moraine (Townsend and Jenke, 1951). Till forms the surface of the high, and the broad crest is marked by numerous undrained depressions and till knobs. Perched lakes are common along the crest and flanks, as are ice-contact deposits and erratics as much as 15 feet in diameter. As one approaches the high from the flat plain which lies northeast of it, the rapid change from the smooth topographic features common to ground moraine to the irregular, hummocky topography characteristic of terminal and recessional moraines is very obvious. The contrast in topography is not as marked, however, southwest of the high where the change is gradational and difficult to discern.

The topographic high was sufficient to impede the southward movement of the continental glaciers. In some places the ice passed through the high in previously formed valleys; elsewhere, the ice overrode the high. If the preglacial Missouri River did trend northeastward, its valley may have served as an access route.

It is not known how many times the last ice overrode the high; the ice most likely continued to push debris against the prominence in successive attempts to override it, until the broad 20- to 25-mile-wide crest was formed. Thus, in time, the high was surfaced with varying thicknesses of till.

The Mankato ice which surmounted or bypassed the obstacle moved as far southwest as Medicine Lake. However, the limited extent of till and ice-contact features attributable to the ice south of the high suggests that much of the glacier was confined north of the high.

\section{RECENT}

Probably alluvium was deposited on the major valley floors even before the complete disappearance of the ice, and the tributary drainage that was graded to these larger streams followed suit. In places, 
therefore, a layer of alluvium of varying thickness has been deposited on the outwash. At present, small tributary streams, incongruous in size when compared to the broad valleys they occupy, meander from one side of the valley to the other doing little more than reworking the finer components of the alluvial material.

The uplands have been only slightly dissected since deglaciation; most of the kettles and undrained depressions appear unmodified, and ice-contact surfaces are undisturbed. In several localities the till has been trenched, exposing the underlying strata, perhaps in part by melt-water streams while ice was still in the area.

\section{MINERAL RESOURCES}

Mineral resources in the area include lignite, sodium sulfate (glauber salt), and construction materials, of which sand and gravel are most abundant. As yet there have been no tests for oil and gas in the Smoke Creek-Medicine Lake-Grenora area.

COAL

The coal beds in the Montana sector of the Smoke Creek-Medicine Lake-Grenora area have been described previously: those west of Big Muddy Creek by Smith (1910), those east of Big Muddy Creek by Beekly (1912). Bauer (1912) has discussed the coal beds south of Plentywood, Mont., and those in the North Dakota sector have been described by Leonard, Babcock, and Dove (1925). In view of these reports, descriptions of coal beds are omitted from this report.

\section{SODIUM SULFATE}

Sizable deposits of sodium sulfate are found in undrained depressions in the east half of the Smoke Creek-Medicine Lake-Grenora area. The salt, known commercially as glauber salt, is present in two forms - the decahydrate, mirabilite $\left(\mathrm{Na}_{2} \mathrm{SO}_{4} \cdot 10 \mathrm{H}_{2} \mathrm{O}\right)$, and an anhydrous form, thenardite $\left(\mathrm{Na}_{2} \mathrm{SO}_{4}\right)$. Its principal use is in the manufacture of kraft paper, although it is also used in the glass, paint and varnish, textile, and tanning industries.

Large deposits are mined in Wyoming, Utah, and Idaho. The large deposits in southern Saskatchewan presumably are extensions across the international border of the deposits herein described.

Considerable quantities of the salts are present in this area. Statements as to tonnage, however, are misleading unless it is known whether the computations are based on the hydrous or anhydrous form. Calculations of the hydrous forms will yield tonnage figures more than twice those of the anhydrous varieties. All data cited by Binyon (1951) are of anhydrous sodium sulfate.

Conservative calculations of the estimated reserves of anhydrous sodium sulfate in all examined deposits in North Dakota amount to 
more than 30,439,000 short tons (Binyon, 1951, p. 35). Of this, Binyon states that $23,849,000$ tons is in permanent beds, 421,000 tons is in saline brines, 2,450,500 tons is in the form of intermittent beds, and the remaining $3,718,500$ tons is in crusts and muds.

All the commercially important deposits of sodium sulfate in this area consist of a thick bed of the salts overlain by saline brine within an undrained depression. In general, as the brine is concentrated by evaporation during the dry season, crystals of sodium sulfate form and sink to the lake bottom to form a thin layer known as the intermittent bed. This thin layer dissolves if the temperature of the brine rises or if there are periods of heavy precipitation. However, with continued deposition the crystals compact and form a solid bed, the permanent bed, which eventually may be as much as 80 feet thick (Lavine and Feinstein, 1936, p.4).

All the water in the basins may be evaporated during periods of unusual drought, leaving a fine white powdery residue that is predominantly sodium sulfate. Much of this is subsequently dispersed over the surrounding countryside by the wind.

Chemical analyses of several deposits in the area indicate that sodium sulfate constitutes more than 90 percent of the soluble material.

Chemical analyses of glauber salt

[After Lavine and Felnstein (1936, p. 5)]

$\mathrm{NaCl}$

$\mathrm{Al}_{2} \mathrm{O}_{3}$

$\mathrm{Fe}_{2} \mathrm{O}_{3}$

$\mathrm{Na}_{2} \mathrm{CO}_{3}$

$\mathrm{NaHCO}_{3}$

$\mathrm{CaSO}_{4}$

$\mathrm{MgSO}$

$\mathrm{Na}_{2} \mathrm{SO}_{4}$

1 A verage of 61 samples.

2 A verage of 128 samples.

\begin{tabular}{|c|c|}
\hline $\begin{array}{l}\text { Grenora } \\
\text { Lake } 1\end{array}$ & $\begin{array}{l}\text { Grenora } \\
\text { Lake 2 }\end{array}$ \\
\hline 1. 73 & 1. 30 \\
\hline $0^{3}$ & \\
\hline & tr \\
\hline $\begin{array}{l}1.58 \\
1.31\end{array}$ & $\begin{array}{l}\text { 1. } 63 \\
\text { 2. } 06\end{array}$ \\
\hline 94.84 & 94.28 \\
\hline
\end{tabular}

\section{LOCATION OF DEPOSITS}

The sodium sulfate deposits are restricted to the eastern part of the area (pl. 1), in western North Dakota and northeastern Montana. Many of the lakes in North Dakota and Montana are saline. However, this salinity alone does not necessarily indicate the presence of a deposit, for in places there is no valuable permanent bed of sodium sulfate. Where the water is highly saline, however, experience shows that deposits are likely to be present. Until adequate work has been done to determine which lakes are underlain by permanent beds, only conjectural statements regarding the economic worth of unproved saline lakes can be made.

In North Dakota there are four proved sodium sulfate deposits: Grenora Lake 1, Grenora Lake 2, Stink Lake, and Stady E Lake (pl. 1). Grenora Lake 1 and Grenora Lake 2, about 3 miles west and 
northwest respectively of Grenora (sec. 12, T. 159 N., R. 103 W.), were thoroughly investigated as a project of the Federal Emergency Relief Administration (FERA) that was completed at the end of 1935 (Lavine, no date). Stink Lake, which occupies the eastern part of sec. 5, T. 159 N., R. 103 W., and Stady E Lake, secs. 5 and 8, T. 160 N., R. 99 W., were examined in the course of a U. S. Bureau of Mines study of sodium sulfate deposits in North Dakota and eastern Sheridan County, Mont. (Binyon, 1951). Both the FERA study and that of the Bureau of Mines have added materially to knowledge about the deposits.

Only one proved sodium sulfate deposit, the Brush Lake saline slough which occupies the western part of section 26 and the eastern part of sec. 27, T. 33 N., R. 58 E., is known in the eastern part of Sheridan County, Mont. The other lakes discussed are within the category of possibly economically important deposits.

NORTHWESTERN NORTH DAROTA

GRENORA LAKE 1

Grenora Lake 1, in the southwest corner of Divide County, covers parts of secs. 10, 15, 16, and 21, T. 160 N., R. 103 W. It is easily accessible by graded roads, some of which are graveled. These roads lead to the railhead at Grenora. Not all the roads are all-weather, but they could easily be made so.

The lake is about 1 mile wide and $11 / 2$ miles long. Steep banks surround it, except on the south. Along the shores and in the lake are small seeps and springs; during periods of drought all except a few of the larger springs cease flowing. The spring water is charged with salines, and analyses show an average content of about 175,000 ppm of sodium sulfate (Lavine and Feinstein, 1936, table 3).

The permanent bed, which is very hard, begins about 1 foot below the surface and is about 30 feet thick. The deposit covers an area of about 500 acres and, according to Lavine and Feinstein, contains about $1,750,000$ short tons of impure glauber salt. Binyon (1951, table 3) has revised this to 980,000 tons on the basis of recent calculations.

GRENORA LAKE 2

Southwest of Grenora Lake 1 is Grenora Lake 2, a large undrained depression in secs. $28,29,32,33$, T. 160 N., R. 103 W., that also contains a proved sodium sulfate deposit of considerable size. Most of the deposit is at the south end, about 1 mile north of the main all-weather road leading to the railhead at Grenora. From this gravel-surfaced road a dirt track leads to the south edge of the lake. The banks are very steep at this end and the lake is not easily accessible. A sectionline road passes near the westernmost extension of the lake, where the banks slope gently, but at this point the deposit is very shallow and limited. In general the banks are steep on three sides of the lake. 
The deposit is much larger than that of Grenora Lake 1. Although it covers a similar area (500 acres), it is thicker over most of its extent. The major part of the deposit covers practically all of the section, and the margins extend into adjacent sections. Springs occur both around the edges of the lake and in its middle. Chemical analyses of water derived from these springs indicate a high brine concentration.

This deposit is reported by the Bureau of Mines to contain 5,500,000 short tons of impure glauber salt (Binyon, 1951, table 3). An isopach map (Lavine and Feinstein, 1936, p. 5) of this bed indicates a northward elongation of the thickest part of the deposit (fig. 17).

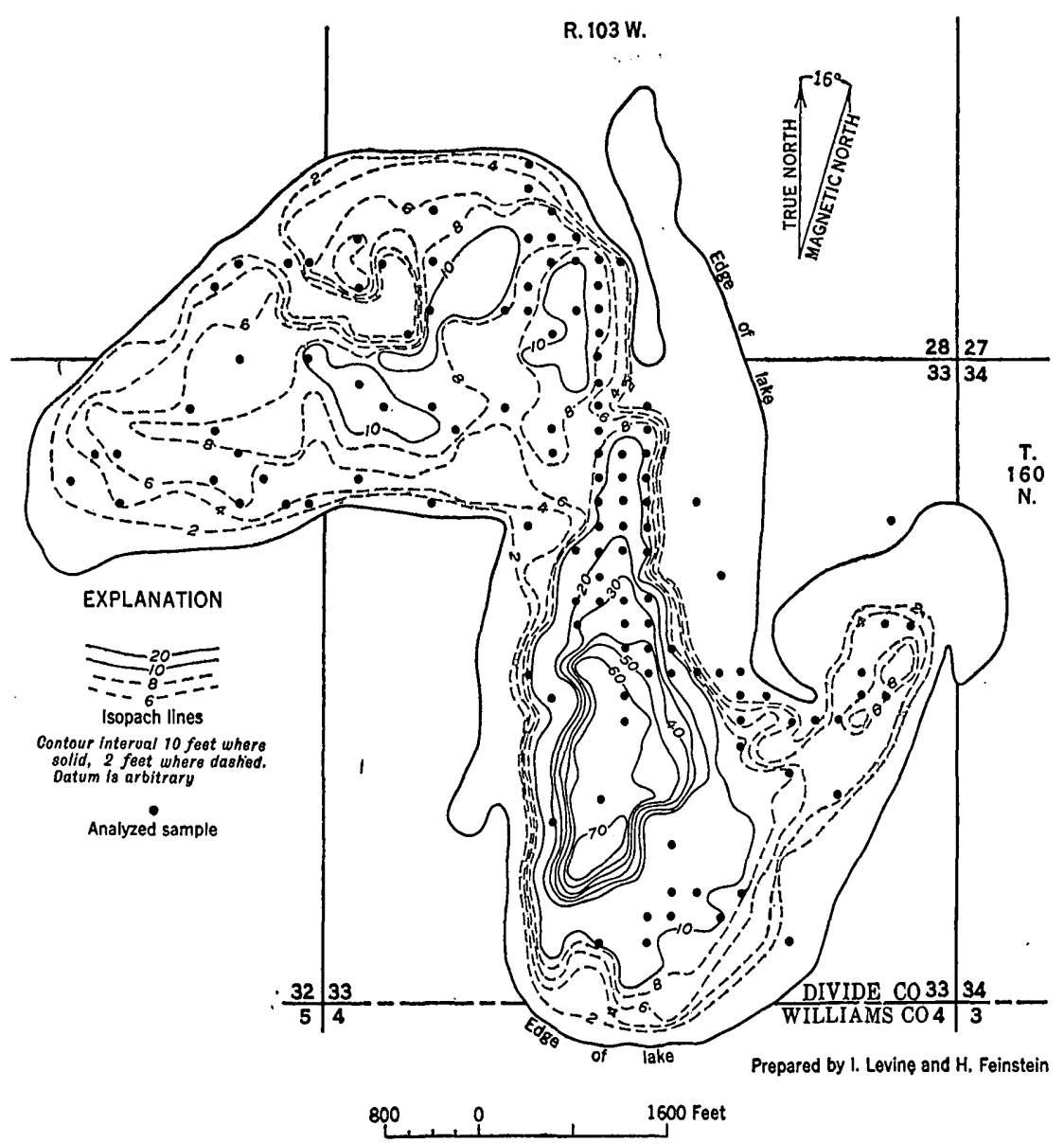

Eradra 17.-Isopach map of the sodium sulfate deposit underlying Grenora Lake 2.

STINK LAKE

Stink Lake, adjacent to the main county road leading to Grenora, is in the eastern part of sec. 5, T. 159 N., R. 103 W., and covers an area of about 87 acres. It is 1 mile southwest of Grenora Lake 2. The lake is named for its unpleasant odors. 
Stink Lake was tested by the Bureau of Mines during the winter of 1950 and was found to contain a permanent bed of sodium sulfate about 8 feet thick (Binyon, 1951, p. 23). Binyon estimates that the deposit contains about 1,233,000 short tons of impure glauber salt.

BTADY E LAKE

An irregularly shaped lake that overlies a sizeable deposit of glauber salt is astride the section line between secs. 5 and 8, T. 160 N., R. 99.W. The lake has no local name and Binyon $(1951$, p. 6) refers to it as Stady E. Stady E covers an area of about 132 acres and is easily accessible from the west by a graded and graveled section-line road. The lake is about 13 miles distant from a railroad depot at Appam, N. Dak. (pl. 1). The water of the lake is highly saline, and drilling by the Bureau of Mines (Binyon, 1951, table 3) has indicated about 1,846,700 tons of impure sodium sulfate.

TWIN IAKEB

Other lakes show varying percentages of salines in their waters; Twin Lakes and several small adjacent lakes are of this type. They are mentioned here but are not considered to warrant extensive investigation. In many the percentage of sodium sulfate is so slight as to imply the absence of a permanent bed. Binyon (1951, p. 33) indicates that the depth of brine and the thickness of the intermittent crystals in the Twin Lakes "are too small to warrant consideration."

OTHER SMALI LAKES

Minor sloughs that may contain small deposits of sodium sulfate are oriented apparently at random throughout the area. Typical are the two small lakes in sec. 8, T. 159 N., R. 103 W.; the north lake covers an area of about 8 acres and the south one about 17 acres. The water of both lakes is highly saline, suggesting the presence of a permanent bed of sodium sulfate.

Another possible commercial deposit occupies the east half of a large depression that straddles the Montana-North Dakota line. The major part of the slough is in North Dakota in sec. 19, T. 160 N., R. $103 \mathrm{~W}$. The water is moderately saline, and the lake may or may not be underlain by a sodium sulfate deposit. The lake covers an area of about 75 acres.

\section{NORTHEASTERN MONTANA}

Only the Brush Lake saline slough has been proved in the Montana sector of the Smoke Creek-Medicine Lake-Grenora area. However, additional deposits farther to the north, beyond the limits of this area, underlie several of the lakes (Westby $\mathrm{A}, \mathrm{B}$, and $\mathrm{C}$ ) near the town of Westby, Mont., in sec. 13, T. 36 N., R. 58 E. (Binyon, 1951).

$460517-59-6$ 
BRUSH LAKE SALINE SLOUGH

A large undrained depression south of fresh-water Brush Lake is referred to as the Brush Lake saline slough. The major part of the slough (pl. 9) occupies the western part of sec. 26 and the eastern part of sec. 27 , T. 33 N., R. 58 E., an area of about 350 acres.

The nearest railhead is at Grenora, N. Dak., about 9 miles to the east. A good all-weather road, however, leads northward from the north edge of the slough to an intersection with a similar road into Grenora.

The banks of this slough slope gently, permitting easy access to the slough. Seeps are present around the edges of the slough and probably in its center. The water evaporates and leaves a deposit of fine white powdery sodium sulfate during periods of excessive drought. This powder is scattered by westerly winds; the veneer of powder has been observed as far as 2 miles from the lake.

Tests by the Bureau of Mines indicate that the Brush Lake saline slough is underlain by a permanent bed of sodium sulfate that is between 6 and 7 feet thick (Binyon, 1951, p. 24). Binyon (1951, p. 50) estimates that the reserves of impure glauber salt approximate $2,824,000$ tons.

HORSESHOE LAKE

This peculiarly shaped lake is about $11 / 2$ miles southwest of Stink Lake and is easily accessible by graded road. The main county road leading to Grenora is about $11 / 2$ miles north of the west edge of the lake. The lake covers an area of about 150 acres largely within the eastern part of sec. 18, T. 159 N., R. 103 W., but with its westernmost tip straddling the Montana-North Dakota State line.

The slopes along the shores of the lake are gentle, and the lake can be approached from any side. Its water is saline, suggesting that this lake may overlie a valuable salt deposit. Tests by the Bureau of Mines during the winter of 1950 disclosed, however, that the lake "contained only 0.34 feet of brine and 0.29 feet of salts . . ." (Binyon, 1951, p. 33). These unfavorable results suggest that a permanent bed does not underlie Horseshoe Lake; however, only three holes were drilled and more favorable results might be forthcoming with additional exploration.

SLOUGH IN SEC. 6 , T. 32 N., R. 59 E.

A second deposit (pl. 10) possibly worthy of investigation in the Montana sector of the Smoke Creek-Medicine Lake-Grenora area is an area of about 70 acres that straddles the township line between sec. 1 , T. 32 N., R. 58 E., and sec. 6, T. 32 N., R. 59 E. The sides of the slough are gentle, and the edges of the deposit can be approached 
by car. Graded dirt roads pass south and east of the lake; the best approach is on the south. It is about 13 miles southeast of the nearest railhead, at Grenora, N. Dak.

The lake is in a large, deep, undrained depression whose bottom is at least 55 feet below the surrounding upland. It is intermittent, and during periods of dry weather the evaporating water deposits crystalline sodium sulfate on the flat.

SLOUGH WEST OF HORSESHOE LAKE

About one-quarter mile southwest of Horseshoe Lake is a slough that may contain a deposit of sodium sulfate. It occupies the southeast corner of sec. 24, T. 33 N., R. 58 E., and covers an area of about 60 acres. The same county-line road that leads to Horseshoe Lake approaches this lake as well. Because of the marshy condition of the area, the most accessible approach is at the east end. The banks of the lake are gently sloping, and the bottom of the lake is only about 15 feet below the surrounding upland. The water is saline, and the edge of the depression is encrusted with crystals of the salt.

\section{SLOUGE - IN SEC. 2 , T. 33 N., B. 58 E.}

An undrained depression in the east-central half of sec. 2, T. $33 \mathrm{~N}$, R. $58 \mathrm{E}$., contains a lake that covers about 40 acres. The lake is easily approached at its east end by a well-graded county-line road. The road is not all-weather, however.

The water of the lake is only slightly saline; therefore it is unlikely that the lake is underlain by a permanent sodium sulfate deposit. Tests of the surrounding marshy area support this conclusion (Sahinen, 1948).

SLOUGH IN SEC. 2, T. 34 N., R. 58 E.

The undrained marshy depression in sec. 2, T. 34 N., R. 58 E., and several smaller sloughs to the west, should probably be included with deposits of doubtful value. Although the water in the lakes is slightly saline, the presence of fresh-water marshes along their flanks implies that a permanent bed of sodium sulfate is probably absent. The longest lake is in the western part of sec. $2, T$. 34 N., R. 58 E., and covers an area of about 166 acres. It is surrounded by gentle slopes and is easily accessible by a county-line road along its west flank. None of the roads in the immediate vicinity are all-weather.: The nearest railroad depot is Westby, Mont. (sec. 13, T. 36 N., R. 58 E.), about 10 miles to the northeast.

Smaller lakes whose water is also slightly saline are in the northern part of sec. 10, T. 34 N., R. 58 E. These, too, are probably not underlain by permanent beds of sodium sulfate. 


\section{LOCALIZATION OF DEPOSITS}

Many of the salt deposits in Montana, North Dakota, and Saskatchewan are definitely alined. This is shown more clearly in southern Saskatchewan (fig. 18) than within this part of Montana and North Dakota. Nevertheless, a certain orientation of the American deposits to the northeast is apparent. This has been noted by both American and Canadian geologists, and various hypotheses have been presented in explanation.

No attempt is made here to explain the chemical mode of origin of the sodium sulfate deposits within the Smoke Creek-Medicine LakeGrenora area. The sodium sulfate may be derived from the glacial drift mantling the area, from the underlying Fort Union formation, or, most likely, from both. Till alone does not seem to be the principal source of the salines, as many lakes within till-floored basins are free of them.

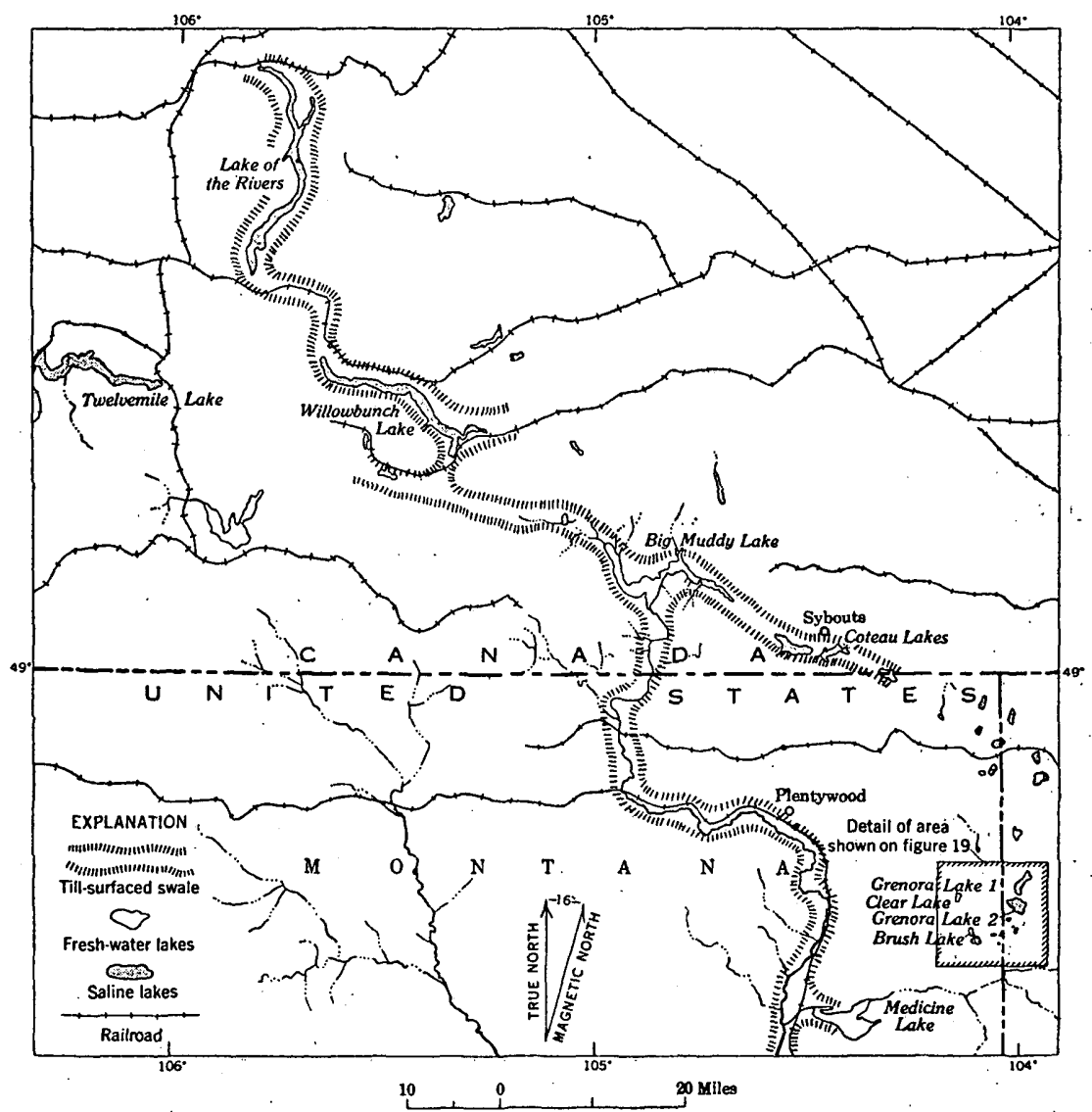

Figore 18.- Sketch map of southern Saskatchewan, northeastern Montana, and northwestern North Dakota showing relation of saline lakes to glacial channels. 


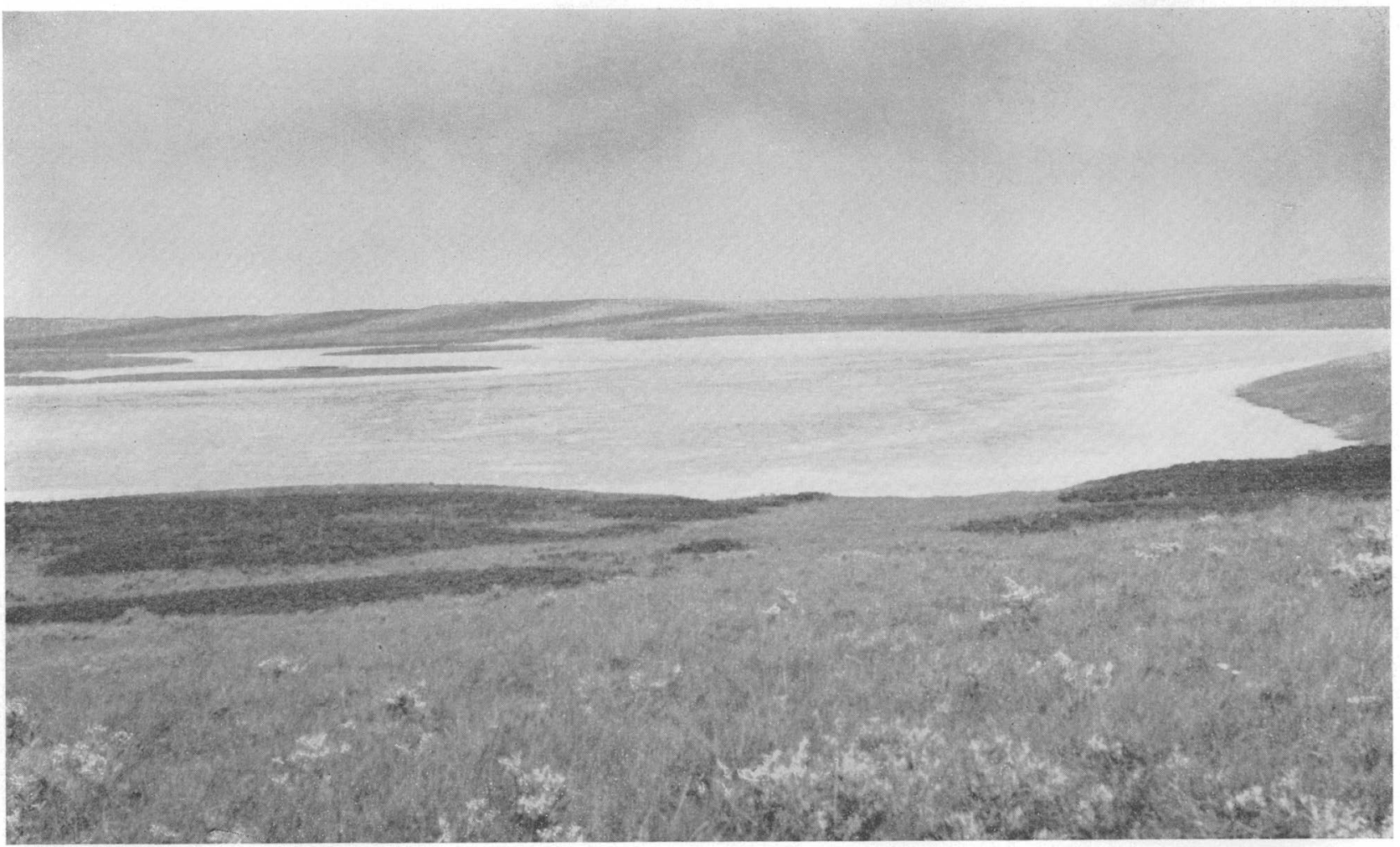

SALT ENCRUSTATION ALONG SHORES OF SALINE SLOUGH

The salt suggests the presence of an underlying permanent bed of sodium sulfate (Montana, sec. 26, T. 33 N., R. 58 E.). 


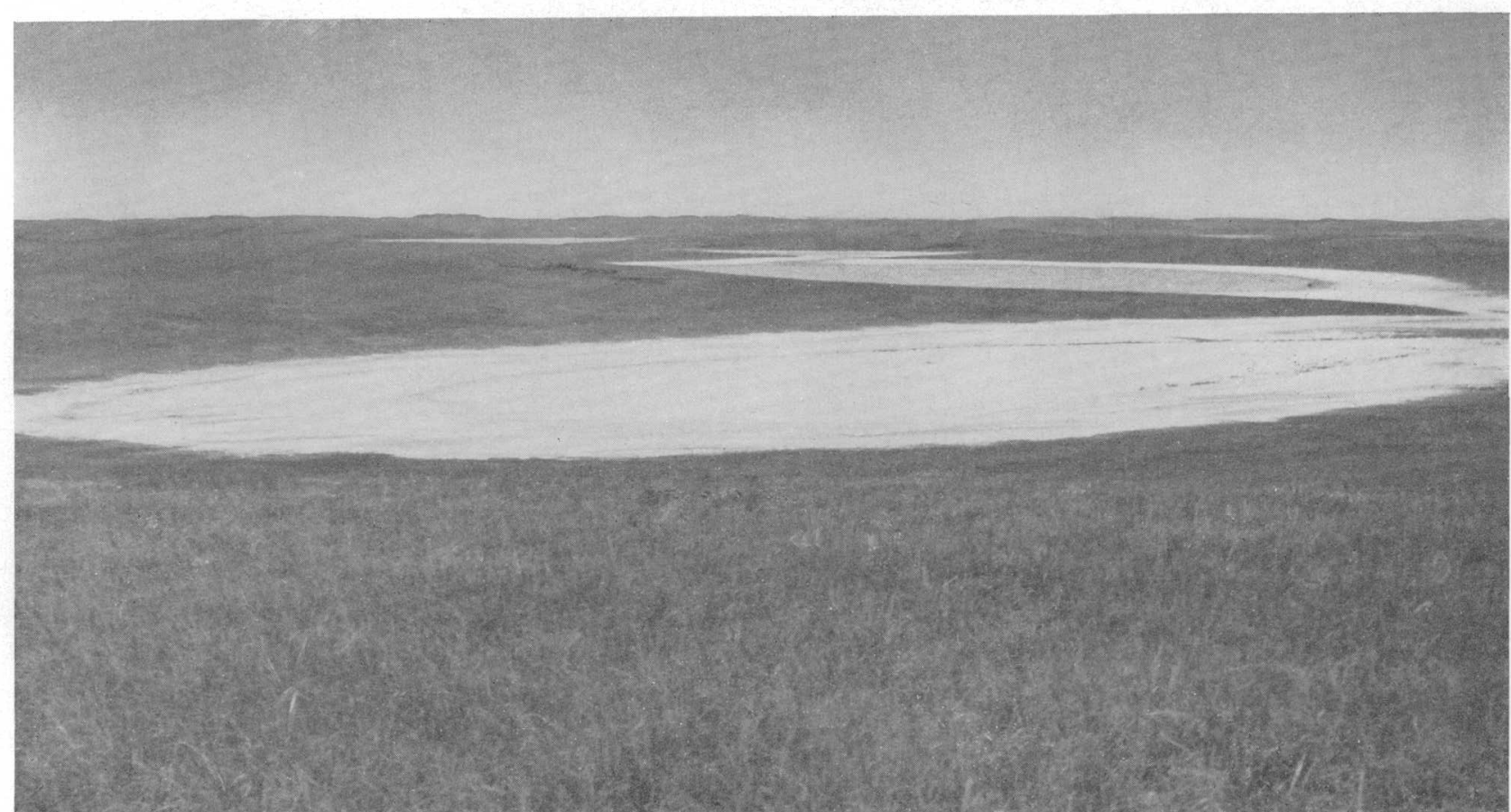

SMALL SALINE SLOUGH

This slough may be underlain by a permanent bed of sodium sulfate. 
The sodium sulfate deposits in this area are but a southward extension of similar deposits in Saskatchewan, as indicated by geologic features in both sets of deposits that can be traced across the international boundary. It seems reasonable to expect, therefore, that a hypothesis which satisfactorily explains one set of deposits might be applicable to the other. It is hoped that the hypothesis herein presented may furnish criteria of value in exploration for additional deposits of sodium sulfate.

\section{FIELD RELATIONS}

In general, the sodium sulfate deposits are within undrained depressions, the walls and floors of which commonly consist of till. Within this sector of northeastern Montana and northwestern North Dakota, later deposition has locally mantled the till with a relatively thin veneer of sand and gravel.

Almost all the deposits are circled by springs whose water is normally charged with salines, and there are also springs within the deposits.

Many of the lakes overlying valuable sodium sulfate deposits are elongate, narrow, and sinuous. This is more apparent in Canada than within the United States (fig. 18). These deposits form a broad belt about 30 miles wide that trends northwestward through North Dakota, Montana, and Saskatchewan. However, local variations occur within this belt. For example, Grenora Lake 1 and Grenora Lake 2 are elongated northeastward (fig. 19). In Canada, however, the larger deposits trend northwestward (fig. 18). Willowbunch Lake is saline as is Lake of the Rivers farther to the northwest; Big Muddy Lake, to the southeast, apparently is a fresh-water lake, although the Coteau Lakes (Sybout Lakes) directly southeast of it are saline. (See Cole, 1926, map.)

Adjacent to many saline sloughs are fresh-water lakes. Within the Smoke Creek-Medicine Lake-Grenora area excellent examples are available. Adjacent to the Brush Lake saline slough, which occupies parts of secs. 26 and 27 , T. 33 N., R. 58 E. (fig. 19), is fresh-water Brush Lake. Despite the proximity of the lakes, their water levels are not accordant. The altitude of the water level of Brush Lake is about 1,956 feet, whereas that in the slough constantly changes but in general is 4 to 6 feet lower. Similar discordancies are found elsewhere in the area. It seems apparent, therefore, that in certain localities at least, contiguous fresh-water and saline lakes have no subsurface connection.

OLDER HYPOTHESES OF LOCALIZATION

Various hypotheses have been advanced for the localization of the sodium sulfate deposits. Alpha (no date) suggested that the northeastward courses of the preglacial Missouri and Yellowstone Rivers 


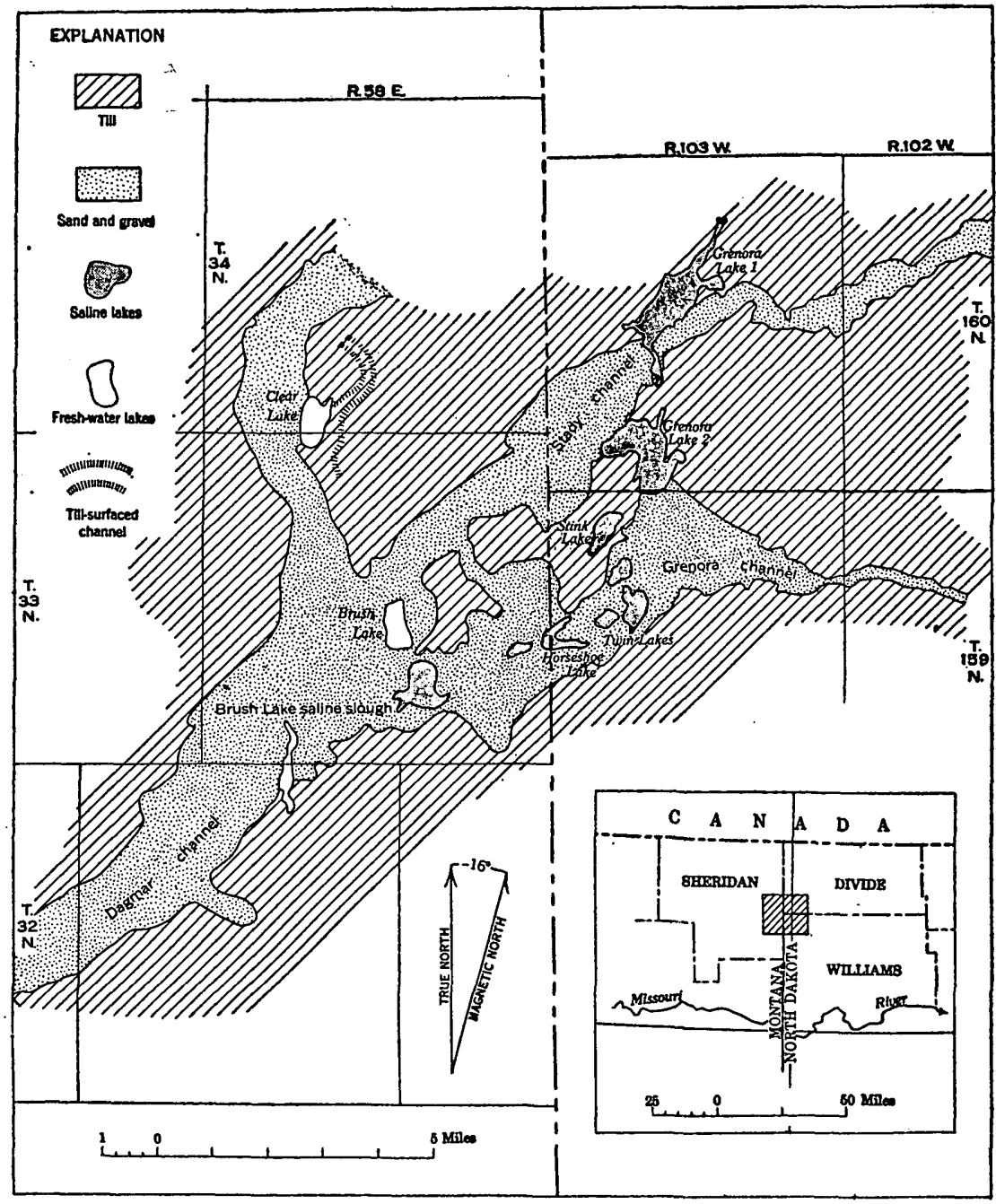

Figurb 19.-Geologic setting of the sodium sulfate deposits in the Grenora and Stady channels. The saline lakes may overlie permanent beds of sodfum sulfate.

may have influenced the orientation of the deposits. This seemed plausible for the area of his investigation because the major saline deposits were alined along Alden's proposed course of the ancestral Missouri River (Alden, 1932, p. 21) across northeastern Montana and northwestern North Dakota. However, Alpha offered no explanation of the Canadian deposits in Saskatchewan that lie beyond the lateral limits of the ancestral Missouri River.

Geologists of the Saskatchewan Department of Natural Resources and Industrial Development (1947, p. 57), referring to the origin of the Saskatchewan sodium sulfate deposits, thought that their alinement 
might be attributed to recessional valleys cut during the retreat of the last ice. These valleys were used first as drainageways, and with diminution of precipitation they became interior-drainage basins. Mineral salts were then carried by runoff into the lakes within these basins. In time the salts were concentrated by evaporation, and sodium sulfate was precipitated on the basin floor.

The recessional valleys described are floored with bedded deposits of sand and gravel. Within the Smoke Creek-Medicine Lake-Grenora area, fresh-water lakes are found in these valleys; Brush Lake within the Dagmar channel (fig. 19) is an example. Most of the valleys in which the saline deposits are found, however, are layered with till. Moreover, drilling in many of the saline lakes has shown a layer of till immediately below the permanent bed of sodium sulfate.

\section{HYPOTHESIS OF PRESENT WORK}

It is suggested that the sodium sulfate deposits in this region are localized along channels that formed marginal to an ice front. The ice-marginal channels were floored with sand and gravel before the renewal of the advance of the ice and subsequently were partly buried by till (p. 21). Deposits formed within the confines of such channels would naturally be alined (fig. 7).

It should be recognized that two types of channels are present within this area. One type was formed during the withdrawal of the last ice and is floored with sand and gravel. Its surface is till free. The other type of channel is buried beneath till of a subsequent ice advance and is reflected on the surface as a shallow till-surfaced swale marked by local depressions. The exploitable deposits of sodium sulfate are within the depressions in these till-surfaced channels.

Thus, crisscrossing the area and showing little or no relation to the regional slope of the land are till-surfaced channels and till-free channels, which are floored with glaciofluvial sediments. In some localities the till-surfaced channels may intersect the till-free outwash channels at shallow depths.

Local undrained depressions pit the floors of the till-surfaced channels, and it is within these depressions that the saline lakes have formed. The alinement of many of the lakes is thus a reflection of a buried valley. Many of the saline lakes, however, have an irregular outline.

I believe that the valuable deposits of sodium sulfate are found in such basins within these shallow swales. Most of the water in the brine lakes is probably attributable to the many springs in and around the lakes. Ground water under hydrostatic head, percolating in the till-buried sand and gravel channels, breaks through to the surface in the depressions where the till is thin. Once within a basin the water 
is unable to escape through the impermeable till slopes and floor. Constant addition of salt by the springs, together with evaporation of the enclosed water, soon results in the formation of a sodium sulfate brine. In time, an intermittent layer of sodium sulfate is deposited. Gradual accumulation over a period of years forms a permanent bed of sodium sulfate which is penetrated only by the various springs originally responsible for the deposit.

Lakes such as Clear and Medicine Lakes, within the till-free type of channel, would have a free circulation of ground water with subsequent subsurface escape of the salines. It is this continual circulation that removes the salines and prevents their being concentrated in one locality.

In several localities, fresh-water lakes lie within a few hundred feet of saline lakes. Grossman $(1949$, p. 60) has attempted to explain this proximity of the two different types of lakes by a hypothesis of basin integration. He suggests that many of the saline lakes are connected with the adjacent fresh-water lakes by a low swale. Grossman cites several examples of saline lakes that are 4 to 6 feet lower than nearby fresh-water lakes. Thus, during cycles of excessive rainfall, the rise in water level results in the decantation of the salts from the higher lakes to the lower lakes. The final result, according to Grossman, would be the juxtaposition of a fresh-water lake and a saline lake. Insufficient data are available to test this hypothesis. However, such decantation if it did occur is essentially an explanation for the phenomenon of a fresh-water lake adjacent to a saline lake. It does not affect the basic premises of my hypothesis for the localization of the deposits.

I believe that an explanation for the proximity of fresh-water lakes to saline lakes probably lies in the two types of channels present in this area. Where both types of channels are present, but fail to intersect, the anomalous situation of contiguous fresh water and saline lakes results. Such a relationship probably exists between Brush Lake and the saline slough immediately south of it. Most likely Brush Lake is influenced by the subsurface drainage of the Dagmar channel. The slough, however, probably marks a buried channel, as indicated to the northeast by the presence of Horsehoe Lake, Twin Lakes, Stink Lake, and Grenora Lake 1 and Grenora Lake 2 (fig. 19).

This hypothesis for the localization of sodium sulfate deposits is described in greater detail elsewhere (Witkind, 1952).

\section{CONSTRUCTION MATERIALS}

A brief resume of the more important engineering characteristics of the major lithologic units in the area is in the pocket at the end of this report (chart 1). More detailed information about the glacial units is included in the discussion of till and glaciofluvial deposits. 


\section{FORT UNION FORMATION}

The claystone, siltstone, and sandstone beds of the Fort Union formation are inherently weak and easily eroded, hence materials from this formation are unsuitable for construction. In many localities, however, the cherry-red clinker resulting from the baking of the claystones and shales due to the burning of an underlying lignite bed is used for road metal. Because it normally breaks into small fragments and is not found in large enough pieces for use as flagstone, the material has not been used in the construction of homes.

\section{SAND AND GRAVEL}

Not all the huge deposits of gravel found in the area are suitable for construction. The Flaxville gravel; which crops out primarily in the western part of the area; contains a high percentage of siliceous pebbles in the form of opal; chalcedony, and tridymite. Concrete structures deteriorate rapidly where aggregates containing these materials are used with highly alkaline portland cement. Hence, if these reactive gravels are to be used in concrete construction, lowalkali cement is required.

Most gravel in the area is in the glaciofluvial deposits. These deposits contain only minute quantities of the deleterious materials and normally are well suited for construction purposes. A layer of calcium carbonate coats many of the pebbles and may reduce their binding effectiveness in concrete. This coating is not general, howover, and normally is restricted to pebbles in the lime-enriched zone.

All the gravel in the area is suitable for road metal. As most of the material is crudely sorted, some sizing is required. The highway. departments of both States have made use of these deposits.

RIPRAP

Glacial boulders constitute the only material in the area suitable for use as riprap. Over the years most of the farmers have gradually cleared their fields of these boulders, which have been heaped near section corners. Thus, in extensively cultivated areas heaps of unsorted boulders including many of a size suitable for riprap are usually available adjacent to most roads. The boulders consist of limestone, dolomite, granite, schist, gneiss, basalt, quartzite, and other types, and are as much as 10 feet in diameter, although the average is about 2 feet.

\section{WATER RESOURCES}

Ground water is more important in this area than surface water, as the streams within the broad outwash-floored valleys are narrow, sluggish, and stagnant during dry periods.

Such towns as Plentywood and Reserve obtain their water by shallow dug or drilled wells in the terraces and flood plain in the Big 
Muddy Creek valley. A detailed report on the ground-water resources of this area has been prepared by Vorhis (1949) and, therefore, no attempt is made to repeat that information. In general, the report suggests the following possible reservoirs: (1) Shallow and medium-depth permeable zones in the till, as well as a permeable zone at or near the base of the till; (2) channel outwash deposits, as well as ice-contact features such as kames, kame terraces, and eskers; (3) stream terraces and valley alluvium; and (4) the underlying Fort Union formation.

I am in agreement with all except the concept of permeable zones within the till. Wherever exposed, the till forms a solid mass devoid of widespread stratified deposits. Nowhere was an unconformity found within the till in this area, either as a soil profile or a layer of gravel. In several localities, however, gravel was noted cropping out locally below till. These deposits are very small and are interpreted as till-buried channel deposits (see p. 21). In most localities where till lies directly on the Fort Union formation, the contact is relatively tight and dry. In certain areas, however, a layer of Flaxville and early Quaternary (?) gravel lies between the till and the Fort Union formation; this may represent the lowest permeable zone. The heterogeneity of the till, its high clay content, and its compactness oppose the possibility of widespread lateral permeable zones within any one till sheet. If evidence does exist for widespread layers of proglacial gravels separating several till sheets, it was not observed in the field.

One explanation of the permeable zones in the till reported by Vorhis might be the presence of till-buried channels. It may be that ground water in wells passing through the till within these channels creates an erroneous impression of widespread permeable zones within the till (fig. 7).

\section{REFERENCES}

Alden, W. C., 1932, Physiography and glacial geology of eastern Montana and adjacent areas: U. S. Geol. Survey Prof. Paper 174.

Alpha, A. G., [no date], General geology of the sodium sulphate district near Grenora, North Dakota, in Lavine, Irvin, Report of sodium sulphate investigation: Federal Emergency Relief :Adm. Project for North Dakota, Work Division, S-F2-47, p. 7.

Ballard, Norval, 1942, Regional geology of Dakota Basin : Am. Assoc. Petroleum Geologists Bull., v. 26, no. 10, p. 1557-1584.

Bauer, C. M., 1912, Lignite in the vicinity of Plentywood and Scobey, Sheridan County, Mont.: U. S. Geol. Survey Bull. 541-H, p. 293-315.

1915, A sketch of the late Tertiary history of the upper Missouri River: Jour. Geology, v. 23, p. 52-58.

Beekly, A. L., 1912, The Culbertson lignite fleld, Valley County, Mont.: U. S. Geol. Survey Bull. 471-D, p. 319-358.

Binyon, E. O., 1951, North Dakota sodium sulfate deposits: U. S. Bur. Mines Prelim. Rept. 53.

1952, North Dakota sodium sulfate deposits: U. S. Bur. Mines Rept. Inv. 4880. 
Brown, R. W., 1949, Paleocene deposits of the Rocky Mountains and Plains: U. S. Geol. Survey Prelim. Map.

Calhoun, F. H. H., 1906, The Montana lobe of the Keewatin ice sheet: U. 8 . Geol. Survey Prof. Paper 50.

Cole, L. H., 1926, Sodium sulphate of western Canada ; occurrence, uses and technology : Canada Dept. Mines, Mines Branch, Rept. 646.

Collier, A. J., and Thom, W. T., Jr., 1918, The Flaxville gravel and its relation to other terrace gravels of the northern Great Plains: U. S. Geol. Survey Prof. Paper 108-J, p. 179-184.

Dawson, G. M., 1895, Glacial deposits of southwestern Alberta in the vicinity of the Rocky Mountains: Geol. Soc. America Bull., v. 7, p. 31-66.

Dawson, G. M., and McConnell, R. G., 1885, Report on the region in the vicinity of the Bow and Belly Rivers, Northwest Territory: Canada Geol. Survey, Repts. Prog. 1882-84.

Edwards, G. J., 1951, A preliminary report on the electrical resistivity survey at Medicine Lake, Montana : U. S. Geol. Survey Circ. 97.

Flint, R. F., 1955, Pleistocene geology of eastern South Dakota: U. S. Geol. Survey Prof. Paper 262.

Grossman, I. G., 1949, The sodium sulphate deposits of western North Dakota, a progress report: North Dakota Geol. Survey, Rept. Inv. 1.

Howard, A. D., 1947a, Evaluation of caliche-coated pebbles in glacial chronology [abs.] : Geol. Soc. America Bull., v. 58, no. 12, pt. 2, p. 1194-1195.

- 1947b, Glacial drifts of northeastern Montana and northwestern North Dakota [abs.] : Geol. Soc. America Bull., v. 58, no. 12, pt. 2, p. 1195.

1950, Till isopleth map of northeastern Montana and northwestern North Dakota [abs.] : Geol. Soc. America Bull., v. 61, no. 12, pt. 2, p. 1525.

Howard, A. D., Gott, G. B., and Lindvall, R. M., 1946, Late Wisconsin terminal moraine in northwestern North Dakota [abs.]: Geol. Soc. America Bull., $\nabla$. 57, no. 12, pt. 2, p. 1204-1205.

Johnston, W. A., and Wickenden, R. T. D., 1930, Glacial Lake, Regina, Saskatchewan, Canada : Royal Soc. Canada Trans., ser. 3, v. 24, sec. 4, p. 41-49.

Laird, W. M., 1946, The subsurface stratigraphy of the Nesson anticline: North Dakota Geol. Survey Bull. 21, p. 11-25.

Laird, W. M., and Towse, D. F., 1951, Stratigraphy of North Dakota with reference to oil possibilities: North Dakota Geol. Survey, Rept. Inv. 2.

Lavine, Irvin, [no date], Report of sodium sulphate investigations: Federal Emergency Relief Adm. for North Dakota, Work Division, Proj. S-F2-47, 38 p. [Mimeographed]

Lavine, Irvin, and Feinstein, Herman, 1936, Natural deposits of sodium sulphate in North Dakota: Am. Inst. Mining Met. Eng. Contr. 97.

Leonard, A. G., Babcock, E. J., and Dove, L. P., 1925, The lignite deposits of North Dakota : North Dakota Geol. Survey Bull. 4.

Levorsen, A. I. (ed.), 1941, Possible future oil provinces of the United States and Canada, a symposium: Am. Assoc. Petroleum Geologists Bull., v. 25, no. 8 , p. 1433-1586.

McConnell, R. G., 1885, Report on the Cypress Hills, Wood Mountain, and adjacent country: Canada Geol. Survey, Ann. Rept. 1, new ser. 1, v. 1, rept. C.

Meek, F. B., and Hayden, F. V., 1862, Descriptions of new Lower Silurian (Primordial), Jurassic, Cretaceous, and Tertiary fossils, collected in Nebraska Terr. . . . Acad. Nat. Sci. Phila. Proc. 1861, p. 415-447. 
Sahinen, U. M., 1948[?], Preliminary report on sodium sulphate in Montana : Mont. State Bur. Mines. [Reprinted in 1956 by Mont. State Bur. Mines and Geology, Inf. Circ. 11]

Saskatchewan Department of Natural Resources and Industrial Development, 1947, Natural resourcès of Saskatchewan : Regina, Sask., 152 p.

Smith, C. D., 1910, The Fort Peck Indian Reservation lignite field, Montana : U. S. Geol. Survey Bull. 381-A, p. 40-59.

Thom, W. T., Jr., and Woodring, W. P., 1921, Possible oil in northeastern Montana : U. S. Dept. Interior memo. for the press 9584.

Todd, J. E., 1914, The Pleistocene history of the Missouri River; Science, new ser., $\nabla .39$, p. $263-274$.

- 1923, Is the channel of the Missouri River through North Dakota of Tertiary origin?: Geol. Soc. America Bull., v. 34, no. 3, p. 469-493.

Townsend, R. C., 1950, Deformation of Fort Union formation near Lignite, North Dakota: Am. Assoc. Petroleum Geologists Bull., v. 34, no. 7, p. 1552-1564.

Townsend, R. C., and Jenke, A. L., 1951, The problem of the origin of the Max

-. Moraine: of North Dakota and Canada : Am. Jour. Scl., v. 249, no. 11, p. 842-858.

United States Federal Emergency Relief Administration, [no date], Report of sodium sulphate investigations: Proj. S-F2-47 for North Dakota.

United States Bureau of Mines, 1932, Analyses of Montana coals: U. S. Bur. Mines Tech. Paper 529.

Upham, Warren, 1904, Age of the Missouri River: Am. Geologist, v. 34, p. 80-87.

Vorhis, R. C., 1949, Progress report on the ground water hydrology of the Medicine Lake-Grenora area, Missouri-Souris Irrigation Project, Montana and North Dakota: U. S. Geol. Surrey Progress Rept., 88 p.

Willians, M. Y.; 1929, The physiography of the southwestern plains of Canada : Royal Soc. Canada Trans., ser. 3, v. 23, sec. 4, p. 61-79.

Williams, M. Y., and Dyer, W. S., 1930, Geology of southern Alberta and southwestern Saskatchewan: Canada Geol. Survey Mem. 163.

Witkind, I. J., 1952, The localization of sodium sulfate deposits in northeastern Montana and northwestern North Dakota: Am. Jour. Sci., v. 250, no. 9, p. 667-676. 


\section{INDEX}

Page

Acknowledgments

Agriculture.

Alamo, N. Dak

Alkabo, N. Dak

Alluvium

Altamont, S. Dak.

Altamont moraine. See Max moraine.

Antelope, Mont:

.....

Antelope sag, Montana

Assiniboine River, Canada

Big Muddy Creek, Mont

$26,28,33,34,35,37,38,44,54,58,61$

Big Muddy Creek channel.

Bowdoin do ne

Brush Lake, Mont. $27-34,44,57$

Brush Lake saline slough 45,46

Canadian Shield materials......... 15, 17, 27,37, 39, 52

Cedar Creek anticline.

Channel outwash deposits, age relations...... 26 description . . ............................... 20-23

Climate. ....................................... 7

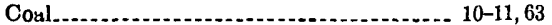

Coalridge, Mont_. . .......................... 15

Coalridge channel.................. 26, 39-43,50-51,61

Colluvium ............................... 40,54; chart

Cottonwood Creek channel.............. 26, 43, 50,61

Cottonwood Lake, N. Dak

Crevasse fillings. .

Culbertson, Mont

$23,25,36,49,53-54$

Dagmar channel.. 23, 28, 40, 41, 43, 44-45, 51-52, 57, $58,60,61,62$

Davis channel................................... 37-38

Dowd channel................................. 36

Dune sand.............................. 54; chart

Eskers. $23,25,47,49,52-53,62 ;$ pl. 7 ; chart

Flaxville gravel. $7,13,36,39,56$; chart

Flaxville Plain. $6,13,55-56$

Fort Union formation, drill-hole $\log$ exposures. $12-13$ geologic history $18,28,38-39$ Lebo shale member. (1)

L10-13

Ludlow member .

physical characteristics................... chart

Sentinel Butte member...................

stratigraphic section ..................... 10,12

Tongue River member. . . . . . .......... 9, 10, 12

Tullock member.
3 Fossils.

Page

Frold, Mont . . . .

Glacial and interglacial stages, early Wiscon-

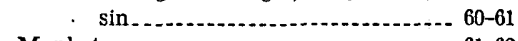

Mankato.................................. 61-62

middle Wisconsin.

pre-Wisconsin............................ 56-57

Glauber salt. See Sodium sulfate.

Gravels of early Quaternary age.... 13-16, 57; chart

Great Lignite group....................... 9

Grenora, N. Dak....... 23, 25, 46, 47, 50, 53, 58, 60, 68

Grenora channel................... 23, 44, 45, 47-48, 52

Grenora Lake 1, N. Dak . ................... 65

Grenora Lake 2, N. Dak.................. 65-66

Ground water...................... 30, 44, 71, 75-76

Hell Creek formation....................... 11, 55

Highways................................... 7

Homestead, Mont............................ 33

Horseshoe Lake, Mont. . .................... 53, 68,69

Ice-contact deposits, age relations............. $\quad 26$ description........................... 23-25; chart

Kame terraces . . . ........... 23, 25, 43, 45, 50-52; chart Kames....................... 23, 25, 48-49, 52, 62; chart Kamp No. 1 drill hole....................... 9

Kettle Lake, N. Dak ........................ 53 Kettles.............. 20, 25, 37, 39, 40, 44, 45, 46, 47, 48, 53

Lake Creek channel......................... 38, 58, 60

Linear channel. .............................. 38-39

Little Muddy Creek, N. Dak . . .

Location of area....

Max moraine............... 6, 8-9, 18, 23, 25, 44, 61-62

Medicine Lake, Mont... 23, 28, 30,32, 44, 45, 52, 54, 61

Missouri Plateau ............................... 6

Missouri River, preglacial course . ....... 44, 57-60

Nesson anticline............................... 8,8

No. 1 bench of Alden....................... 55

No. 2 bench of Alden..................... 56, 58,60

Otter Creek, Mont........................... 30

Plelstocene, geologic history .................. 56

Poplar, Mont.......... 58,60

Poplar anticline............. 8

Poplar River, Mont.......................... 38,61

Previous work .............................. 4 


\begin{tabular}{|c|c|}
\hline Page & Page \\
\hline Railroads.. & Stink Lake, N. Dak \\
\hline References.... & Stream-terrace deposits..... \\
\hline Reserve, Mont. ................ & \\
\hline iprap.................. & Till ridges_. \\
\hline & Till sheets, age relations. \\
\hline ind and gravel deposits. & physical properties... \\
\hline corio Valley, N. Dak & topographic expression..... \\
\hline Scorio Valley channel................. 43,46-47 & Twin Lakes, N. Dak \\
\hline 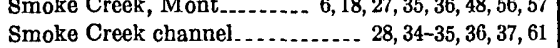 & \\
\hline dium sulfate, chemical origin .................. & Westby, Mont \\
\hline estimated reserves....................... $63-64$ & Williston, N. Dak.... \\
\hline Montana & Williston basin........ \\
\hline Dakota_...... $65-67$ & Wiota gravels \\
\hline$\ldots 70-74$ & Wolf Creek, Mont \\
\hline 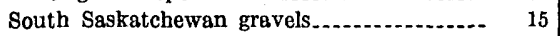 & - 28, 61 \\
\hline encer channel. & \\
\hline ady channel. & ik \\
\hline 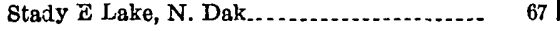 & Zahl channel................... \\
\hline
\end{tabular}

